Universidad Autónoma Metropolitana

Unidad Iztapalapa

División de Ciencias Sociales y Humanidades

Posgrado en Humanidades

Línea de Historia

\title{
TEATRO POPULAR EN LA CIUDAD DE MÉXICO EN LA PRIMERA MITAD DEL SIGLO XX Miguel Ángel Alemán Torres
}

Tesis que se presenta para obtener el grado de maestro en Humanidades

Línea de Historia

Director de tesis: Carlos Illades Aguiar

Lectores: Mario Barbosa Cruz y Federico Lazarín Miranda

29 de enero de 2013 


\section{AGRADECIMIENTOS}

En primer lugar quiero agradecer a mi familia por el apoyo y confianza que me tuvieron para la realización de esta tesis; a la Universidad Autónoma Metropolitana unidad Iztapalapa y a su cuerpo académico, por haberme formado como estudiante de nivel maestría; al Consejo Nacional de Ciencia y Tecnología, por haber financiado esta investigación; a mi director de tesis Dr. Carlos Illades Aguiar, por haberme orientado a lo largo del desarrollo de este trabajo; al Dr. Mario Barbosa Cruz, por sus valiosos comentarios que permitieron enriquecer esta investigación; al Dr. Federico Lazarín Miranda, por sus observaciones y su labor de coordinación de la línea de Historia del posgrado en Humanidades; al Dr. Ricardo Pérez Montfort, por sus invaluables comentarios que sirvieron para fortalecer este trabajo; a mis compañeros de posgrado y amigos en general que me ayudaron a sobrellevar esta etapa de mi vida profesional.

Espero que este trabajo sea una aportación al conocimiento humanista del país. 
ÍNDICE

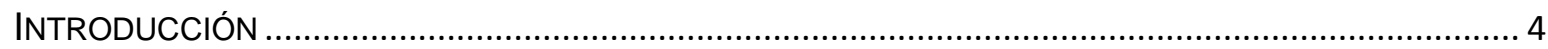

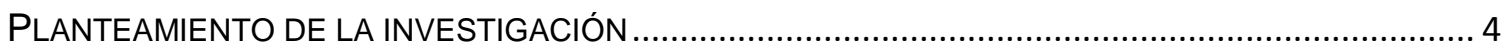

QUÉ ESCRIBIR SOBRE DIVERSIONES PÚBLICAS ............................................................... 7

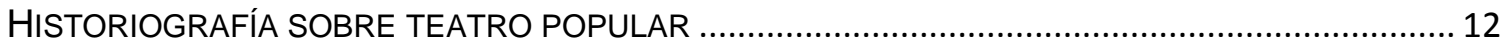

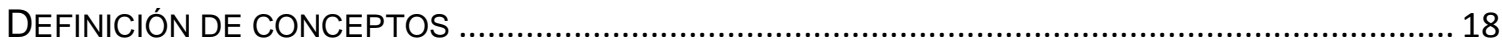

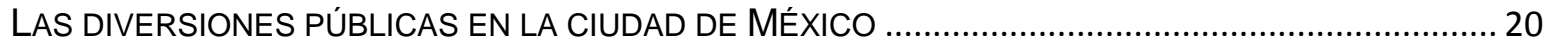

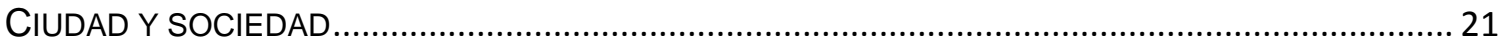

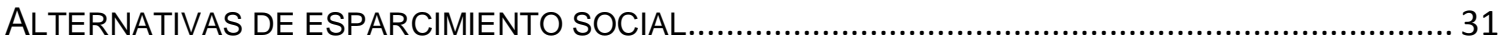

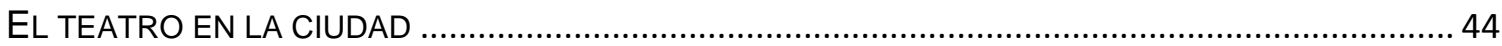

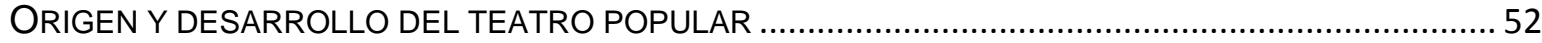

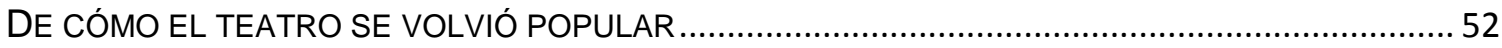

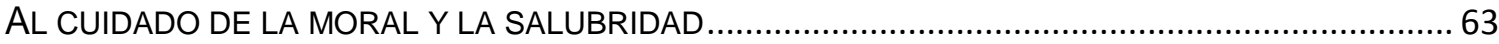

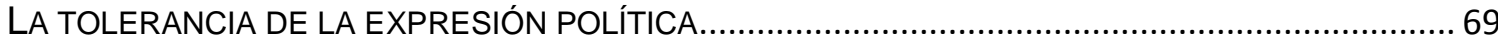

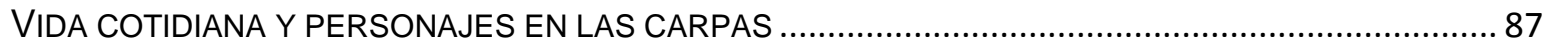

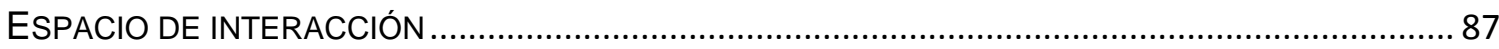

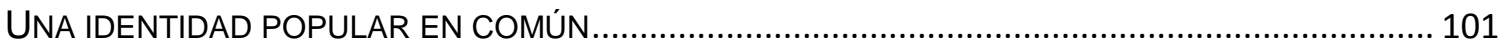

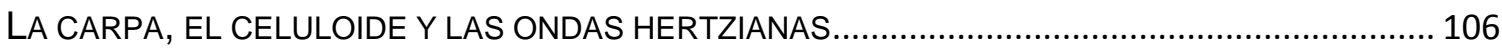

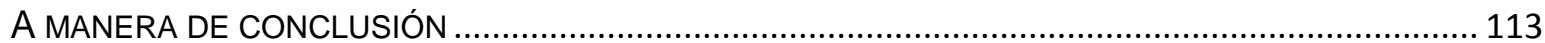

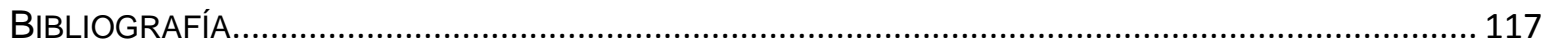




\section{INTRODUCCIÓN}

Quisiera comenzar este trabajo estableciendo los criterios de elección del tema, la delimitación temporal y espacial, así como los objetivos, hipótesis y la metodología empleada y algunos problemas que se presentaron para el desarrollo de la investigación.

Sobre diversiones públicas en la ciudad de México se han escrito diversos trabajos y en diferentes temporalidades, pocos en el periodo prehispánico, otros a partir de la etapa colonial, donde se retoma la mayor parte de las recreaciones europeas, y de esa manera evolucionan a lo largo del tiempo. Esta investigación se centra en las diversiones públicas durante la primera mitad del siglo XX, específicamente del teatro popular desarrollado en la ciudad de México.

En otro apartado de esta introducción se hace un balance sobre algunos trabajos que se han escrito sobre diversiones públicas en la ciudad de México. Retomaré a diversos autores que han abordado la temática desde diferentes concepciones, espacios y temporalidades. Tomaré como ejes de análisis los tipos de diversiones que estudian, las fuentes que manejan, la metodología y herramientas que utilizan y la forma en que cada autor propone algo innovador.

Asimismo hablaré sobre la historiografía del teatro popular para obtener un panorama general y las formas como se han abordado. No solamente es dar cuenta de lo que se ha investigado sobre el tema, sino trazar una propuesta sobre lo que hace falta trabajar.

Por último, considero necesario realizar una definición de conceptos que hará más entendible la lectura del texto en su desarrollo, ésta se hará según los géneros teatrales, las modalidades de accesibilidad por parte de población y la definición de los espacios mismos donde se representan las obras.

\section{Planteamiento de la inVestigación}

El haber escogido esta temática surgió por el interés de analizar una de las opciones de recreación que tenía la sociedad capitalina durante tres momentos en la primera mitad del siglo XX. El periodo corresponde desde la última etapa del 
Porfiriato, donde se muestra una relativa paz social y no se podía hacer la más pequeña crítica al régimen; continúa con el rompimiento de los cánones establecidos en el teatro popular, que inicia simbólicamente en 1909 con la primer revista política de éxito por su contenido, México Nuevo, que antecede al movimiento armado y al inicio de la proliferación de obras de tinte político donde se podían narrar los sucesos del gobierno desde una manera satírica; y concluye en 1944 con el declive total del teatro político acontecido por la falta de libertad de expresión, y el gusto por otras diversiones como el teatro de variedades, la revista romántica, la radio y el cine, además de que para entonces la mayoría de cómicos de carpa ya se habían integrado a la industria cinematográfica.

La delimitación espacial de la investigación se centra en la ciudad de México, ya que fue la ciudad que tuvo mayor vida teatral, las demás generalmente sólo fueron receptoras de lo que se representaba en la capital.

La investigación tiene como objetivo analizar porqué surge el teatro popular, bajo qué acontecimientos sociales y políticos se lleva a cabo, cuál era el motivo por el que la población gustaba de este entretenimiento, y las causas de la decadencia del género.

La primera hipótesis se centra en que el teatro de revista fue un medio de esparcimiento preferido por la sociedad capitalina, que además de entretener, servía de medio de comunicación de los principales acontecimientos políticos del momento, que se trataban de manera satírica, situación que el público demandaba y era factor determinante para el éxito de las obras.

La segunda hipótesis es que muchos actores de teatro de revista fueron acaparados por la industria cinematográfica y radiofónica, lo que desembocó en el declive del teatro popular; es cierto que muchos artistas alcanzaron fama al incursionar en el cine y la televisión, sin embargo no fue una regla general, hubo excepciones, ya que algunos actores que fueron famosos dentro de la carpa no lograron éxito en la industria cinematográfica, o simplemente no quisieron incursionar en este tipo de espectáculo porque perdían su interacción con el público. 
La tercera hipótesis es que dentro de las carpas y el teatro de revista se tuvo amplia libertad de expresión para tratar los asuntos políticos y que los mismos actores en el cine ya no gozaron de la misma libertad, ya que la industria cinematográfica estaba controlado por el aparato estatal, además de que los actores estaban dentro de los sindicatos, que a su vez eran parte del aparato corporativo que controlaba el gobierno para tener bajo control a los sectores populares; esto desemboca a que se regularan los argumentos cinematográficos, por lo que se despolitiza el discurso que tenía el actor dentro de la carpa.

La cuarta hipótesis consiste en evidenciar una relación íntima entre los actores y los espectadores, a tal grado que se puede considerar que el teatro popular mexicano no pudo haber sido constituido sin esta coacción entre las dos partes, algo que en la radio y el cine se pierde completamente, ya que en estos medios los espectadores ya no pueden interactuar con los artistas, y a la vez se genera el desarrollo de la industria del entretenimiento, que ofrece una recreación a partir del radio, el cine y la televisión, donde ya no existe la interacción personal entre público y actor.

En la investigación se utilizaron fuentes primarias, principalmente las del Archivo Histórico del Distrito Federal (AHDF), en el Ramo de Diversiones Públicas, donde se encuentra información valiosa correspondiente a los permisos para establecer teatros, normas sanitarias, sanciones y modificaciones a leyes concernientes a este tipo de espectáculos. Asimismo la información hemerográfica correspondiente a espectáculos y escándalos políticos acontecidos en los teatros arroja datos importantes para esta investigación. También se trataron de encontrar los libretos de las obras más representativas de teatro de revista en el fondo de Propiedad Artística y Literaria del AGN, sin embargo el resultado no fue del todo provechoso, ya que son escasas las obras registradas que fueron de utilidad. Por su parte, las fuentes hemerográficas fueron de gran ayuda para comprender el ambiente social y artístico de los teatros, y sobre todo para darnos cuenta de su declive a partir de la lectura de los críticos en la década de 1930 en los semanarios ilustrados. 
También aproveché las fuentes fotográficas que evidencian el estado de físico y la ubicación de algunos teatros de carpa, así como de su interior donde podemos observar el tipo de personas que asisten a los espectáculos y la escenografía precaria donde representan su papel los actores. Estas imágenes no son utilizadas como simple ilustración del texto, sino como elementos de los cuales se puede extraer información. De la misma manera quedan como testimonio los carteles y programas de mano donde se anunciaban los espectáculos de determinados teatros, la mayoría de ellos son grabados que, además de contener un alto valor estético, nos dejan ver las relaciones que tenían ciertos actores en escenarios específicos.

En el trabajo de Socorro Merlín ${ }^{1}$ se encuentran testimonios de personajes de carpa que resultan de gran utilidad. Asimismo es rescatable la entrevista realizada a Adalberto Martínez El Resortes, por parte del Archivo de la palabra del Instituto Mora; y la realizada a Jesús Martínez Palillo, contenida en una tesis de licenciatura en Ciencias de la Comunicación. ${ }^{2}$

Las demás fuentes secundarias, como las biografías, son importantes porque ofrecen información específica de algunos personajes y acontecimientos del momento. Otros trabajos se evocan a investigaciones que tangencialmente retoman las diversiones públicas y los espectáculos teatrales, de los cuales también se recopila información de gran valor.

\section{QUÉ ESCRIBIR SOBRE DIVERSIONES PÚBLICAS}

Mencionaré algunos trabajos que diversos autores han realizado sobre las diversiones públicas para ofrecer un panorama de cómo han retomado ciertos enfoques historiográficos en diferentes territorios y temporalidades.

Se debe abordar el problema desde diversos escenarios sociales: los empresarios, los intérpretes y el público, como partes integrales de una estructura de las diversiones públicas, es decir, un análisis estructuralista. De ahí que la investigación cultural sobre las diversiones públicas debe tomar en cuenta las

\footnotetext{
${ }^{1}$ Socorro Merlín, Vida y milagros de las carpas. La carpa en México 1930-1950, INBA-CITRU, México, 1995.

2 Sebastián Armando González de la Vega Alcántara, Jesús Martínez Rentería "Palillo" en el periodo 19521964, tesis para optar por el grado de Licenciado en Ciencias de la Comunicación, UNAM, México, 2001.
} 
relaciones que se guardan entre los diferentes agentes, para reconocer la diversidad de puntos de vista sobre el modo en que las múltiples partes perciben y entiendan a su contraparte. Se deben de analizar de manera interconectada y confrontada para enriquecer el contexto sociocultural, considerando que las diversiones públicas, en un lugar y determinado tiempo, se renuevan o surgen en competencia por los públicos; lo que implica que el estudio del complejo epistemológico deba abordarse no como una descripción de estados inalterables, sino como procesos en constante reorganización y recomposición. Asimismo el estudio no se debe limitar a un análisis tajante entre la cultura de la élite y la de las clases populares, sino observar las relaciones que guardan entre sí los estratos sociales y la manera cómo se generan causas y efectos, expresadas en las diversiones públicas.

En cuanto al texto de Juan Pedro Viqueira Albán, ${ }^{3}$ quisiera retomar lo que apunta en el prefacio, ya que es una manera de conocer las causas que lo determinaron a escribir su trabajo y cómo lo hizo. Indica que se vio motivado al notar que los valores morales y las pautas de conducta cambian drásticamente de generación en generación. Él menciona que en un principio quiso abarcar el relajamiento de las costumbres, lo cual le pareció muy amplio para ser abordado en su totalidad, por lo que decidió ceñir su estudio específicamente hacia las diversiones públicas como los toros, el teatro, las diversiones callejeras y el juego de pelota, específicamente en la ciudad de México.

En lo que corresponde a la temporalidad, argumenta que encontró mucha más información a partir de la segunda mitad del siglo XVIII y decide incluir también el periodo de la guerra de independencia, deteniéndose en la consumación de la misma. De esta manera hay que considerar que es necesaria una delimitación temática, temporal y espacial para poder realizar un análisis eficaz.

En cuanto a las fuentes que retomó para realizar esta investigación, Viqueira menciona que consultó principalmente reglamentos, bandos, decretos, informes de autoridades y solicitudes de licencias. El autor estuvo consciente que

\footnotetext{
3 Juan Pedro Viqueira Albán, ¿Relajados o reprimidos? Diversiones públicas y vida social en la Ciudad de México durante el Siglo de las Luces, FCE, México, 1987.
} 
estos documentos plasman sólo la visión que los gobiernos virreinales tenían de las diversiones públicas, evidenciando que los archivos guardan la memoria de las clases dominantes, por lo que él las utiliza para realizar una visión crítica y acercarse hacia la contraparte, que son las clases populares.

El trabajo de Eduardo Flores Clair, ${ }^{4}$ enfocado a las diversiones públicas en la ciudad de México de 1920 a 1940, menciona que durante la lucha armada los espectáculos en la ciudad disminuyeron, por lo que en este texto se abordan las diversiones públicas desde el periodo postrevolucionario, retoma principalmente las representaciones escénicas, las corridas de toros y los eventos deportivos; las proyecciones en cinematógrafos sólo las menciona pero no las aborda, no explica por qué.

También estudia las diversiones deportivas como el beisbol, futbol y box, en donde el autor pone en claro la importancia que tuvieron los empresarios para dar impulso a estas actividades mediante grandes inversiones para infraestructura deportiva; pone como ejemplo la construcción de la Ciudad de los Deportes. Considero que lo más destacable de este texto es que nos da a entender cómo las diversiones públicas, más allá de considerarlas necesarias para la reproducción social, se convierten en elementos para la reproducción de capital, ya que los empresarios de los distintos entretenimientos se preocupan por acaparar la mayor cantidad de público.

Otro trabajo interesante sobre las diversiones públicas es el ensayo que presenta María Dolores Lorenzo Río ${ }^{5}$ sobre la segregación social y espacial acorde a las diversiones públicas en la ciudad de México en el periodo comprendido de 1810 a 1910. Cabe destacar que este texto nace a partir de reflexionar sobre los centenarios que se festejan en México del inicio de las luchas armadas (Independencia y Revolución), con lo cual surge el interés de analizar

\footnotetext{
4 Eduardo Flores Clair, "Diversiones públicas en la ciudad de México, 1920-1940", en Historias, no. 27, octubre 1991-marzo 1992, pp. 163-169.

${ }^{5}$ María Dolores Lorenzo Río, "Entre el vicio y el beneficio. Segregación social y espacios de entretenimiento en la ciudad de México, 1810-1910", en Mario Barbosa Cruz y Salomón González (coordinadores), Problemas de la urbanización en el Valle de México, 1810-1910. Un homenaje visual en la celebración de los centenarios, UAM, México, 2010, pp. 227-262.
} 
cómo se divertía la población de la ciudad de México durante este periodo de cien años.

Lo destacable de este trabajo es el análisis territorial que realiza a partir de la información sistematizada de 500 licencias consultadas en el Archivo Histórico del Distrito Federal, lo cual demuestra la segregación espacial en torno a las diversiones públicas de las diferentes clases sociales de la ciudad. Asimismo argumenta que a finales del siglo XIX, con la explosión demográfica y la urbanización, la segregación espacial fue más evidente dando como resultado que las clases populares tuvieran sus espacios de entretenimiento como los jacalones, circos y juegos populares hacia el norte, oriente y sur de la ciudad, mientras que los de la élite, como salones y casinos, se ubicaron al poniente.

En su trabajo, cabe destacar la importancia del uso de Sistemas de Información Geográfica e imágenes (litografías, fotografías y planos), ya que de esta manera nos ofrecen un panorama visual sobre los fenómenos sociales en la ciudad de México. Además María Dolores Lorenzo también hace uso de herramientas cuantitativas cuando presenta una muestra representativa del número de permisos para diversiones públicas provisionales y establecidas de 1810 a 1909. El uso de herramientas cuantitativas y cartográficas puede ser muy útil siempre y cuando las usemos con una visión crítica.

La aportación de Ricardo Pérez Montfort también es importante para la comprensión de las diversiones públicas en la ciudad de México, uno de sus trabajos, enmarcado en el contexto de otros ensayos sobre la cultura en México entre 1850 y $1950^{6}$ nos lleva de la mano a apuntes sobre cómo se divertía la población capitalina al terminar el siglo XIX y empezar el XX. Comienza haciendo referencia al contexto urbano de la ciudad, así como a las características sociales de la población, con sus respectivos contrastes entre la elite porfiriana y las clases bajas. De esta manera nos introduce a las preferencias y limitaciones de esparcimiento de la población según sus posibilidades. Hace mención de las principales diversiones como los bailes, el circo, el teatro, el cinematógrafo, la

\footnotetext{
${ }^{6}$ Ricardo Pérez Montfort, “Circo, teatro y variedades. Diversiones públicas en la ciudad de México a la vuelta del siglo Xx", en Cotidianidades, imaginarios y contextos: ensayos de historia y cultura en México, 1850-1950, CIESAS, México, 2008, pp. 79-114.
} 
fiesta brava, los globos aerostáticos, las peleas de gallos, las carreras de caballos, los casinos, paseos en bicicleta, carreras de automóviles, elevación en aeroplanos, frontón, cricket, polo, box y futbol.

La obra de Maya Ramos Smith es otro de los trabajos que han abordado las diversiones públicas, ella lo hace sobre los artistas callejeros e itinerantes en el periodo colonial, ${ }^{7}$ de la cual aporta información valiosa sobre el tipo de recreaciones alternativas y marginales que formaron parte importante en la cultura popular de la sociedad novohispana, de lo cual existe muy poco escrito. Nos lleva de la mano por este tema a partir de diversos aspectos como: antecedentes prehispánicos y europeos, reglamentación, censura, propuesta artística y la cuestión social. Este trabajo nos aporta indicios sobre los orígenes de las diversiones populares, lo cual resulta importante para comprender la situación marginal por la que han pasado los artistas callejeros, muchos de ellos de circo que de cierta manera se relacionan con los jacalones o carpas de los que nos ocuparemos en esta investigación.

Es importante darse cuenta que los autores no retoman las diversiones públicas de una manera aislada, sino que las ubican en un contexto social, político y cultural de sus respectivos espacios. Una constante que encontré en la mayoría de los trabajos es que sus fuentes son básicamente los archivos históricos en los ramos de licencias, sanciones y problemas policiales lo cual demuestra cómo las autoridades querían tener un registro, control y represión de las actividades recreativas de las clases populares, de las cuales se puede obtener información valiosa para tratar de comprender cómo eran las diversiones públicas en determinadas temporalidades.

Asimismo descubrí que podemos retomar diferentes metodologías para realizar nuestra investigación, como herramientas visuales, antropológicas o métodos cuantitativos y cartográficos. En fin, con base en las corrientes historiográficas y metodologías, podemos retomar de manera crítica lo útil de cada una para aportar algo innovador en la historiografía.

\footnotetext{
${ }^{7}$ Maya Ramos Smith, Los artistas de la feria y de la calle: espectáculos marginales en la Nueva España (19591822), conACULTA, México, 2010.
} 


\section{HistoriogRAFÍA SOBRE TEATRO POPULAR}

Sobre el teatro popular en la ciudad de México existen diversos trabajos, cada uno de ellos con su particular punto de vista. Habrá que mencionar que el teatro popular es referido de diferentes formas dentro de la historiografía. Los grandes cronistas de teatro como Rodolfo Usigli, Luis Reyes de la Maza, Armando de Maria y Campos, Olavarría y Ferrari, entre otros, hacen referencia.

Luis Reyes de la Maza en su obra ${ }^{8}$ propone analizar 100 años de teatro en México a partir de 1810 a 1910, su investigación aporta datos relacionados con los grandes actores, obras y teatros más importantes del país sin hacer gran referencia a los teatros de barrio y circos que existieron en la capital.

Por su parte, Pedro Granados, quien aparte de espectador fue amigo de artistas, empresarios, gritones, vendedores y músicos del medio, conoció directamente el ambiente de las carpas en la década de 1930. Conservó miles de programas, fotografías, recortes de periódico, autógrafos y boletos de las funciones. Nos ofrece sus anécdotas en ese ambiente, lo cual también es de gran valor para obtener datos convenientes a este trabajo. ${ }^{9}$ El propio Pedro Granados escribe al respecto:

Pocos documentos hay de ese tiempo. Las carpas no eran visitadas por los críticos, ni por los fotógrafos, quizás algún bohemio de la talla de Javier Luna, Rivas Larrauri o de Ortega y otros desbalagados periodistas, llegaban hasta los malolientes camerinos. Sin embargo, de nuestro archivo particular de los propios artistas, presentaremos fotos, programas y recortes que darán fe de la época a que nos referimos. ${ }^{10}$

Su trabajo recae de principios del siglo Xx hasta finales de la década de 1930, fecha que él considera el declive del espectáculo de carpa, según él por el engrandecimiento y modernidad de la ciudad de México, el tránsito y las nuevas avenidas que ya no permitieron que se instalara una carpa más.

\footnotetext{
${ }^{8}$ Luis Reyes de la Maza, Cien años de teatro en México (1810-1910), SEP, México, 1972. y Circo, maroma y teatro, UNAM, México, 1985.

${ }^{9}$ Pedro Granados, Carpas de México. Leyendas, anécdotas e historia del teatro popular, Editorial Universo México, México, 1984.

${ }^{10}$ Ibidem, pág. 52.
} 
Socorro Merlín realizó una importante investigación donde retoma 20 años (1930-1950) sobre el teatro de carpa en México, menciona que el tema ha sido retomado sólo para hacer alusión a la desaparición del género revisteril en México o como paradigma de lo negativo del teatro. ${ }^{11}$ En su opinión, los académicos niegan el valor estético de la carpa y no logran concebirla como parte del teatro. Además menciona que la carpa sólo ha sido mencionada de forma anecdótica en artículos periodísticos y mesas redondas.

Su trabajo es de gran relevancia porque además de su visión de investigadora teatral nos ofrece un panorama con enfoque sociológico, antropológico, histórico y psicológico, además de recopilar diversas entrevistas que realizó a actores que fueron parte de las carpas.

De su investigación se generó un fondo documental, "La carpa en México", en el Centro de Investigación Teatral Rodolfo Usigli (CITRU) donde se puede consultar valioso material documental, hemerográfico, fonográfico y fotográfico sobre las carpas en México.

Debido a la recopilación de ensayos enfocados a la identidad nacional en las expresiones artísticas, ${ }^{12}$ se publicó el trabajo de Carlos Pérez Bazán que aborda la identidad nacional en el teatro popular durante la primera década del siglo XX, lo cual es importante debido a que considera al teatro popular como elemento que ayuda a entender el término de nación visto desde abajo, ya que en dicho ensayo afirma que "la historia del teatro en el periodo revolucionario de 1910 sólo ha sido documentada en una pequeña parte y con mayor regularidad se ha dado preferencia al teatro "serio". ${ }^{13}$ Menciona que probablemente esto se deba a que existen mayores fuentes sobre ese teatro, y que el teatro popular sólo ha sido tomado en cuenta desde una perspectiva de curiosidad folclórica.

Él se enfoca a la primera década del siglo $\mathrm{xx}$, sin embargo resulta interesante la clasificación que realiza por etapas del teatro de género chico de la

\footnotetext{
${ }^{11}$ Socorro Merlín, Vida y milagros de las carpas, op. cit., pág. 9.

${ }^{12}$ Raúl Bejar y Silvano Héctor Rosales (coordinadores), La identidad nacional mexicana en las expresiones artísticas. Estudios históricos y contemporáneos, UNAM-Plaza y Valdés, México, 2008.

${ }^{13}$ Carlos Pérez Bazán, "La identidad nacional en el teatro popular durante la primera década del siglo xx", en Raúl Bejar y Silvano Héctor Rosales (coordinadores), La identidad nacional mexicana en las expresiones artísticas. Estudios históricos y contemporáneos, UNAM-Plaza y Valdés, México, 2008, pág. 45.
} 
siguiente manera: la primera que va desde la última década del siglo XIX hasta los primeros años del $x x$, que se caracteriza por tratar de establecer un teatro netamente nacional a partir de la copia de los modelos europeos; la segunda etapa la clasifica de 1909 a 1917, que se caracteriza por el teatro político que detona durante el conflicto armado; la tercera etapa que establece entre 1916 y 1918, donde se reduce la sátira política, que atribuye a que el público se encontraba fastidiado de noticias de guerra y miseria; y la cuarta etapa que determina su inicio también en 1916 con el auge de la cocottería y el folclor, y concluye en 1924, fecha en que llegó a México la moda del Ba ta clán, donde también se retoma el chiste político. ${ }^{14}$ Retoma esta división a partir de los comentarios que hicieron los cronistas de época respecto a los estrenos más notables en cada momento, y manifiesta que un análisis completo sobre el tema se tendría que realizar hasta bien entrada la década de 1950.

El trabajo que aportó Armando Maria y Campos sobre el teatro de género chico en México ${ }^{15}$ es indispensable para esta temática, sus crónicas de teatro dejaron testimonio de lo acontecido dentro del espectáculo durante la primera mitad del siglo $x x$ debido a que el autor vivió inmerso en el ambiente teatral y conservó valioso material al respecto. En su trabajo aporta datos sobre las principales obras representadas en la época, los argumentos, fragmentos de los actos y biografía de autores, actores y críticos, nunca desligados de los acontecimientos políticos de la época. También de importancia es su obra sobre el teatro Principal ${ }^{16}$ enfocado a las tandas representadas y a las obras de José F. Elizondo, en ella nos ofrece información minuciosa sobre lo acontecido dentro del teatro en cuestión de actores, autores y circunstancias sociales de la época de auge de aquel gran teatro.

Otro gran trabajo inmerso en la historiografía del teatro popular en México es el que realizó Alejandro Ortiz Bulle Goyri sobre los orígenes y desarrollo del teatro de revista, en donde argumenta que "Mucho se ha escrito y hablado y

\footnotetext{
${ }^{14}$ Ibidem, pág. 47.

${ }^{15}$ Armando de Maria y Campos, El teatro de género chico en la Revolución mexicana, CONACULTA, México, 1996.

${ }^{16}$ Armando de Maria y Campos, Las tandas del Principal, Diana, México, 1989.
} 
festinado sobre espectacularidad y la comicidad del teatro de revista en México, pero poco se ha estudiado con la debida profundidad, pues ha sido sistemáticamente despreciado, durante décadas, por los creadores teatrales "serios" que procuraban impulsar un teatro "dramático" civilizado. El teatro de revista, desde la perspectiva de la cultura dominante o de élite, había perdido su validez y, en consecuencia, su importancia artística como objeto de estudio o modelo de creación en la escena mexicana del siglo XX en décadas ulteriores. Poco valor se le asignaba dentro del contexto de la conformación del teatro moderno mexicano, pues no respondía a los modelos de teatro de arte, ni mucho menos a los postulados en Europa desde siglos atrás. El teatro de revista significaba atraso y vulgaridad y nada tenía que ver con el arte. ${ }^{17}$ Sin embargo, el autor comenta que en la actualidad hay una mirada menos prejuiciosa para este estilo de teatro, por lo que han existido esfuerzos por parte de diversos autores para abordar la temática.

Su aportación es importante ya pone de manifiesto las diferencias y similitudes entre el teatro de carpa y el teatro de revista, que en la mayor parte de la historiografía no queda muy claro la relación que guardan ambos, uno como espacio y el otro como género teatral. La temporalidad que abarca es de 1869, con el origen de los jacalones que más tarde fueron conocidos como carpas, hasta 1953, llegada la modernidad de la posguerra impulsada por el régimen de Miguel Alemán. Aborda 80 años de teatro de revista en donde realiza apuntes concretos de los orígenes, principales características, acontecimientos más importantes y principales autores y autores.

Carlos Monsiváis, como gran intelectual y conocedor de la cultura mexicana durante el siglo XX, escribió también sobre el teatro, ${ }^{18}$ y en ese marco se interesó en realizar apuntes sobre el teatro popular, en donde nos narra a partir de su redacción característica, las principales anécdotas acontecidas en el medio, tanto de las obras, como de los personajes, autores, espectadores y vida cotidiana. Asimismo son rescatables sus ensayos anecdóticos sobre el medio de los

\footnotetext{
${ }^{17}$ Alejandro Ortiz Bullé Goyri, “Orígenes y desarrollo del teatro de revista en México (1869-1953)", en David Olguín (coordinador), Un siglo de teatro en México, CONACULTA-FCE, México, 2011, pág. 41.

${ }^{18}$ Carlos Monsiváis, Historia mínima. La cultura mexicana en el siglo XX, El Colegio de México, México, 2010.
} 
espectáculos, ${ }^{19}$ de los cuales se rescata para esta investigación lo relacionado con Cantinflas, visto como personaje modelo que representa el ambiente arrabalero de los teatros de carpa.

El Museo Nacional de Culturas Populares realizó una exposición llamada "El país de las tandas" en donde se exhibieron diversos objetos y documentos relacionados con el teatro de revista en México. El resultado fue la edición de materiales sonoros con música de revista, una recopilación de libretos y un acervo de fotografías, además de un libro coordinado por Alfonso Morales, ${ }^{20}$ donde a manera de relato nos platica de los principales acontecimientos en el teatro de revista entre 1900 y 1940, los autores, actores y obras más importantes y una serie de fotografías y programas.

Las canciones del teatro de revista también han sido objeto de antología, como es el caso de la compilación de Jorge Miranda, ${ }^{21}$ donde se pueden apreciar diversas letras reunidas a partir de los cancioneros del impresor Vanegas Arroyo y los Cancioneros Picot, de las canciones que sonaban en el teatro de revista aproximadamente de 1900 a 1940. Dicho trabajo cuenta con la valiosa introducción de Alfonso Morales.

Pablo Dueñas realizó un trabajo muy interesante sobre las divas en el teatro de revista donde aporta información valiosa a partir de la revisión de su propio acervo documental y fonográfico. Si bien su estudio se centra en el análisis de las divas que participaron en el teatro frívolo, también aporta los datos más importantes sobre el espectáculo revisteril desde enfoques históricos, políticos y artísticos entre 1900 y 1940, con una gran cantidad de elementos gráficos de alto valor, como fotografías, caricaturas y programas de mano. El periodo lo consideró desde que la revista comenzó su popularidad hasta su decadencia por el advenimiento del cine y la censura, al mismo tiempo que las divas transitaron hacia otro tipo de espectáculos.

\footnotetext{
${ }^{19}$ Carlos Monsiváis, Escenas de pudor y liviandad, Grijalbo, México, 1988.

${ }^{20}$ Alfonso Morales, El país de las tandas. Teatro de revista, 1900-1940, CONACULTA, México, 1984.

${ }^{21}$ Jorge Miranda (compilador), Del racho al bataclán. Cancionero del teatro de revista, 1900-1940, México, Museo Nacional de Culturas Populares, 1984.
} 
En otro trabajo, pablo Dueñas junto con Jesús Flores y Escalante aportan a una compilación sobre teatro mexicano su particular trabajo sobre teatro de revista. ${ }^{22}$ En él realizan un balance general sobre este género en el periodo de 1904 a 1936, enfatizando las características del teatro de revista y sus antecedentes históricos. Clasifican al género en costumbrista, político, frívolo, de evocación y musical. Asimismo analizan cuatro revistas más representativas de los diferentes subgéneros: Chin-chun-chan, El país de la metralla, Mexican rataplán y Amor de mis amores. Su trabajo es acompañado por imágenes relevantes de autores, divas y actores. La importancia de su trabajo radica en la claridad para definir a este género teatral, así como la contextualización social y política de las obras más representativas.

Susan E. Bryan en su trabajo sobre teatro popular durante el Porfiriato, ${ }^{23}$ hace un importante análisis de cómo el teatro "culto" se popularizó por medio de la introducción de las tandas, o sea la oferta del teatro pagado por horas, lo cual dio acceso a la mayor parte de la población al teatro por un costo equivalente al que pagan en los jacalones. Esto es un punto importante ya que si no se llega a entender bien la masificación del teatro, no podría quedar claro el concepto y desarrollo del género chico mexicano.

La editorial Clío ha publicado algunos trabajos que retoman la historia de personajes cómicos que formaron parte de la industria cinematográfica y televisiva que tuvieron sus inicios dentro de las carpas, como Mario Moreno Cantinflas ${ }^{24}$ y Joaquín Pardavé. ${ }^{25}$ Asimismo produjeron un documental llamado Los teatros del pueblo, donde hacen una narración iconográfica a partir de películas de la época de oro del cine mexicano sobre el surgimiento, desarrollo y decadencia de las carpas. Tanto en los dos trabajos publicados como en el documental, su mayor aportación es la investigación iconográfica ya que muestran fotografías y videos

\footnotetext{
${ }^{22}$ Pablo Dueñas y Jesús Flores y Escalante, “Teatro de revista (1904-1936)” volumen xx, en Teatro mexicano. Historia y dramaturgia, México, CONACULTA, 1995.

${ }^{23}$ Susan E., Bryan, "Teatro popular y sociedad durante el Porfiriato", en Historia Mexicana, Vol. 33 no. 1, julsep, 1983, El Colegio de México, pp. 130-169.

${ }^{24}$ Miguel Ángel Morales, Cantinflas. Amo de las carpas, Clío, México, 1996.

${ }^{25}$ Josefina Estrada, Joaquín Pardavé. El señor del espectáculo, Clío, México, 1996.
} 
de gran valor. Sin embargo, hace falta un análisis más crítico y profundo sobre la temática.

Estos son los trabajos realizados que abordan la temática del teatro de revista en México. Es imprescindible hacer un análisis de ellos para poder establecer una línea de trabajo a seguir sobre lo que falta sobre el tema. Si bien la mayoría de ellos aporta datos valiosos relacionados con los actores, las obras y los principales acontecimientos, hace falta profundizar en el tema a partir de las relaciones sociales que se generaron en los contextos políticos; además de la transición de los actores hacia otro tipo de entretenimientos, con el respectivo rompimiento de la relación público-actor; así como el aprovechamiento de la cultura popular por parte de los gobiernos posrevolucionarios para dar paso a la industria del entretenimiento cuyo desarrollo ha tenido gran impacto y penetración en la sociedad actual. Por lo tanto, espero que esta investigación aporte algo innovador a la historiografía del teatro popular en México.

\section{DEFINICIÓN DE CONCEPTOS}

Antes de entrar al desarrollo del tema es imprescindible definir una serie de conceptos para ayudar a leer con más claridad el texto. En la historiografía existente no hay una definición clara sobre el teatro popular. Muchas veces se piensa que el teatro de revista es lo mismo que las carpas y las tandas, lo cual es falso, ya que el primero corresponde a un género teatral, las segundas son lugares específicos donde se llevaban a cabo una diversidad de entretenimientos, y las terceras son una forma de vender el espectáculo, es decir, por horas, que podían ser tanto en teatros establecidos como en carpas. Por lo tanto haré una definición general de algunos conceptos, tomando en cuenta los espacios físicos, géneros teatrales y modalidades de acceso, de los que se hablará en el desarrollo de esta investigación para que sea más entendible su lectura.

Uno de los conceptos clave es la zarzuela, que corresponde a una forma de música teatral o género musical escénico surgido en España con partes instrumentales, partes vocales y partes habladas, si es de un acto se considera de género chico y si es de más actos, de género grande. 
El teatro costumbrista es una variante de la zarzuela cuyo argumento se enfoca a enaltecer los valores nacionales, por medio de trajes y escenarios típicos y folclóricos, y personajes populares, como charros, chinas poblanas o indígenas. Otro género fue el teatro frívolo o sicalíptico, cuyo contenido era sensual y erótico, que fue muy criticado por los moralistas e intelectuales durante el Porfiriato. Estos dos géneros se desarrollaron antes de la lucha armada de principios del siglo $\mathrm{XX}, \mathrm{y}$ no contenían crítica política alguna, debido a la falta de libertad de expresión durante el régimen de Porfirio Díaz.

Una vez caído el Porfiriato, surgió el teatro político, cuyas obras trataban los temas políticos y sociales del país de una forma satírica. $Y$ va de la mano del teatro de revista, que cuyo su nombre indica, pasaban revista a los principales acontecimientos para que el público estuviera informado, equivalente a un periódico. Este género fue del gusto de la población capitalina, ya que de esta manera se enteraba de las principales noticias y a la vez se divertía.

Posterior al teatro político, surgió el teatro de variedades, que fue un género en el que se presentaba una diversidad de números artísticos, como bailes, números musicales, ilusionismo, fenómenos, malabares, entre otros, ya sin un trasfondo político.

Ahora, las carpas fueron pequeños teatros instalados provisionalmente en las plazas públicas, que iban de una manera trashumante por toda la ciudad. En ellas se representaban una diversidad de espectáculos de género chico, especialmente teatro de revista, pero también hubo exhibiciones de cinematógrafo, números circenses y musicales, entre otros.

La tanda fue una forma de vender el teatro por horas, esencialmente de género chico, lo cual permitió la accesibilidad de las clases populares a los teatros, ya que los boletos tenían un costo menor a las obras de género grande, es decir la ópera y las obras mayores de un acto. La tanda es un elemento imprescindible para definir mi concepción de teatro popular, ya que a través de ella el teatro fue accesible a las clases populares, ya sea en teatros establecidos o en carpas. 


\section{LAS DIVERSIONES PÚBLICAS EN LA CIUDAD DE MÉXICO}

Es necesario contextualizar el espacio donde se desarrolla el objeto a investigar, por lo que en este capítulo se ofrece una visión de la ciudad de México en los sentidos urbano, social, cultural y político, sabiendo que inicia el siglo xx con el seguimiento de la política porfirista de "orden y progreso" que se ve reflejada en importantes transformaciones urbanas, y por ende en el particular uso de la ciudad por parte de la población, mucha de ella migrante que llega a la metrópoli buscando mejores opciones para ganarse la vida.

El crecimiento urbano de la ciudad es un factor que detona el surgimiento de nuevas apropiaciones del espacio por todos los sectores de la sociedad; la ampliación de avenidas, la construcción de nuevos edificios y zonas habitacionales, la concentración de servicios o la habilitación de espacios públicos, el implemento de nuevos medios de transporte, son algunos elementos que influyen en la instalación de los lugares que ofrecen esparcimiento a la población.

Asimismo es importante tomar en cuenta la vida cotidiana de la población capitalina, tanto de la clase social alta como del pueblo, ya que a partir de ello podríamos entender mejor su accesibilidad y preferencia de determinadas diversiones.

En otro apartado se ofrece un panorama general sobre la variedad de diversiones públicas que se pueden disfrutar en la ciudad y cómo fue cambiando la manera de entretenerse, desde los teatros de títeres hasta la lucha libre, pasando por los principales deportes que gustaba la población capitalina. Se tomará en cuenta tanto las diversiones de los grupos de élite, como las de las clases populares; la influencia de otros países, como el desarrollo de géneros teatrales y eventos deportivos, así como de los avances en la tecnología utilizados para el esparcimiento social, como fue el caso del cinematógrafo y otros aparatos de proyección visual. Lo anterior va ligado con la función que tuvieron las diversiones públicas para la reproducción social y el cambio en la vida cotidiana de los capitalinos.

También se hablará de los teatros como entes que formaron parte de la estructura urbana, tomando en cuenta los parámetros de modernización o 
marginación según sea el caso de los teatros de élite o las carpas, para empezar a ubicar gradualmente a nuestro objeto de estudio en su contexto territorial. Asimismo se pretende ofrecer un panorama de su ubicación y uso social, acorde a las costumbres porfirianas, el impacto que tuvo la lucha armada en las diversiones públicas y la alteración de las mismas por parte de los parámetros urbanos acaecidos al finalizar la primera mitad del siglo XX.

\section{CIUDAD Y SOCIEDAD}

La ciudad de México inició el siglo xx con amplias calles pavimentadas, áreas verdes, zonas residenciales, infraestructura eléctrica, nuevos medios de transporte y grandes redes subterráneas de desagüe, obras que reflejaron la implementación tecnológica para la satisfacción de las necesidades urbanas de la sociedad del momento. La ciudad fue creciendo conjuntamente con las innovaciones tecnológicas, modelos arquitectónicos vanguardistas y obras de ingeniería acordes a las metrópolis más avanzadas del mundo.

Como expresión del orden porfiriano, las calles no fueron secundarias en los planes de urbanistas y gobernantes. Su carácter moderno se ponderaba por su anchura, por las fachadas y edificios que las limitaban, por el estado de las banquetas, por los accesos para los automotores, por los medios de transporte que circulaban por ellas, así como por el comportamiento de sus habitantes en ese espacio público por excelencia. Debían ser fiel reproducción de las principales calles de las grandes ciudades europeas y estadounidenses. $^{26}$

Los faroles y el "sereno" empezaron a ser desplazados por el alumbrado eléctrico, que le daban un toque más moderno a las calles y según el pensamiento de la época, brindaba seguridad y era resguardo contra la inmoralidad. ${ }^{27}$

Por mucho tiempo esta ciudad fue predominantemente lacustre, sin embargo la urbanización que acompaña a la modernidad fue ganando terreno al agua, los nuevos medios de transporte eléctrico desplazaron a las canoas "[...]

\footnotetext{
${ }^{26}$ Mario Barbosa Cruz, El trabajo en las calles. Subsistencia y negociación política en la ciudad de México a comienzos del siglo XX, El Colegio de México-UAM-C, México, 2008, pág. 56.

${ }^{27}$ Engracia Loyo Bravo, "El México revolucionario (1910-1940)", en Pablo Escalante Gonzalbo et al., Historia mínima de la vida cotidiana en México, México, El Colegio de México, 2010, pág. 181.
} 
este valle que aún no perdía ese hábitat lacustre que lo caracterizó hasta comenzar el siglo $\mathrm{xx}$, antes de que los antiguos canales se transformaran en amplias avenidas en donde no queda rastro de ellos más que el nombre del viejo cauce de agua". ${ }^{28}$ El canal de la Viga, que fue tan importante como principal medio de transporte de productos agrícolas procedentes de Iztacalco, Iztapalapa, Tláhuac y Xochimilco aún siguió siendo utilizado hasta la década de 1940, sin embargo el centro histórico ya quedaba sin huella lacustre alguna. La ciudad podía fijar sus límites entonces a los extremos hasta Tlatelolco, San Lázaro y la Ciudadela.

La urbanización descomunal de la ciudad alcanzó parámetros no antes logrados durante el siglo XIX. Esto se ve reflejado con la formación de las primeras colonias porfirianas de la capital, como la Juárez, la Roma, la Guerrero, la Santa María Ribera y la de los Arquitectos. El espacio cada vez se vuelve más urbano, sin embargo los pueblos siguen llevando una vida rural en los alrededores.

Entre 1900 y 1930 aumentaron las autorizaciones para la construcción de zonas habitacionales; además se expidió un reglamento para el establecimiento de nuevas colonias. ${ }^{29}$ El diseño urbano de la ciudad se trazaba acorde a la idea de que las clases no debían mezclarse, se buscaba "una división racional entre las áreas centrales, seguras y bellas de la ciudad moderna y las zonas marginales, peligrosas e insalubres". ${ }^{30}$ Esto se debía en gran parte a los vínculos cercanos que tuvieron los inversionistas privados con los funcionarios de la ciudad. ${ }^{31}$ De manera tal que en la misma urbe coexistían parámetros establecidos para una ciudad moderna junto con prácticas tradicionales y rústicas.

La ciudad crecía a ritmos acelerados, "gran parte de las nuevas áreas urbanizadas correspondieron a colonias para las élites y los sectores medios; allí se construyeron grandes casas en espacios con baja densidad de población" ${ }^{32} \mathrm{El}$

\footnotetext{
${ }^{28}$ Mario Barbosa Cruz, "La ciudad de México durante la Revolución. Miradas desde la historiografía reciente", en Gustavo Leyva et al., (coordinadores), Independencia y Revolución: pasado, presente y futuro, UAM-FCE, México, 2010, pág. 307.

${ }^{29}$ Mario Barbosa Cruz, El trabajo en las calles, op. cit., pág. 67.

30 Pablo Piccato, Ciudad de sospechosos: crimen en la ciudad de México, 1900-1931, CIESAS-FONCA, México, 2010, pág. 39.

31 Ibidem, pág. 46.

${ }^{32}$ Mario Barbosa Cruz, El trabajo en las calles, op. cit., pág. 42.
} 
aumento de la ciudad no consideró suficiente espacio para la mayoría de las clases bajas, incluso esta población ocupó las colonias cercanas al centro, mientras que las élites se trasladaron hacia el poniente de la ciudad. ${ }^{33}$ Por lo tanto existió un comportamiento de movilidad poblacional en el territorio siguiendo el patrón de evitar la mezcla de las clases sociales. En las nuevas colonias de élite se concentraba la mayoría de los servicios urbanos, en cambio el área poblada por las clases bajas carecía de los beneficios implementados hasta la fecha, numerosa población vivía hacinada en hogares precarios.

Mientras las clases altas se establecían en las nuevas colonias de la ciudad, muchas de las casonas que años atrás funcionaron como palacios 0 claustros de conventos fueron abandonados gradualmente por las élites desde el siglo XIX, y se convirtieron en vecindades con altos índices de hacinamiento. En aquellas vecindades se manifestaba obligadamente una convivencia comunitaria, los lavaderos se utilizaban entre todos los vecinos, y los patios eran usados para que los niños jugaran y se realizaran las fiestas familiares. Esto evidencia que la modernidad tuvo sus límites al no poder hacer de lo comunitario algo privado.

Paralelamente con las tendencias positivistas, existía también el propósito de erradicar las prácticas inmorales de las clases populares, que eran prejuiciadas por las élites, ya que las consideraban un impedimento para la modernidad.

La nota general a finales del Porfiriato fue, sin duda, la de identificar al llamado "pueblo bajo" con los estratos más peligrosos y menos educados de la sociedad mexicana, es decir, con aquellos que podían tener todo menos una cultura. Los sectores dirigentes y estudiosos de la sociedad mexicana le adjudicaban a ese pueblo bajo un tono melancólico, sufrido, resignado, desconfiado, apático, cuando no violento y criminal. ${ }^{34}$

Por otra parte, mientras la ciudad se desarrollaba, seguían subsistiendo prácticas rústicas. A principios del siglo XX, en el jardín de Tumbaburros, ${ }^{35}$ los arrieros

\footnotetext{
33 Ibidem, pág. 43.

${ }^{34}$ Ricardo Pérez Montfort, "El pueblo y la cultura. Del Porfiriato a la Revolución", en Raúl Béjar y Héctor González (coordinadores), La identidad nacional mexicana como problema político y cultural. Nuevas miradas, UnAM, México, 2005, pág. 68.

${ }^{35}$ El Jardín de Tumbaburros se localizaba frente a la fuente del Salto del Agua, ahí se detenían los arrieros procedentes de pueblos aledaños y de provincia, y sus burros se echaban a descansar en ese lugar, de ahí su nombre.
} 
descargaban a las bestias que venían del Estado de México, Tlaxcala, Puebla y Oaxaca, así como de Xochimilco y Tláhuac. ${ }^{36}$ La ciudad de México era el punto fundamental de mucha gente para el intercambio de mercancías y el uso del equipamiento e infraestructura que no había en otros lugares. En 1900 dos de cada tres personas eran originarios de otros estados. ${ }^{37} \mathrm{Al}$ comenzar del siglo $\mathrm{xx}$ había unos 350000 habitantes en la ciudad de México y gran parte de la población no tenía actividad específica según los parámetros estadísticos ${ }^{38}$ lo que significa que muchos habitantes basaban su sustento en actividades informales. A pesar de que durante el Porfiriato las actividades industriales alcanzaron gran auge, en 1910 la ciudad no podía considerarse aun predominantemente industrial, ya que mucha población se dedicaba a otras diversas actividades, entre ellas el comercio y las prácticas agrícolas.

Los parámetros de planificación urbana modificaron la estructura establecida en la ciudad desde años atrás, una multitud de edificios fueron demolidos para ampliar las calles del centro de la ciudad. El mismo Teatro Nacional fue demolido para ampliar la avenida 5 de mayo, sin embargo muchos otros grandes recintos se mantenían en pie, dando a la ciudad una vida teatral intensa, y más aún a partir de 1910 debido a las fiestas del centenario de la independencia nacional, estaba en construcción el nuevo Teatro Nacional, que posteriormente se convirtió en el Palacio de Bellas Artes; mientras que en la periferia y espacios populares seguían estableciéndose teatros de barrio, hasta en algunos casos se les tenía prohibido instalarse en las plazuelas públicas debido a la remodelación de estos espacios.

Dentro de los preparativos de los festejos del centenario se realizaron, entre otras acciones, el "remozamiento de jardines y paseos, construcción de edificios para las exposiciones de 1910 y nuevas sedes para las instituciones públicas. Septiembre de 1910 fue un mes plagado de exhibiciones públicas, actos cívicos e inauguraciones de museos y edificaciones para centros de educación y de

\footnotetext{
${ }^{36}$ Pedro Granados, op. cit., pág. 22.

37 Elisa Speckman Guerra, “De barrios y arrabales: entorno, cultura material y quehacer ciudadano (ciudad de México, 1890-1910)", en Aurelio de los Reyes (coordinador), Historia de la vida cotidiana en México: tomo v. Siglo XX, campo y ciudad, Volumen 1, El Colegio de México-FCE, México, 2006, pág. 29.

${ }^{38}$ Mario Barbosa Cruz, El trabajo en las calles, op. cit., pág. 32.
} 
asistencia pública". ${ }^{39}$ Esto de alguna manera pretende demostrar la consolidación de la modernidad que había alcanzado hasta el momento la ciudad de México. Sin embargo aquel punto logrado por el Porfiriato llegó a su tope al estallar el movimiento armado.

\section{La ciudad durante la lucha armada}

Durante la década revolucionaria en la ciudad se desarrollaron diversos acontecimientos que involucraron los cambios de gobierno, la caída de Díaz, la llegada del Maderismo, los hechos de la Decena Trágica, el triunfo de las fuerzas revolucionarias contra Victoriano Huerta, el paso y confrontaciones de las fuerzas revolucionarias y federales a partir de 1914. Junto a estos hechos se generó una desestabilidad del comercio y abasto interno, la muerte de miles de personas, la emigración de muchas otras que huían de la violencia y el hambre acaecida en la capital. "La ciudad no sólo vivió las consecuencias de una confrontación en zonas del territorio mexicano, de la disminución de la producción agrícola y la interrupción de los flujos de la red de ferrocarriles. Sus habitantes también sufrieron cambios en sus formas de vida y aprendieron a vivir los rigores de una revolución" ${ }^{40}$ Si bien la ciudad de México no fue el escenario principal de las luchas armadas, sí se le consideró como un espacio simbólico de administración, por lo que ocuparla fue una forma de manifestar el poder de quien lo hacía.

Por largos meses la ciudad de México se desquició: "amanecía villista, almorzaba constitucionalista, merendaba zapatista". Salían y entraban tropas, la gente se refugiaba donde podía, en los almacenes, en las iglesias [...] La carencia de agua y, por tanto, la falta de higiene propiciaron enfermedades epidémicas. La huelga de tranviarios acabó de paralizar el tránsito de la ciudad, inmovilizada ya por la ausencia de electricidad y alumbrado. $^{41}$

39 Mario Barbosa Cruz, "Límites de la modernización de la capital mexicana durante la década revolucionaria", en Mario Barbosa Cruz y Salomón González (coordinadores), Problemas de la urbanización en el Valle de México, 1810-1910. Un homenaje visual en la celebración de los centenarios, UAM, México, 2009, pág. 265.

${ }^{40}$ Ibidem, pág. 283.

${ }^{41}$ Engracia Loyo Bravo, op. cit., pág. 190. 
Al transcurrir la lucha armada hubo momentos dramáticos para los habitantes de la ciudad de México como lo menciona un documento constitucionalista que señalaba que "201 personas perecieron de inanición en agosto de 1915. A fines de ese mes, un periódico se dio en desmentir un informe de la Cruz Roja norteamericana, que aseguraba que entre 30 y 40 personas morían diariamente de hambre en la ciudad. De resultar cierta la estimación de la Cruz Roja, el total de muertes por hambre en agosto no estaría alejadas de las mil". ${ }^{42}$ El panorama era difícil en muchos ámbitos de la vida diaria de los habitantes de la ciudad, aunque la situación más crítica tenía que ver con el hambre.

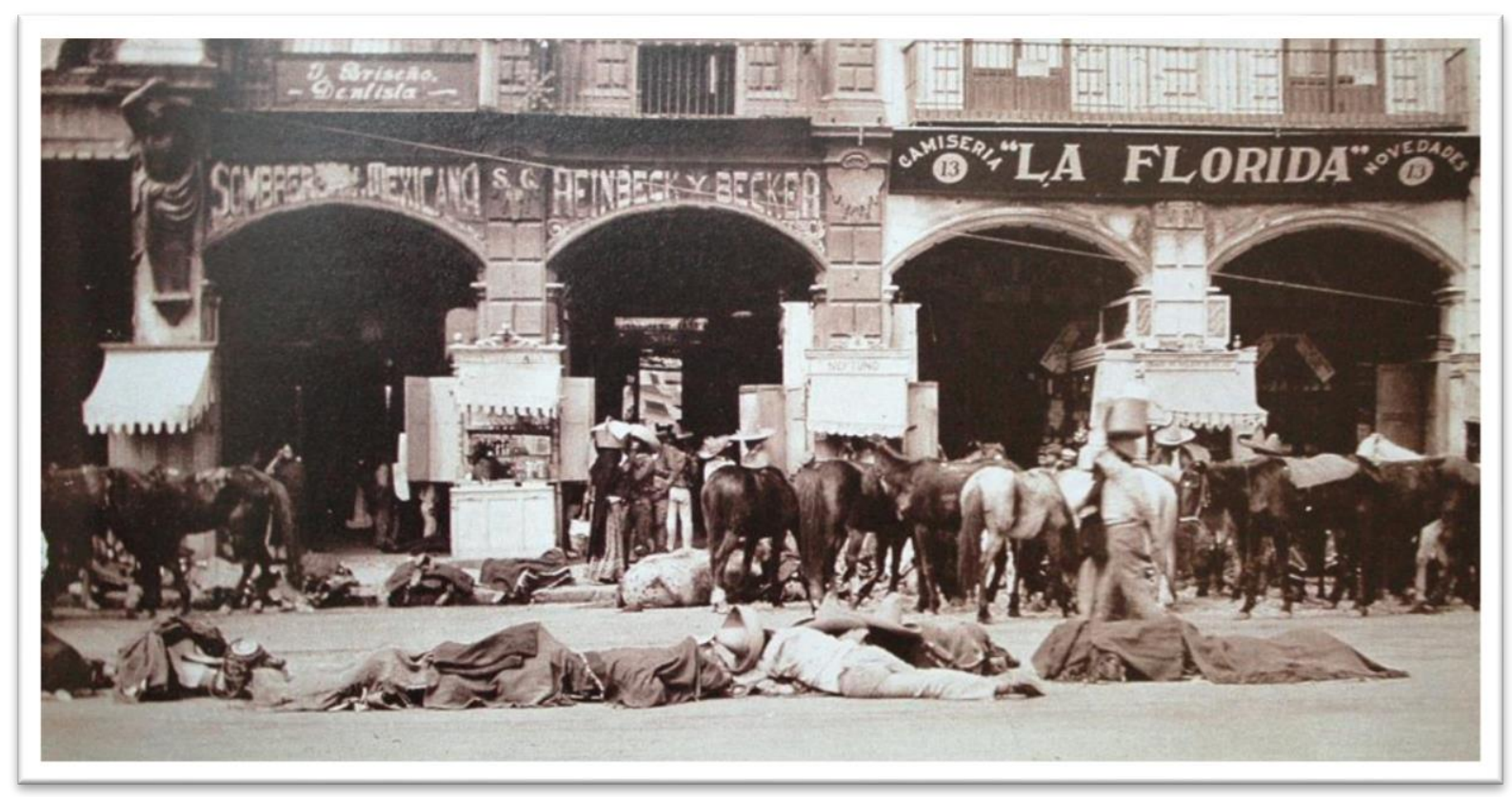

La población de la ciudad de México padeció gravemente durante el movimiento armado, una de las mayores desgracias fue la decena trágica, que dio como resultado numerosas muertes civiles.

Fuente: Fototeca INAH.

Otro de los problemas para los habitantes de la ciudad fue la insalubridad de los alimentos. "Incluso se multiplicaron las denuncias por venta y consumo de sobras de comida en los mercados, conocidas con el nombre de escamocha". ${ }^{43}$

\footnotetext{
${ }^{42}$ Ariel Rodríguez Kuri, “Desabasto, hambre y respuesta política, 1915”, en Illades, Carlos y Rodríguez Kuri, Ariel (compiladores), Instituciones y ciudad. Ocho estudios históricos sobre la ciudad de México, Ediciones Uníos, México, 2000, pág. 133.

43 Mario Barboza Cruz, "Límites de la modernización de la capital mexicana durante la década revolucionaria", op. cit., pág. 284.
} 
Esto ocasionó el surgimiento de epidemias como el tifo y la influenza, principalmente entre 1915 y 1918.

\section{La ciudad posterior a la Revolución}

La imagen de la ciudad de México, después de la lucha armada, fue objeto de estudio para los arquitectos y planificadores. Se pretendía concebir a la ciudad de una manera diferente a como fue ideada durante el gobierno de Porfirio Díaz. En cierta medida se trató que la imagen urbana ya no fuera el reflejo de la "tiranía" porfiriana con sus grandes edificios estilo francés, ahora se procuró encontrar un discurso urbano-arquitectónico acorde a la identidad nacional.

Uno de los principales promotores en los años veinte fue José Vasconcelos. Tomar partido por una arquitectura no afrancesada, proponer el churrigueresco como el estilo nacional, y volver los ojos a las necesidades de urbanización popular fueron las opciones elegidas por los arquitectos en el favorable contexto de los primeros gobiernos posrevolucionarios. ${ }^{44}$

Debido al constante aumento de la población y las facilidades de inversión en el fraccionamiento de tierras, se mantuvo un crecimiento acelerado de la mancha urbana. "Incluso durante la década revolucionaria continuó el fraccionamiento y la venta de terrenos a precios módicos para enfrentar los tiempos de crisis". ${ }^{45}$ Mientras, por una parte, la ciudad seguía creciendo acorde a los parámetros porfirianos, incursionaron otras ideas que trataban de romper el paradigma antes establecido. Pablo Piccato argumenta que después de la lucha armada, el desarrollo urbano siguió manteniendo los parámetros establecidos durante el régimen porfirista.

Después de 1920, la capital volvió lentamente a mejorar su imagen [...] El área de la ciudad se triplicó en diez años. Los autos llegaron a dominar el tránsito y para 1928 se prohibieron los vehículos tirados por animales, conforme los funcionarios retomaron su ataque contra las prácticas de los pobres urbanos. ${ }^{46}$

\footnotetext{
${ }^{44}$ Mario Barbosa Cruz, El trabajo en las calles, op. cit., pág. 48.

45 Ibidem, pág. 34.

${ }^{46}$ Pablo Piccato, Ciudad de sospechosos, op. cit., pág. 57.
} 
Por otra parte, en los primeros gobiernos posrevolucionarios se abandonó la prioridad porfiriana del "monumentalismo edilicio para abordar la problemática de la vivienda barata". ${ }^{47}$ Estas medidas fueron orientadas a enfrentar el problema de la densificación y mejorar el nivel de vida de la población, retomadas por los primeros gobiernos posrevolucionarios. ${ }^{48}$ Para entonces la ciudad ya había crecido de manera considerable, y con ella los problemas urbanos. El gobierno del Distrito Federal se quejaba de la miopía de las administraciones anteriores por su falta de una visión clara de los problemas planteados por la expansión urbana. ${ }^{49}$

Incluso en 1927 se creó la Asociación Nacional para la Planificación de la República Mexicana, debido a que "Los primeros intentos de planeación entre 1900 y 1930 consideraron sólo de manera tangencial a los sectores en donde residían las mayorías pobres de la ciudad" ${ }^{50}$ A partir de entonces el discurso del crecimiento urbano tomó nuevos parámetros de acuerdo a las necesidades reales de la población capitalina tomando en cuenta las tendencias de su crecimiento.

Para 1928 hubo una reestructuración del Distrito Federal, se propuso eliminar el municipio en esta entidad, dejando tan solo las bases que deberían regir para la organización de los territorios. ${ }^{51}$ En diciembre de ese año el presidente Emilio Portes Gil expidió la primera Ley Orgánica del Distrito y de los Territorios Federales, en donde se definió que el órgano a través del cual el presidente ejercía el gobierno del Distrito Federal sería el Departamento del Distrito Federal. ${ }^{52}$ Un año después se suprimió el régimen municipal, con lo que las trece municipalidades existentes en su territorio desaparecieron y más tarde sería promulgada una ley que dividió la entidad en 16 delegaciones políticas.

Mientras tanto, los automóviles dejaron de ser vehículos de lujo para convertirse en medio de transporte cotidiano de la población, ya sea como

\footnotetext{
${ }^{47}$ Rafael López Rangel, La planificación y la ciudad de México 1900-1940, UAM-A, México, 1993, pág. 58.

${ }^{48}$ Mario Barbosa Cruz, El trabajo en las calles, op. cit., pág. 47.

49 Érica Berra Stoppa, La expansión de la ciudad de México y los conflictos urbanos, 1900-1930, El Colegio de México, México, 1982, pág. 321.

${ }_{50}^{50}$ Mario Barbosa Cruz, El trabajo en las calles, op. cit., pág. 49.

${ }^{51}$ Salomón Díaz Alfaro, "El Distrito Federal mexicano. Breve historia constitucional”, en María del Carmen Álvarez Castro (coordinadora), Estudios Jurídicos en torno a la Constitución mexicana de 1917 en su septuagésimo quinto aniversario, IIJ-UNAM, México, pág. 213.

${ }^{52}$ Ibidem, 215.
} 
propiedad particular, de alquiler o transporte público. "Si bien hacia 1918 los carros de tracción animal eran aún más numerosos que los automóviles, a partir de 1927 se prohibió el tránsito de los primeros por las calles asfaltadas de la ciudad con el fin de facilitar el tránsito cada vez más importante de los segundos [...] En 1929 recorrían las calles del Distrito Federal 17435 automóviles, entre vehículos oficiales, particulares y de alquiler". ${ }^{53}$ Lo cual demuestra una vida citadina cada vez más dinámica.

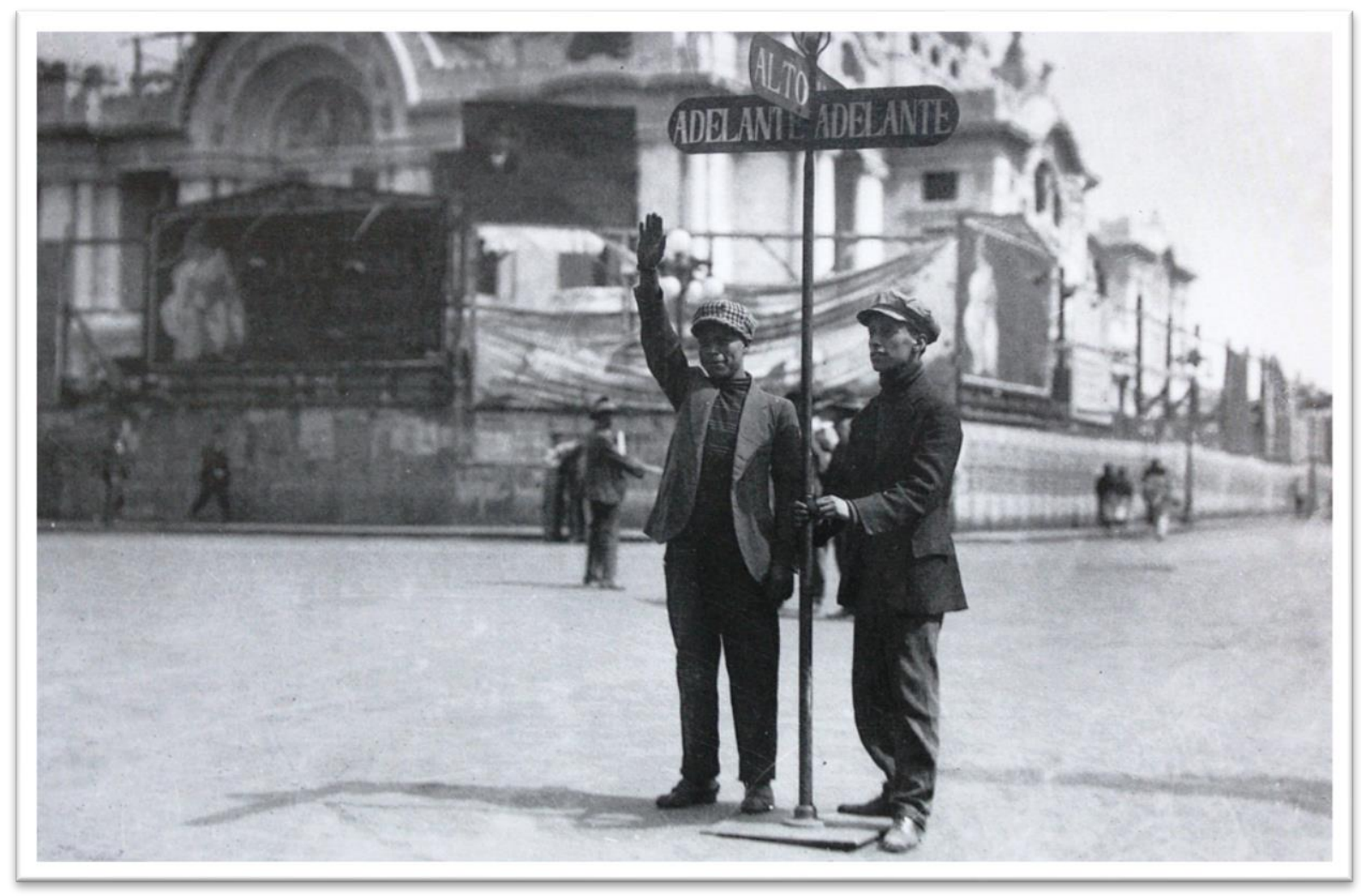

Semáforos humanos para agilizar el flujo de vehículos automotores, que en la década de 1920 se incrementa de manera importante.

Fuente: Fototeca INAH.

Debido a la demanda de transporte, florecieron diversas compañías de autobuses urbanos, que con prontitud contaron con un gran número de líneas distribuidas por diferentes puntos de la urbe. ${ }^{54}$

\footnotetext{
53 Érica Berra Stoppa, op. cit., pág. 346.

${ }^{54}$ Ibidem, pág. 322.
} 
La ciudad se tornaba cada vez más expresiva y ruidosa. La explosión de los escapes de las camionetas y el chirrido de los tranvías se hacían paulatinamente más insoportables; el estruendo de las bocinas de los autos que, con ímpetu, se abrían paso en medio del tráfico, rompía los tímpanos de los transeúntes, y los alaridos de los cobradores de los autobuses que, sin descanso, anunciaban en cada esquina el trayecto de los puntos del recorrido. ${ }^{55}$

En la década de 1930 se realizaron diversos cambios en la fisionomía de la ciudad. En 1935, durante el gobierno de Lázaro Cárdenas, San Juan de Letrán es ampliada, la primera gran avenida que iniciaría la transfiguración de la capital. Con su ampliación vinieron los derrumbes de muchas casonas y vecindades, en muchos de los predios baldíos se instalaron carpas; Pedro Granados hace mención de varias de ellas que se instalaron en San Juan de Letrán: Teatro Colonial, El Salón Rojo, La Ofelia, El Salón París, La Principal, La Procapio, entre otras. ${ }^{56}$ Asimismo se tiraron diversos edificios para ampliar calles, según lo exigían las necesidades de flujo automotriz. En 1935 se abre la avenida 20 de noviembre para ofrecer un mejor acceso al primer cuadro de la ciudad. Y así como esta avenida, se ampliaron muchas otras que llevaron a la destrucción de viejas edificaciones. A partir de entonces las nuevas construcciones tomaron otros estilos arquitectónicos, como el neocolonial, art decó, art nouveau, sobre todo en las colonias como Portales, Álamos, Doctores, Obrera, al sur poniente del centro histórico.

En la década de 1940 hubo más derrumbes bajo la jefatura de Javier Rojo Gómez, como la ampliación de las calles de Cuauhtemotzin que se borró del mapa al popular barrio Latino. "Años más tarde, Ernesto P. Uruchurtu tuvo a bien dar jaque mate a todo el barrio. Se acabaron las carpas, los puestos y la vendimia, desaparecieron tugurios y hoteluchos, [...] los restaurantes y cafés cerraron sus puertas". ${ }^{57}$ Para entonces las autoridades se empeñaron en establecer mayor orden en la ciudad así como en la sociedad. Asimismo, la ciudad se industrializa de manera acelerada, el espacio priorizó a la instalación de industrias y la población incursionaba en la mano de obra, lo que trae como consecuencia el

\footnotetext{
${ }^{55}$ Ibidem, pág. 327.

${ }_{56}^{56}$ Pedro Granados, op. cit., pág. 38.

${ }^{57}$ Ibidem, pág. 48.
} 
reacomodo urbano y el crecimiento exponencial de la población. Para la década de 1940 ya había más de un millón de habitantes en la ciudad de México. ${ }^{58}$

\section{Alternativas DE ESPARCIMIENTO SOCIAL}

¿Qué función tienen las diversiones en la vida cotidiana de la sociedad?, es difícil imaginar una vida laboral continua sin tener descanso y recuperar energía para seguir trabajando, lo cual se convierte en un círculo vicioso entre trabajo y reposo. "El hombre utiliza una parte de su tiempo vital para el descanso, entendido como el no-trabajo,[...] por cada jornada de labor hay un tiempo más o menos semejante de no-trabajo. ${ }^{59} \mathrm{Si}$ sumamos a esto el hecho de que el esparcimiento generalmente es una actividad que se realiza en compañía, podemos decir que las diversiones son parte dicotómica de las relaciones laborales, y en un entorno público cada persona, al estar libre de trabajo, se aglutina con otros individuos con igual libertad para recrearse en colectivo, compartir su tiempo libre y así continuar reproduciendo su respectiva función laboral dentro de la sociedad.

A principios del siglo XX "La gente deseosa de olvidar sus problemas atiborraba las carpas y jacalones; reía y festejaba a los actores improvisados y aprovechaba la ausencia de vigilancia para explayarse y desahogarse a costa de un mal cantante, una mala bailarina o un pésimo actor". ${ }^{60}$ La risa es la característica distintiva del hombre. En el teatro como en la vida nos sirve de alivio. ${ }^{61}$ La población capitalina buscaba maneras para relajarse después de la jornada laboral, y las diversiones públicas siempre fueron sus preferidas, muchas de ellas se disfrutaban de manera colectiva.

Para entender cómo se divertían los capitalinos durante la primera mitad del siglo XX es necesario analizar sus relaciones sociales ya que no todos los habitantes de la ciudad se divertían de la misma manera. Incluso durante el siglo

\footnotetext{
${ }^{58}$ Gustavo Garza, La urbanización de México en el siglo Xx, México, El Colegio de México, 2005.

59 Juan Ricardo Jiménez Gómez, "Diversiones, fiestas y espectáculos en Querétaro", en Anne Staples (coordinadora), Historia de la vida cotidiana en México: tomo IV: Bienes y vivencias. El siglo XIX, El Colegio de México-FCE, México, 2005, pág. 333.

${ }^{60}$ Aurelio de los Reyes, Cine y sociedad en México, 1896-1930. Volumen I, Vivir de sueños, IEE-UNAM, México, pág. 32.

61 John Dowling, "Teatro cómico y lo cómico en el teatro español de la posguerra", en Hispania, vol. 60, no. 4, diciembre, 1977, pág. 905.
} 
XIX sólo ciertas diversiones contaron con la aprobación de las autoridades, ya que se consideraba que "después del trabajo, las horas de asueto debían dedicarse a promover la educación, la cultura y el bienestar de los ciudadanos". ${ }^{62}$ La mirada vigilante de las autoridades suponía que el ocio honesto estaba organizado, mientras que el deshonesto, carente de normas y reglas, debía prohibirse. ${ }^{63}$ Esta postura positivista del uso del tiempo libre se conservó durante el Porfiriato como forma de mantener controlada a la población.

Las actividades recreativas también juegan un papel importante para posicionarse con cierto status en un sentido exhibicionista, por lo menos entre los grupos de élite y los gobernantes, ya que se hacían mostrar en eventos sociales. "Los presidentes solían asistir a conciertos o a representaciones operísticas quizá para disfrutar pero más para exhibirse y hacer simpatías entre sus gobernados", ${ }^{64}$ sobre todo se les solía ver en funciones de beneficio para adquirir simpatía entre los de su círculo y la población. El espacio y tipo de diversión de los capitalinos tenía un significado determinante en los actos de la vida cotidiana y en las manifestaciones culturales de la ciudad.

El crecimiento de la mancha urbana fue acompañado de la segregación social, ya que se dispusieron espacios separados entre la élite y los grupos populares. Las clases altas desplazaron sus actividades de entretenimiento a las nuevas colonias del poniente de la ciudad. Desde finales del siglo XIX "la segregación social acompañó el proceso de crecimiento urbano y dispuso espacios separados para los grupos de élites y los grupos populares", 65 parámetro que continuó en el siglo Xx. Para la clase alta, los paseos a pie en la Alameda se abandonaron poco a poco dando paso a las reuniones de clubes de bicicletas y patinaje que organizaban recorridos hacia el castillo de Chapultepec. ${ }^{66}$ Las

\footnotetext{
62 María Dolores Lorenzo Río, "Entre el vicio y el beneficio. Segregación social y espacios de entretenimiento en la Ciudad de México, 1810-1910", en Mario Barbosa Cruz y Salomón González (coordinadores), Problemas de la urbanización en el Valle de México, 1810-1910. Un homenaje visual en la celebración de los centenarios, UAM, México, 2009, pág. 227.

${ }^{63}$ Ibidem, pág. 232.

${ }^{64}$ Aurelio de los Reyes, Cine y sociedad en México, 1896-1930. Vol. II. Bajo el cielo de México (1920-1924), IIEUNAM, México, 1993, pág. 38.

${ }^{65}$ María Dolores Lorenzo Río, op. cit., pág. 255.

${ }^{66}$ Ibidem, pág. 248.
} 
maneras de disfrutar el tiempo libre de cada grupo social eran totalmente diferentes.

El entretenimiento de cada grupo social estaba relacionado con su accesibilidad económica, cultural o territorial. La oferta de diversiones públicas fue muy basta y estaba relacionada con la influencia de otros países y los nuevos inventos como el fonógrafo, el vitascopio, el cinematógrafo, entre otros. Las familias podían salir a divertirse en las calles y así lograr un sano esparcimiento además de darle vida a la ciudad, cuestión que va desapareciendo con la llegada de la radio y la televisión, que fomentaron a que las personas no tengan necesariamente que salir de su casa para divertirse.

Durante el Porfiriato las diversiones públicas no tenían los mismos objetivos para las diferentes clases sociales.

Lo que se entendía específicamente como "diversiones públicas" eran más bien aquellos acontecimientos que podían romper con la tediosa cotidianidad y proporcionaban a los ciudadanos clasemedieros y bien acomodados algún momento de goce estético, esparcimiento o simplemente los alejaba temporalmente de la rutina. Rara vez la connotación de "diversión pública" incorporaba a marginados, pelados, a la plebe, al "populacho", que bien a bien no era considerado capaz de estar dentro de los estrechos márgenes que entonces limitaban la idea de "pueblo mexicano" ${ }^{67}$

Por otra parte, también hubo preocupaciones por ayudar a los espectáculos populares con el objetivo de alejar del vicio a las clases sociales bajas, como lo solicita un inspector al Ayuntamiento en 1922:

Como es de muy tener en cuenta que el público que asiste a estos espectáculos es en general de la clase baja del pueblo y obreros y trabajadores un poco mejores que la más baja, y pagan por permanecer dos o tres horas en dichas carpas cuotas sumamente bajas, hay que buscar un medio de que no desaparezcan esta clase de espectáculos, pues es siempre preferible la carpa a la pulquería y la taberna, donde con absoluta seguridad pagan más y se embrutecen más, puesto que en la carpa si no se ilustra, cuando menos se divierten sanamente y menos inmoralmente que en los centros de vicio. Además, también

${ }^{67}$ Ricardo Pérez Montfort, “Circo, teatro y variedades”, op. cit., pág. 88. 
debe tenerse en cuenta el número de personas más o menos grande, unos veinte 0 veinticinco por carpa, que con el carácter de artistas y empleados viven de ellos. ${ }^{68}$

Este inspector solicita que se apoye a las carpas para que mejoren sus condiciones, y así las clases populares cuenten con espacios más dignos para divertirse y prefieran asistir a los espectáculos a estar en las cantinas.

Hay que tomar en cuenta a las diversiones públicas como actividades en constante lucha contra los vicios de la sociedad ya que, según Aurelio de los Reyes, el grado de alcoholismo era muy alto, sobre todo en los estratos bajos, y muchos obreros gastaban sus salarios en embriagarse, por lo que "Los diarios llamaban una y otra vez la atención sobre el problema, [...] se sugería que el Ayuntamiento fomentara las diversiones públicas de bajo precio, o que subvencionase compañías de teatro, para que los espectáculos tuvieran cierta calidad moral", ${ }^{69}$ esto se procuraba para que la sociedad tuviera una opción para recrearse dignamente y se alejara del alcoholismo que representaba un impedimento para seguir los patrones de modernidad orientados desde el gobierno.

Durante la primera década del siglo XX se manifestaron múltiples opciones de entretenimiento para todos los sectores de la sociedad, muchos de ellos se fueron adaptando acorde a las transformaciones de la vida cotidiana de la población, a las influencias de otros países, así como a los avances tecnológicos, como es el caso del cinematógrafo, la radio y otras maneras de ocupar el tiempo libre. Muchas de estas actividades no hacían competencia para atraer a más espectadores, sino que todas formaban un complejo de opciones según las exigencias de la sociedad.

Para 1911, según el Ayuntamiento "toda diversión, sintéticamente considerada, tiene por objeto fundamental, valiéndose del Arte, solazar, causar placer, proporcionar descanso, o cuando menos servir de correcto pasatiempo [...] si la Estética es el fin principal, deben como fines accesorios, hasta donde sea

${ }^{68}$ AHDF, Fondo: Ayuntamiento; Sección: Diversiones públicas; vol. 812. exp. 1708.
${ }^{69}$ Aurelio de los Reyes, Los orígenes del cine en México (1896-1900), FCE, México, 1983, pág. 72. 
posible, ir con ella la Moral y la Lógica"70, y para entonces el Ayuntamiento divide a las diversiones de la capital en cuatro grupos: teatros, coscos, cinematógrafos y las demás diversiones (hipódromos, circos, frontón, caballitos, entre otros).

Sin embargo, la oferta de diversiones públicas en la ciudad de México contaba con mayor variedad, pero no todas estaban al alcance de la mayor parte de la población. "Para los empresarios, los banqueros, los comerciantes, los profesionistas y los políticos notables, había salones y casinos que restringían la entrada al público en general". ${ }^{71}$ Montar en bicicleta y andar en el Paseo de la Reforma fue una actividad para el mexicano "moderno", era una prueba de su riqueza, posición y, sobre todo, de su carácter progresista. ${ }^{72}$ El patinaje fue otra actividad preferida para la élite. "La moda pronto se dejó ver en las calles y resultó tan riesgosa que en 1907 el jefe de policía prohibió patinar en calles y aceras, especialmente a partir del atardecer". ${ }^{73}$

A principios del siglo XX, en las principales plazas de la ciudad se ubicaba la mayoría de las diversiones públicas accesibles a las clases populares, "la vida de los barrios estaba articulada de acuerdo con patrones demográficos que constituían "públicos" de los espectáculos de feria, del género chico, la zarzuela, las variedades y, en su momento, del cinematógrafo", ${ }^{74}$ este tipo de público estaba constituido en su mayoría por obreros y artesanos.

Para ofrecer cualquier tipo de espectáculo se necesitaba el consentimiento del Ayuntamiento, como lo demuestra el caso del señor José Balderas, quién solicita permiso para dar funciones de acróbatas en una casa de la colonia Morelos, el cual se le concede al pagar la cuota que señala la ley. ${ }^{75}$ Lo mismo sucedía para quienes querían dar exhibiciones de figuras de cera, figuras en movimiento, mesas de tiro al blanco o funciones de títeres. De estas últimas había compañías pequeñas integradas por dos o tres titiriteros que se presentaban en

\footnotetext{
${ }^{70}$ AHDF, Fondo: Ayuntamiento; Sección: Diversiones públicas; vol. 807; exp. 1316.

${ }^{71}$ María Dolores Lorenzo Río, op. cit., pág. 247.

${ }^{72}$ William H. Beezley, Judas en el Jockey Club, México, El colegio de San Luis-CIESAS, 2010, pág. 82.

73 Ibidem, pág. 96.

74 Juan Felipe Leal, et. al., Anales del cine en México, 1895-1911. Volumen 5: 1899: iA los barrios y a la provincia!, Voyeur, México, 2003, pág. 19.

${ }^{75}$ AHDF, Fondo: Ayuntamiento; Sección: Diversiones Públicas; vol. 806; exp. 1095.
} 
las calles o ferias; y otras más grandes de más de doce titiriteros que se presentaban en teatros establecidos. ${ }^{76}$ Los permisos se solicitaban desde el Porfiriato, y cumplían una doble función: establecer un control sobre las diversiones públicas y la generación de recursos económicos.

Asimismo los espectáculos eran promovidos a partir de programas de mano que se repartían en las calles por niños gritones que iban con "orquesta, tambores, cornetas, para anunciar corridas de toros, circo, funciones de cinematógrafo o teatro con la finalidad de llamar la atención y despertar curiosidad". ${ }^{77}$ También se colocaban carteles en las paredes de las calles, afuera de los teatros, circos, plazas de toros y palenques.

Las diversiones para las clases populares se desarrollaban por lo regular en los espacios públicos. "A las cuatro o cuatro y media, al toque de una marcha ejecutada por la murga salían los volantines y cirqueros y a la cabeza el famoso payaso, quien hacía al público grotescos saludos y presentaba a sus chicos, como él llamaba a todos los de la comparsa". ${ }^{78}$ Múltiples actividades se realizaban en la calle, las cuales cualquier persona por estar caminando en ella podía disfrutar:

Los transeúntes se reunían frecuentemente a escuchar música alrededor de fonógrafos que eran llevados por hombres vestidos con trajes humildes. También se aglutinaban en las banquetas para admirar los desfiles de payasos y animales, que anunciaban las presentaciones circenses en las carpas que se instalaban provisionalmente en plazas y plazuelas de la capital. ${ }^{79}$

Los fonógrafos eran disfrutados por toda la gente que andaba en la calle, "distraía los domingos a todos los campesinos o indígenas que llegaban a la metrópoli a vender sus mercancías. Los programas consistían primero en melodías de ópera,

\footnotetext{
${ }^{76}$ William H. Beezley, La identidad nacional mexicana: la memoria, la insinuación y la cultura popular en el siglo XIX, México, El colegio de la frontera norte-El colegio de San Luis- El colegio de Michoacán AC, México, 2008, pág. 181

${ }^{77}$ Aurelio de los Reyes, iTercera llamada, tercera! Programas de espectáculos ilustrados por José Guadalupe Posada, Instituto Cultural de Aguascalientes, México, 2005, pág. 13.

${ }^{78}$ Antonio García Cubas, El libro de mis recuerdos, Patria, México, pág. 255.

${ }^{79}$ Mario Barbosa Cruz, El trabajo en las calles, op. cit., pág. 105.
} 
discursos políticos y con posteridad se podían escuchar poemas de los "modernistas". 80

También era muy común encontrar a payasos, equilibristas, malabaristas, amaestradores de animales caminando por las calles anunciando las funciones de circo, espectáculo que en sí ya era una diversión, ya que acaparaban la atención de la gente realizando muestras de las gracias que podrían ver en el circo. Merolicos, vendedores de productos milagro, charlatanes pseudocientíficos, hombre mosca escalando a la cima de la catedral metropolitana, intrépidos jóvenes trepando un palo encebado con el afán de alcanzar un premio, personajes con canarios predicadores de la suerte, violinistas, organilleros, marimberos y cancioneros recorren las calles tocando melodías a cambio de unas monedas. La quema de judas en los Sábados de Gloria eran eventos que conglomeraba a la población, sin mencionar la variedad de tradiciones litúrgicas y ferias que acontecían cada semana en diferentes partes de la ciudad y las celebraciones cívicas como el 5 de mayo y la Independencia.

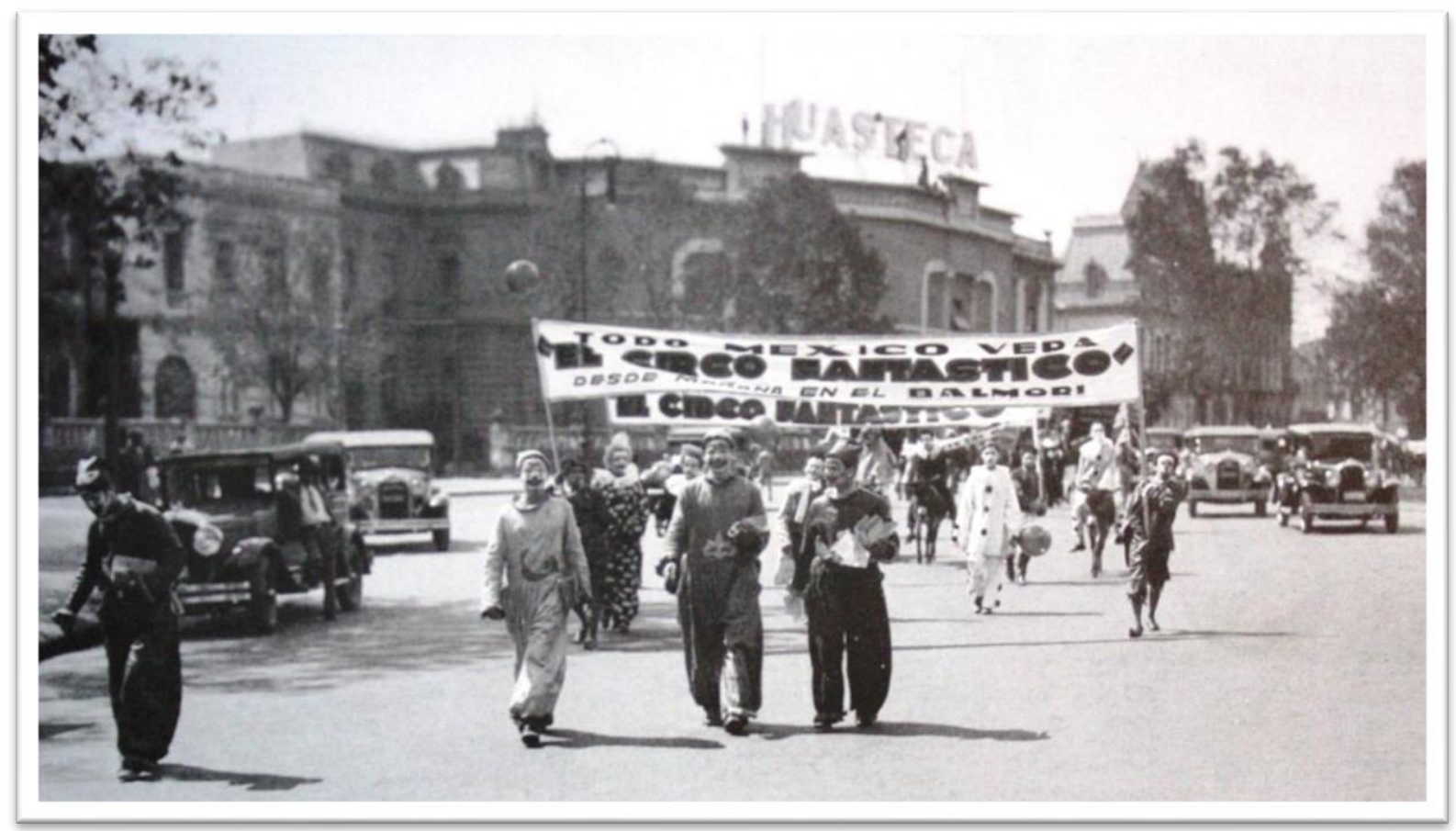

Artistas de circo anunciando el espectáculo por las calles de la ciudad.

Fuente: Fototeca INAH.

\footnotetext{
${ }^{80}$ Aurelio de los Reyes, Los orígenes del cine, op. cit., pág. 55.
} 
Como atestiguan los documentos del Archivo Histórico del Distrito Federal, en la sección de Diversiones Públicas, la oferta de recreaciones en la ciudad de acuerdo a los permisos solicitados al Ayuntamiento, algunas estaban estrechamente vinculadas con las fiestas patronales de las iglesias más importantes, en donde llegaban ferias y los empresarios solicitaban permiso para establecer mesas de tiro al blanco, juegos de argollas, trenes de caballitos, entre otros.

Asimismo, también había otro tipo de diversiones con fines educativos y científicos, como el caso de un empresario que en 1901 pide permiso para abrir un museo o exposición de figuras de cera, referentes a la anatomía, fisiología, patología, obstetricia, embriología y otras ciencias médicas:

Como quiera que aunque se trata de un Museo propiamente científico, la naturaleza de la exhibición no es propia de damas ni de niños, por las explicaciones verbales que se darán a los visitantes sobre las funciones de los órganos del cuerpo humano, advertimos que la entrada quedará absolutamente prohibida a menores de diecisiete años así como a las señoras.

Strassburguer \& Co. ${ }^{81}$

Otro entretenimiento importante fue el cinematógrafo, traído a México en 1896 directamente de Francia por los ayudantes de los hermanos Lumiere, ${ }^{82}$ fue un espectáculo que fascinó al público, sin embargo "hacia 1900, al término de su primer periodos ascendente, la escasa duración de las películas (o vistas en movimiento), su carácter primordialmente documental y el que se exhibieran casi siempre en blanco y negro provocaba hastío", ${ }^{83}$ por lo que el público en aquel momento prefirió el teatro de revista, "mientras los exhibidores [cinematógrafos] que se aferraban al negocio tuvieron que irse, para sobrevivir, a pequeños pueblos donde no tenían competencia de otros entretenimientos [...] Esto duró unos tres años. Y entonces, el cine revivió de sus cenizas", 84 y se convirtió en uno de los entretenimientos favoritos de la población. El cinematógrafo y el teatro de género

\footnotetext{
${ }^{81}$ AHDF, Fondo: Ayuntamiento; Sección: Diversiones públicas; vol. 805; exp. 1156.

${ }^{82}$ Aurelio de los Reyes, Los orígenes del cine, op cit., pág. 40.

${ }^{83}$ Ángel Miquel, Disolvencias. Literatura, cine y radio en México (1900-1950), FCE, México, 2005, pág. 19.

${ }^{84}$ Idem.
} 
chico fueron de las diversiones más recurridas por la población, muchas veces los empresarios tenían sus carpas y alternaban la oferta de los dos espectáculos. En documentos del Archivo General de la Nación se encuentran títulos de zarzuelas con la anotación "argumento cinematográfico", 85 lo que demuestra que se retomaron las puestas en escena para la realización de películas.

Para el público, el cinematógrafo era a la vez una diversión y una "maravilla de la ciencia". Primero lo contempló quien pudo pagar cincuenta centavos tanda de ocho películas, lo que molestó a las "familias acomodadas", que exigieron representaciones "de gala" exclusivas cada jueves con un programa de doce vistas por un peso. Al reducirse los precios a veinticinco centavos, pudo conocerlo un sector más amplio. ${ }^{86}$

Desde 1915 hasta la década de 1950 aparecieron diversos cines en los que se acostumbraba bailar una tanda musical en los intermedios que duraban casi una hora, mientras llegaba la película que se había exhibido antes en otro cine, ya fuera con música en vivo o con fonógrafo. ${ }^{87}$ El surgimiento de nuevos entretenimientos hizo posible su mezcla entre ellos mismos, como lo fue el cine con los espectáculos de variedades, piezas musicales y bailes.

Uno de los entretenimientos más populares de la población capitalina fue el baile, primordialmente el danzón, para el cual, la inauguración en 1920 del centro de esparcimiento nocturno, Salón México, fue muy apreciado para el público. "En su concepción como baile de salón, este género musical concibió una atmósfera masificada de relajamiento a la que acudiría gente de todos los sectores sociales [...] La llegada del danzón a la ciudad de México implicó un primer momento de proyección de las creaciones cubanas en la gran urbe mexicana". ${ }^{88}$ Con el éxito del Salón México se incrementaron los centros nocturnos entre 1920 y 1940, otros de los más importantes fueron el Colonia, el California Dancing Club y Los Ángeles.

\footnotetext{
${ }^{85}$ Aurelio de los Reyes, Cine y sociedad en México, 1896-1930. Volumen I, Vivir de sueños, op. cit., pág. 7.

${ }^{86}$ Ibidem, pág. 25.

${ }^{87}$ Amparo Sevilla, Los templos del buen bailar, CONACULTA, México, 2003, pág. 60.

${ }^{88}$ Gabriela Pulido, Mulatas y negros cubanos en la esfera mexicana, 1920-1950, INAH, México, 2010, pág. 90, 91.
} 


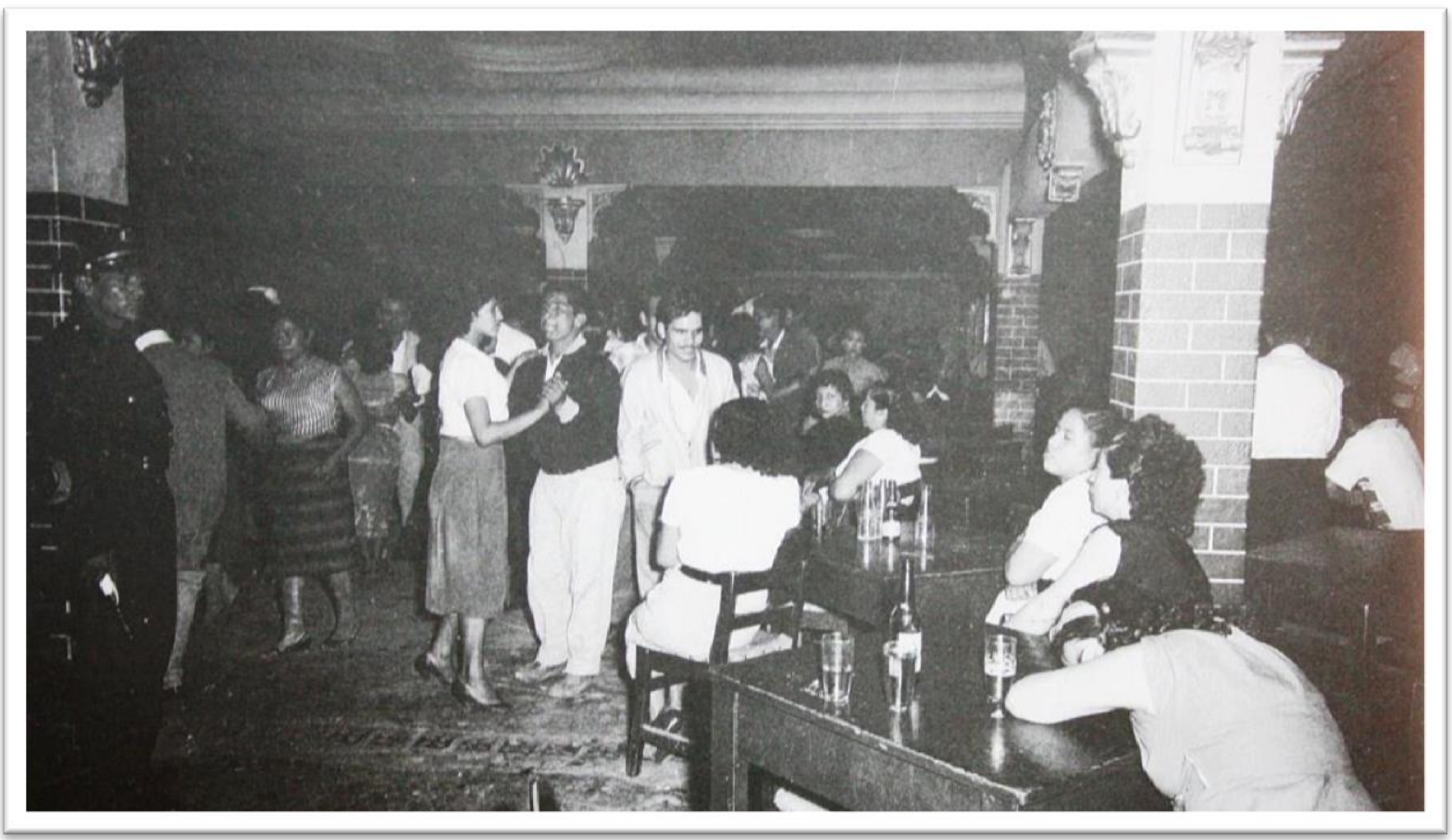

Los salones de baile también fueron lugares predilectos para el entretenimiento de la población.

Fuente: Fototeca INAH.

Otra de las diversiones públicas más importantes en la ciudad fue la fiesta brava, "a ella acudían diversos representantes del espectro social, desde la aristocracia política hasta los sectores populares, pasando por la creciente clase media urbana. En varios cosos taurinos, como el de San Rafael, el de San Pablo, el del Huizachal o el de Bucareli, los habitantes de la ciudad podían pasar las tardes de domingo disfrutando este espectáculo". ${ }^{89}$ En un programa atribuido a José Guadalupe Posada de 1909, se anuncia la lucha entre el toro Nero de la ganadería española Muruve, y un león, de un espectáculo de variedades ecuestres organizado por la misma plaza, se decía que si el toro vencía, lucharía contra un cocodrilo. ${ }^{90}$

La sociedad se divertía en espectáculos taurinos, como lo hacía también, según su accesibilidad social, en los cinematógrafos, hipódromos, teatros, entre otras diversiones.

\footnotetext{
${ }^{89}$ Ricardo Pérez Montfort, “Circo, teatro y variedades”, op. cit., pág. 99.

${ }^{90}$ Aurelio de los Reyes, iTercera llamada, tercera!, op. cit., pág. 35.
} 
El público taurómaco y el aficionado a los espectáculos teatrales, por el sistema de tandas, son gemelos por sus gustos y pareceres, caracterizándose ambos por la intercadente turbación del juicio. Si el primero vocifera y se enloquece ante las sangrientas escenas que se desarrollan en la arena, el segundo se enloquece y grita ante el aniquilamiento del arte en las tablas. ${ }^{91}$

En la década de 1930 los aficionados a la fiesta brava cambiaron notablemente sus hábitos, ya que podían escuchar el espectáculo desde la comodidad de su hogar. "En la estación de radio XEW Alfonso Sordo Noriega transmitía desde el burladero la corrida de toros en su programa "Qué fácil es ver los todos desde la barrera". ${ }^{92}$ Más tarde, en 1946, se inauguró la Monumental Plaza México con una capacidad de 50 mil espectadores, lo que demuestra el gran gusto por este esparcimiento.

Asimismo se podía disfrutar de otros tipos de entretenimiento como "las peleas de gallos en el gran palenque de la Vencedora, las carreras de caballos en los hipódromos del rancho de Nápoles, de Peralvillo o de Indianilla, ${ }^{93}$ diversiones que evidencian el gusto de la sociedad por las actividades que involucran apuestas.

Existía también un variado centro de espectáculos llamado "Golden Park", ${ }^{94}$ muy frecuentado por familias, que iban a recrearse con multitud de atractivos que un empresario había logrado reunir y por los que cobraban un solo precio de entrada; las distracciones consistían en salones de baile, funciones de circo, de teatro, columpios, títeres, voladores, boliches y billares. Se mantenía abierto prácticamente todo el día, ofreciendo entretenimiento para público de todas las edades.

Los pudientes personajes porfirianos y sus amigos extranjeros se divertían organizando carreras de automóviles, subiendo en los primeros aeroplanos en los llanos de Balbuena, jugando golf, cricket o polo, en estas actividades ocupaban su tiempo de ocio. ${ }^{95}$ En 1920, debido a que al entonces presidente Adolfo de la

\footnotetext{
${ }^{91}$ Antonio García Cubas, op. cit., pág. 9.

${ }^{92}$ Eduardo Flores Clair, op. cit., pág. 165.

93 Ricardo Pérez Montfort, “Circo, teatro y variedades”, op. cit., pág. 108.

${ }^{94}$ Armando de Maria y Campos, Las tandas del principal, op. cit., pág. 144.

${ }^{95}$ Ricardo Pérez Montfort, “Circo, teatro y variedades”, op. cit., pág. 112,
} 
Huerta le gustaba la música clásica y la ópera, se multiplicó este tipo de espectáculos en la ciudad. ${ }^{96}$ Estas recreaciones sólo eran posibles para el grupo de élite, el pueblo por lo general no tenía acceso económico ni social para poderse divertir de esta manera.

Otros medios de distracción de los capitalinos fueron los deportes, como el beisbol, futbol, boxeo, entre otros, para los cuales se tuvo que construir infraestructura en la ciudad, lo cual despertó el gusto de la población, pero de una manera más lenta.

En 1918 se inauguró el parque Reforma, "construido en terrenos cercanos al Monumento a la Independencia, para el pleno disfrute del beisbol [...] Para 1921 se organizó el Campeonato del Centenario en el parque Unión, edificado en la actual Plaza de la República". ${ }^{97}$ En lo que se refiere al futbol,

en septiembre de 1930, por el rumbo de La Piedad, se ocuparon por primera vez las gradas del campo "Necaxa", un moderno estadio que tenía capacidad para más de 15 mil espectadores [...] Emilio Azcárraga, José Ramón Ballina y Anacaris Peralta propusieron, en 1943, a las autoridades del Distrito Federal la construcción de un enorme estadio, el cual nunca llegó a realizarse. Sin embargo, el proyecto fue retomado por el acaudalado Negib Simón, quien construyó el estadio de la Ciudad de los Deportes, el cual tenía capacidad de 60,000 espectadores y abrió sus puertas por primera vez en 1946. Con el paso del tiempo el futbol se convirtió en el deporte más popular. ${ }^{98}$

En la capital se practicaban un número mayor de deportes, ocupando espacios determinados y manteniendo una clientela predominantemente de clase alta, como por ejemplo: frontón, tenis, basquetbol, rugby, cricket, charreadas, automovilismo, tiro, natación, deportes hípicos, entre otros.

Entre las diversiones más populares para las clases bajas a partir de la década de 1930 se encuentra la lucha libre. El 21 de septiembre de 1933 "en la Arena México del Distrito Federal, se celebró el primer encuentro entre

\footnotetext{
${ }^{96}$ Aurelio de los Reyes, Cine y sociedad en México, 1896-1930. Vol. Il. Bajo el cielo de México, op. cit., pág. 38.

${ }^{97}$ Eduardo Flores Clair, op. cit., pág. 166.

${ }^{98}$ Ibidem, pág. 167.
} 
profesionales". ${ }^{99}$ Aunque los antecedentes se remontan a 1863 , con el primer luchador mexicano, Antonio Pérez de Prían, quien estuvo presentando números acrobáticos y de fuerza en los circos y en las plazas de toros. En 1910 se presentaban encuentros en el teatro Principal, sin embargo es hasta la tercera década del siglo xx cuando cobra mayor fuerza esta recreación. ${ }^{100}$ La lucha libre siempre estuvo ligada a los sectores populares. "En la arena, como en la carpa, no existen espectadores pasivos: éstos interactúan en el desarrollo del espectáculo a través de un diálogo recíproco con los atletas, incitándolos y haciéndolos partícipes, por medio de gritos, de sus preferencias durante el desarrollo de las acciones". ${ }^{101}$ De esta manera, los espectadores se convierten en parte del espectáculo que los entretiene; no tendría la misma importancia la lucha libre si no fuera por la intervención de quien los observa, y este público, a su vez, desahoga todo lo reprimido mediante esa interacción directa.

Otro de los entretenimientos que va ligado con la lucha libre y los sectores populares fue el boxeo, desde sus inicios tuvo una cultura de calle y se relacionó al sector urbano popular y a su vida de barrio. Precisamente sirve de ejemplo el barrio de Tepito como fuente de grandes boxeadores. Durante la década de 1950 "Una pelea del Ratón [Macías] se convertía en un pretexto para reunirse en casa de todos aquellos que tenían un aparato. Cada uno pagaba 5 o 10 centavos y ese dinero servía a los propietarios para cubrir los abonos del televisor". ${ }^{102}$ Esto nos da muestra de las relaciones que se forjaban al momento de compartir el tiempo libre, entreteniéndose con diversiones con las que se identificaban los sectores populares urbanos. Y si se optaba por apreciar el espectáculo de manera directa, los fines de semana por la noche, los aficionados capitalinos se congregaban en las puertas de las arenas: Nacional, Degollado y Libertad. Para 1943, debido a que el número de seguidores había aumentado, se construye la arena Coliseo, cuya capacidad rebasaba las seis mil localidades.

\footnotetext{
99 Tiziana Bertaccini, Ficción y realidad del héroe popular, CONACULTA, México, 2001 pág. 77.

100 Ibidem, pág. 78.

101 Ibidem, pág. 83.

102 Ibidem, pág. 125.
} 
Otro espectáculo que se sumó en la década de 1930 fue el burlesque. Por su carácter pornográfico se representó de manera restringida en pocos teatros, como el Tívoli (que inicialmente fue arena de lucha libre) y el Apolo. "El burlesque también tenía nexos con la revista, pues a menudo se insertaban sketschs cómicos -un poco vulgares- entre cada número de desnudo, que muchas veces tocaban temas de actualidad o crítica social". ${ }^{103}$

La mayor parte de las formas de recreación se encontraban en la calle, sin embargo con la llegada del radio las familias no necesariamente tenían que salir de sus casas para entretenerse. "La XEW, inaugurada en 1930 bajo la égida de Emilio Azcárraga, copia modelos norteamericanos para la realización de programas dirigidos especialmente al círculo familiar", ${ }^{104}$ de esta manera la población tiene la oportunidad de escuchar desde la comodidad de su hogar canciones, chistes, novelas, entre otras cosas que formaran parte de la industria del entretenimiento, de la cual se hablará más adelante.

\section{EL TEATRO EN LA CIUDAD}

El siglo Xx comenzó demoliendo el gran teatro Nacional, también conocido como de Santa Anna, Gran Teatro o Imperial, el 14 de diciembre de 1900, que fue tan importante para la vida teatral del siglo XIX, incluso tuvo más capacidad que el actual Palacio de Bellas Artes; sin embargo, fue demolido para ampliar la avenida 5 de mayo, como respuesta a las necesidades de urbanización de la ciudad de México. Lo cual no quiere decir que el espectáculo teatral haya bajado su popularidad, al contrario, fue una de los esparcimientos más concurridos por la población, tanto en los grandes recintos como en las carpas o jacalones.

\footnotetext{
${ }^{103}$ Pablo Dueñas, op. cit., pág. 26.

${ }^{104}$ Socorro Merlín, Vida y milagros de las carpas, pág. 21.
} 


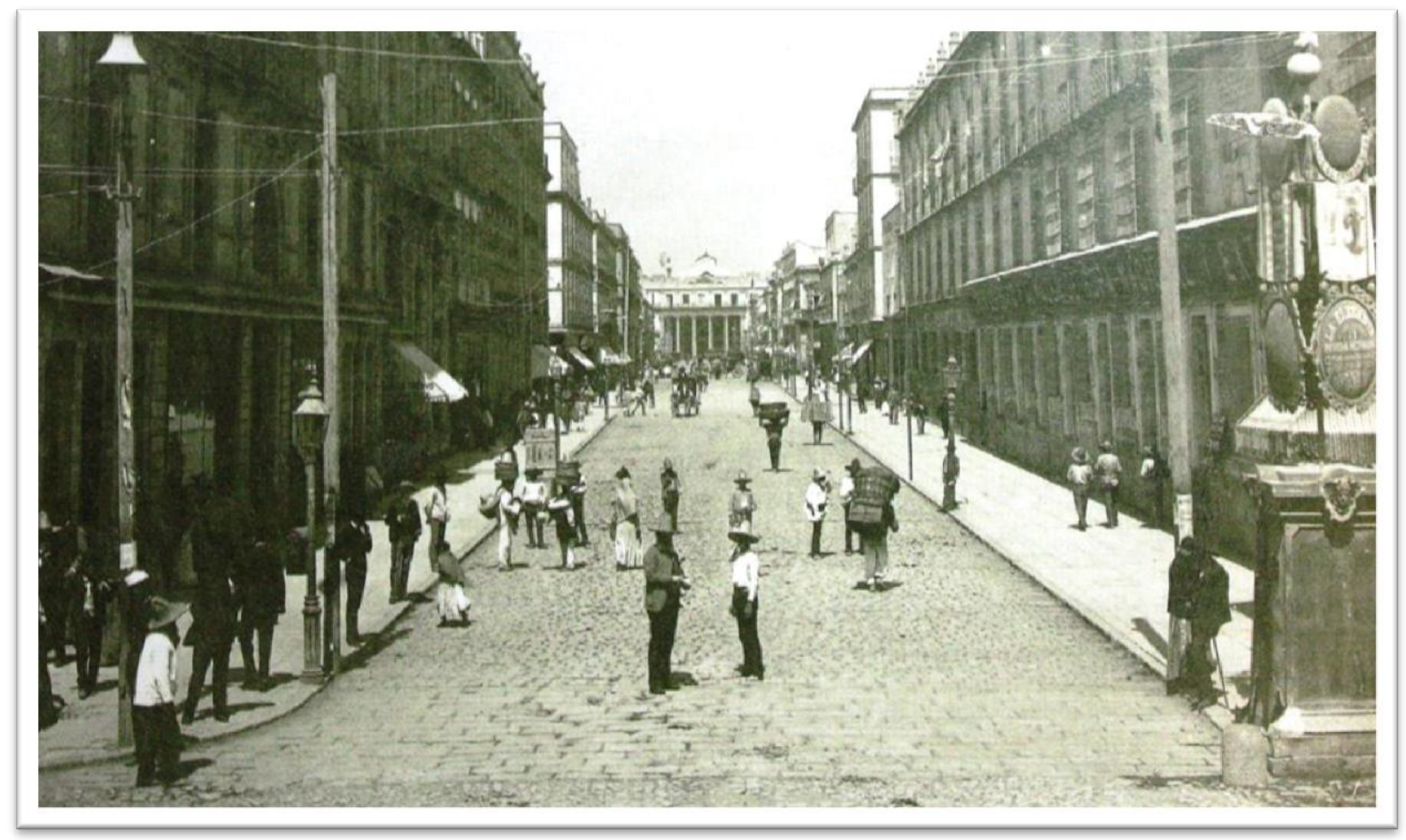

Calle 5 de mayo, una de las más importantes de la ciudad durante el Porfiriato, al fondo se aprecia el Teatro Nacional, que fue demolido al iniciar el siglo xx para ampliar la calle.

Fuente: "Calle 5 de mayo", Álbum la capital de México, Biblioteca Francisco Xavier Clavijero.

El surgimiento de las tandas como oferta teatral fue del gusto de la mayoría de la población y estuvo al alcance de todos los sectores, lo cual se dará a conocer ampliamente en otro apartado. Por el momento quisiera hacer un repaso sobre cómo era la vida teatral en la ciudad de México.

A principios de siglo los teatros con mayor auge fueron: el Principal, el Lírico, el Arbeu, el Esperanza Iris y el María Guerrero, todos ellos construcciones decimonónicas. En éstos se montaban las obras con artistas de primera clase, los autores más reconocidos y los músicos más famosos. La población acudía a su teatro favorito, pero sin lugar a dudas el más concurrido en aquella época fue el Principal, que funcionó hasta 1931 cuando sufrió un incendio. 


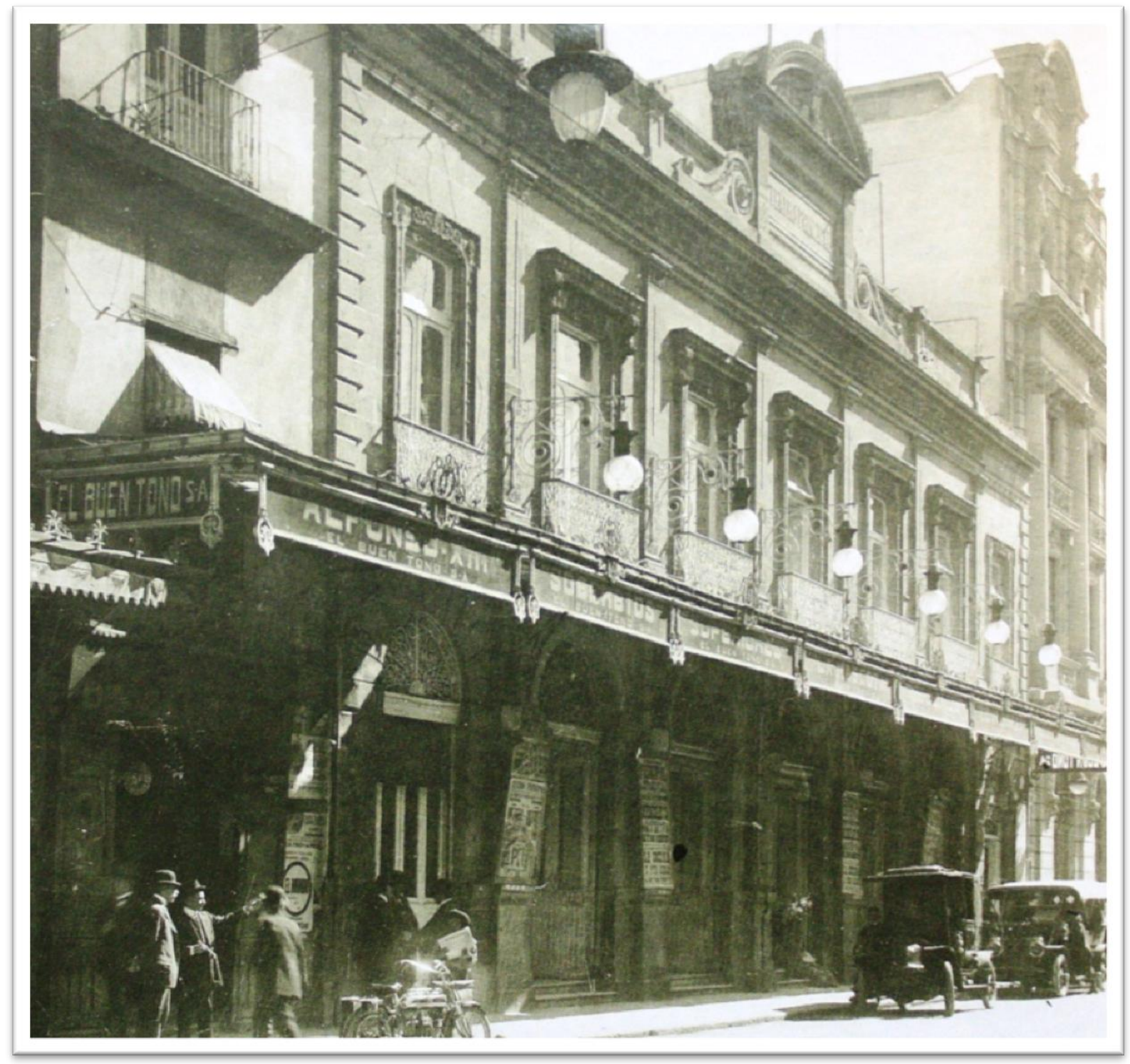

Teatro Principal, uno de los más importantes de la ciudad hasta 1931 cuando se incendió.

Fuente: Fototeca AGN.

Otro de los teatros populares y que ofrecía un espectáculo más diverso fue el teatro Circo Orrin, que empezó utilizando una carpa establecida momentáneamente en la Plazuela del Seminario en 1881, cinco años después se trasladó a la Plaza de Santo Domingo, y por fin en 1891 se instalaron como teatro Circo Orrin, construido en la plaza de Villamil. "Durante esos 29 años se ofrecieron 13960 funciones a las que concurrieron unos 13 millones de espectadores a 
aplaudir a unos tres mil artistas. Sobra decir que la estrella del Circo Orrín durante muchos años fue Ricardo Bell". ${ }^{105}$

Mientras tanto, los servicios urbanos se acondicionaban a las actividades de la población, incluso a su esparcimiento, como lo demuestra el caso del teatro Esperanza Iris, que llegó a ofrecer el servicio de tranvías nocturnos para transportar a las personas que vivían en las orillas de la ciudad. ${ }^{106}$ Además había otras opciones de esparcimiento aún después de las funciones teatrales, las cantinas y bares eran frecuentados, como lo comenta Armando de Maria y Campos:

Entre tanda y tanda, antes o después de ir al Principal o al Arbeu, los tandófilos se echaban entre pecho y espalda sus tandas de licores [...] El México que gustaba de divertirse, alternaba las tandas del Principal o del Arbeu con las tandas de copas en el Salón Bach, la Concordia, La Bella Unión o la cervecería Sennor. La nocturna existencia de la urbe capitalina ofrecía a fines o principios de siglo características inconfundibles. ${ }^{107}$

Asimismo, durante las primeras horas de la madrugada, los actores, autores, apuntadores, tramoyistas, divas y admiradores acostumbraban acudir a los cafés bohemios. Uno de ellos fue el Café Inglés, ubicado frente al teatro Principal, sitio predilecto de José F. Elizondo y su círculo de allegados. Otro lugar fue el restaurante Maisón Doré, situado en la calle de San Francisco. Cerca de la Plaza de Villamil se encontraba el Café del Tamalito, frecuentado por cómicos y divas. El Café Manrique también era de los preferidos, ubicado en la calle que hoy se llama República de Chile; otros fueron: la Concordia, en la esquina de Profesa y $2^{\underline{a}}$ de Plateros (Madero, esquina Isabel la Católica), el Café Madrid, El Globo, el Café París, en la calle 5 de mayo. ${ }^{108}$ Ahí permanecían conviviendo hasta entrada la madrugada.

Ese era el ambiente que se vivía en los teatros durante el Porfiriato, la población tenía gran apego a las tandas representadas en los teatros, y las clases altas mantenían un pensamiento conservador acerca de ellas, como lo narra el

\footnotetext{
${ }^{105}$ Luis Reyes de la Maza, Cien años de teatro en México, SEP, México, 1972, pág. 158.

${ }^{106}$ Eduardo Flores Clair, op. cit., pág. 163.

${ }^{107}$ Armando de Maria y Campos, Las tandas del principal, op. cit., pág. 58.

108 Pablo Dueñas, op. cit., pág. 49-52.
} 
cronista Armando de Maria y Campos: "Al llegar al hogar, las familias "decentes" notaban la ausencia del primogénito, o de alguno de los jóvenes "hombres de la casa". La madre ponía el grito en el cielo y el padre fruncía el gesto: se miraban, y casi sin hablar, se comprendían: jlas tandas! El padre pensaba para sus adentros: ¡con tal que no le sorba el seso alguna pelandusca!". ${ }^{109}$

Durante la década de la lucha armada los espectáculos en la ciudad disminuyeron ya que la población prefería no salir de sus casas, muchos le temen a la leva; la estabilidad y el crecimiento de la ciudad y de todo el país se detiene, incluso hay población que migra de la ciudad hacia lugares que consideran más seguros. La vida social de la población se paraliza, y junto con ella, el ambiente teatral, como nos lo narra Salvador Novo:

Al estallar ésta [la Revolución] la corriente que los nutría y justificaba (a los locales para el teatro) se desvió de sus cauces normales y apacibles. ¿Quién, con los tiroteos, iba a salir de noche? Con los descarrilamientos ¿a emprender giras? Los grandes cortinajes rojos empezaban a empolvarse, a carcomerse en el olvido los decorados, a velarse de telarañas las butacas y los camerinos aromados de flores secas. $Y$ a permanecer cerrados, desiertos y en acelerado deterioro, los muchos grandes teatros que vivieron noches gloriosas durante la opereta en el porfiriato. ${ }^{110}$

Una vez pasada la Revolución, el teatro cobra nuevamente importancia entre la población, incluso "entre 1918 y 1925 aparecieron más de 20 teatros nuevos que sumaron sus butacas a los viejos coliseos decimonónicos"111 y en 1921 se da permiso para anunciar funciones de carpa en autos por las calles de la ciudad, ${ }^{112}$ lo cual demuestra la demanda por el espectáculo, que para entonces ya era diferente al ofrecido durante el Porfiriato.

Por otra parte, también se instalaban las carpas o jacalones, que existían desde la segunda mitad del siglo XIX, se idearon para aquella población que no podía asistir a los teatros de elite. Casi ninguna carpa tenía ubicación fija, se situaban en los terrenos o plazuelas disponibles. Hubo algunas que se

\footnotetext{
${ }^{109}$ Armando de Maria y Campos, Las tandas del principal, op. cit., pág. 83.

${ }^{110}$ Salvador Novo, citado por Carlos Monsiváis, "Notas sobre la cultura mexicana en el siglo Xx", en Historia general de México, El Colegio de México, México, 2000, pág. 1067.

${ }^{111}$ Eduardo Flores Clair, op. cit., pág. 164.

112 AHDF, Fondo: Ayuntamiento; Sección: Diversiones públicas; vol. 808; exp. 1387.
} 
mantuvieron en su sitio por varios años, como las de los empresarios Pepe Herrera "Procopio" o el famoso ventrílocuo Paco Miller, tenían varias sucursales con distintos nombres, incluso en diversos estados de la República, por lo que su grupo de artistas exclusivos hacían giras con mucha frecuencia. Algunos fueron trashumantes, viajaron con todo y sus manejables estructuras por varias poblaciones como sucedió con la compañía de Paco Miller, que incluso llegó a utilizar vagones de ferrocarril completos para efectuar sus viajes con toda su propiedad. $^{113}$

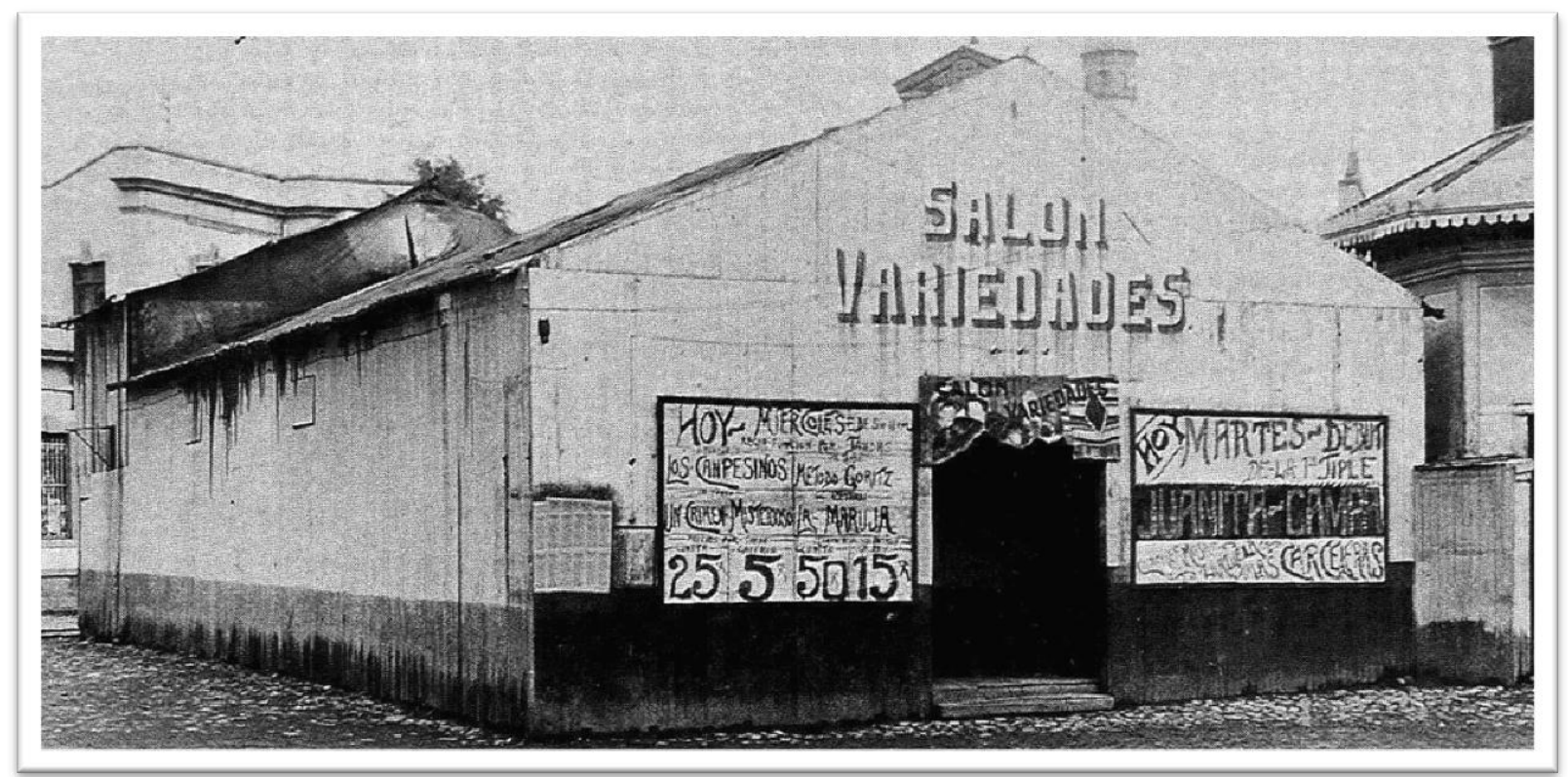

Carpa establecida de manera provisional.

Fuente: Colección de Gustavo García.

En las carpas se ofrecían funciones de circo, títeres, zarzuelas importadas de España, además de atracciones musicales, números ecuestres, entre otro tipo de entretenimientos que disfrutaban, por lo general, los grupos populares. ${ }^{114}$ Las carpas heredan del circo gran parte de lo que más tarde sería conocido como espectáculo carpero. Del circo retoma y modifica al payaso, convirtiéndose en cómico de carpa y quedan incluidas en el espectáculo la magia y la

\footnotetext{
${ }^{113}$ Pablo Dueñas, op. cit., pág. 57.

${ }^{114}$ Socorro Merlín, Vida y milagros de las carpas, op. cit., pág.65.
} 
prestidigitación. Es la carpa, pues, el circo de para adultos. ${ }^{115}$ "Para los acróbatas, maromeros y animales adiestrados que se presentaban en la vía pública se destinaron, entonces, los jacalones y las plazas de toros. En los escenarios del teatro Nuevo México y de otros teatrillos de barrio, como La Democracia y el Guerrero, se presentaron obras para los grupos, por ejemplo, para obreros y artesanos de la capital". ${ }^{116}$ En estos lugares también se representaban pastorelas, obras de teatro o pantomimas ligadas al calendario litúrgico como las fiestas decembrinas, la cuaresma o la fiesta de todos los santos. ${ }^{117}$

Los escenarios de las carpas se utilizaban para ofrecer diferentes tipos de espectáculos como: equilibristas, contorsionistas, pantomimas, acróbatas, marionetas, magos, prestigitadores, cantantes, bailarines, músicos, pulgas amaestradas, entre otros números. ${ }^{118}$ "En el Salón Domínguez el público veía a una mujer de 65 centímetros, sin piernas ni brazos, que bordaba, cosía, disparaba el rifle, bailaba el jarabe tapatío y ejecutaba labores difíciles". ${ }^{119}$ Este tipo de espectáculos eran muy apreciados por el público, provocando la saturación de las carpas.

Soledad Arcaydo, payaso y titiritero, fue uno de los primeros nombres registrados como propietario de una carpa o jacalón. ${ }^{120} \mathrm{~A}$ las carpas también se les conocía con el nombre de maromas. "Estos lugares eran amplios corralones con piso de tierra, apenas acondicionados con graderías de maderos viejos y techos de tejamanil, aunque algunos de ellos tenían como techo el propio cielo [...] Gente de trabajo ocupaba la mayor parte de las graderías: artesanos, herreros, carpinteros, pequeños comerciantes". ${ }^{121}$ Al terminar la función de cómicos y números acrobáticos el espacio solía transformarse en una pista de baile.

Las carpas se localizaban por todos los rumbos de la urbe, pero las más populares eran las que se situaban en las calles cercanas a lo que ahora es el eje

\footnotetext{
115 Romina Martínez, “¡Corre...! ¡Va a comenzar la tanda...! Un acercamiento a la diversión carpera en Guadalajara, 1920-1940”, en Takwa, no. 9, primavera 2006, pág. 110.

${ }^{116}$ María Dolores Lorenzo Río, op. cit., pág. 240.

117 Ibidem, pág. 229.

${ }^{118}$ Eduardo Flores Clair, op. cit., pág. 164.

${ }^{119}$ Aurelio De los Reyes, Cine y sociedad en México 1896-1930. Volumen I Vivir de sueños, pág. 86.

${ }^{120}$ Luis Reyes de la Maza, Circo, maroma y teatro, UNAM, México, 1985, pág. 84.

${ }^{121}$ Amparo Sevilla, Los templos del buen bailar, op. cit., pág. 43.
} 
central. Con distancias que fluctuaban entre los doscientos o trescientos metros se encontraban instaladas las carpas. ${ }^{122}$ En 1924 en la ciudad había veintidós carpas que ofrecían funciones de variedades. ${ }^{123}$

Una de las carpas más famosas fue La mariposa, situada en la calle General Anaya, cerca de la plaza de La Merced, su propietario don Pepe Herrera, Procopio, también fue payaso de circo, tenía varias sucursales dispersadas en diversos lugares de la capital, la Procopio, la Polita, nombre tomado de la esposa de don Pepe Huerta, la Principal y otras como el Teatro Pierrot, cerca de la calle Laguna de Pátzcuaro. La mariposa fue la más grande de su tiempo, tenía lunetas y galería, un gran foro y camerinos individuales aunque muy estrechos. ${ }^{124}$

El declive de las carpas en la ciudad devino en la década de 1950. Debido a la estabilización social, económica y política, la imagen de la urbe cambia de manera radical, "Uruchurtu no quiere mal aspecto de la ciudad, la modernidad a la que ha entrado el país no lo permite. Los jacalones o carpas de lona pobres y de mal aspecto desaparecen de las calles principales, para dejar sólo a los teatros para revista y variedad Cervantes, Follies, Lírico". ${ }^{125}$ Lo trashumante de las carpas desaparece, ya no hay espacio ni permiso para su peregrinar por las plazuelas, los lotes baldíos son ganados por las inmobiliarias, si se pretende continuar con el teatro de revista tendrá que ser en lugares establecidos. Además "era difícil sostenerlas, porque el público empezó a gustar de otras formas de ocupar su tiempo libre y porque ya no había espacio donde ubicarlas, por la expansión de la mancha urbana, la apertura de nuevas avenidas y la pavimentación de calles". ${ }^{126}$ Muchos fueron los factores que hicieron desaparecer las carpas, pero antes tenemos que hablar más a fondo acerca de su particular origen y su desarrollo.

\footnotetext{
${ }^{122}$ Fidel Ángel Espino, Clavillazo. Cuando las manos hablaron, Diana, México, 1989, pág. 173.

${ }^{123}$ Aurelio de los Reyes, Cine y sociedad en México, 1896-1930. Vol. Il. Bajo el cielo de México, op. cit., pág. 263.

${ }^{124}$ Pedro Granados, op. cit., pág. 54.

${ }^{125}$ Socorro Merlín, Vida y milagros de las carpas, op. cit., pág. 37.

126 Ibidem, pág. 38.
} 


\section{ORIGEN Y DESARROLLO DEL TEATRO POPULAR}

Una vez contextualizando el espacio, el modo de vida de la población capitalina y la oferta de diversiones públicas en la ciudad, esta investigación aterriza en los antecedentes inmediatos de lo que en este caso nombraremos "teatro popular", la manera de cómo se fue concibiendo y sus características particulares orientadas a la población de la ciudad de México.

La vida teatral se desarrolló siguiendo las normas morales y los criterios sanitarios de la época, se tenían que respetar para el establecimiento y funcionalidad de las múltiples diversiones según las normas de higiene vigentes en la ciudad, por lo que se analizarán qué tanto se respetaron y hasta qué punto dejaron de ser prioritarias estas normas para preocuparse por otras de diferente índole.

En otro apartado se tratará de conocer cómo fue el sistema normativo y la libertad de expresión en el teatro popular según la crítica política realizada. Se ilustrará cómo se regían las diversiones públicas por medio de la legislación vigente en esa temporalidad, además de conocer de qué manera funcionaba la Comisión de Diversiones Públicas, que se encargaba de conceder los permisos correspondientes para representar cualquier tipo de entretenimiento en la ciudad. Asimismo es importante dar cuenta del control que ejercía el Ayuntamiento en las representaciones teatrales, preocupándose por la moralidad y la libertad de expresión, ya que constantemente las obras eran censuradas y los autores y actores resultaban perseguidos debido a la inmoralidad y a la crítica política contenida en las obras en las que participaban.

\section{DE CÓMO EL TEATRO SE VOLVIÓ POPULAR}

El teatro popular de género chico mexicano no empezó con la Revolución Mexicana, su origen es el desenlace de una larga evolución teatral que se remonta a periodos anteriores. El teatro en el país ha tenido gran importancia desde la Colonia, época en la que se concebía como medio para difundir la cultura en el pueblo, principalmente en el siglo de las luces. "El hecho de que contara con una 
larga tradición en la Nueva España y de que el gusto por él estuviera fuertemente arraigado en las clases bajas, lo convertía en el espectáculo más idóneo para difundir los sentimientos, actitudes, valores e ideas de la llustración entre la población de la ciudad de México". ${ }^{27}$

La manera de entretenerse de la población fue vista de diferentes maneras en cada periodo histórico, el teatro se vio con buenos ojos durante el siglo XIX, ya que se suponía era una "buena escuela de costumbres", en la cual el bien siempre triunfaba y el mal se castigaba. ${ }^{128}$ Además de ser una expresión artística, el teatro sirvió para difundir un pensamiento social y político en la población. De la misma manera lo hicieron los primeros gobiernos independientes de México "[...] usaron al mismo teatro, y probablemente a los mismos actores de los que se habían valido los gobiernos virreinales para legitimarse, para difundir su ideario político". ${ }^{129}$ Por lo que el teatro siguió usándose para conveniencia del Estado e inculcarle al pueblo los valores morales y políticos de la clase dirigente.

Conforme avanzó el siglo XIX, el teatro mexicano se fue consolidando de manera independiente, para 1842 los actores ya no se importaban, se formaban en el propio país, aparecieron publicaciones de teatro y se construyeron grandes recintos en las principales ciudades del país, mientras que en la ciudad de México se incrementaron de manera considerable. ${ }^{130}$ Para entonces el teatro se consideraba un elemento que ejemplificaba el avance social y cultural de la nación.

Durante el último cuarto del siglo XIX se aprecian dos tendencias teatrales en la ciudad de México. Por un lado, se encuentra el espectáculo de la cultura dominante al cual pertenecía el "teatro culto", de corte europeo dirigido a las clases acomodadas de la sociedad. Por el otro, se encuentra una cultura popular en la que se desarrollaban representaciones escénicas dirigidas a la clase

\footnotetext{
127 Juan Pedro Viqueira Albán, op. cit., pág. 53.

${ }^{128}$ Anna Staples, "El siglo XIX", en Pablo González Escalante et al, Historia mínima de la vida cotidiana en México, México, El Colegio de México, 2010, pág. 159.

129 Juan Pedro Viqueira Albán, op. cit., pág. 121.

${ }^{130}$ Ana Luengo Sabine Schlickers, "'A tu patria mueves guerra...' Dramas mexicanos de la independencia" en Gustavo Leyva et al. (coordinadores), Independencia y Revolución: pasado, presente y futuro, UAM-FCE, México, 2010, pág. 315.
} 
trabajadora. ${ }^{131}$ Dentro del teatro "culto" se escenificaban las obras más exitosas de Europa, traídas al país por compañías, empresas y artistas de ese continente, representadas primordialmente en teatros como el Principal, Arbeu, Hidalgo y Nacional. Mientras que el teatro popular no contaba del todo con tendencias europeas, sino que estaba influido por las diversiones tradicionales como los títeres y el circo. "El teatro popular mexicano durante el último cuarto del siglo XIX desarrolló nuevas formas que si bien utilizaba convenciones y obras del teatro "culto", las transformaba, adaptándolas a los gustos y necesidades de los sectores populares. ${ }^{132}$ En aquel momento existían dos tipos de teatro popular: uno de temas obreros y el otro frívolo.

El teatro obrero formó parte de las actividades que realizaban las asociaciones mutualistas desde la década de 1870. Se fomentaba la acción política de los sectores populares, en su gran mayoría analfabeta, mediante este instrumento de comunicación masiva. ${ }^{133} \mathrm{~A}$ partir de las huelgas que acontecieron entre 1865 y 1880 el teatro fue utilizado como medio de difusión política y movilización, por lo que se en "los teatrillos de barrio como el Nuevo México, La Democracia y el Guerrero estrenaron obras a precios populares que, si bien en su mayoría eran de autores nacionales, algunas eran de extranjeros que difundían en México los valores e ideologías de los movimientos obreros de Europa". ${ }^{134}$ Asimismo se organizaban reuniones sociales en los teatros donde se daban discursos, declamaban poesía y tocaban música. El teatro obrero a partir de 1880 se fue disolviendo junto con la pérdida de fuerza de las asociaciones mutualistas que se transformaron en sociedades beneficiadas por el régimen porfirista. ${ }^{135}$

El otro tipo de teatro popular fue el frívolo o sicalíptico, con tendencias más sensuales y eróticas. Se trató con cierta tolerancia por las autoridades, aunque fue condenado por los moralistas e intelectuales y menospreciado por los críticos de teatro y la prensa, las obras de este género constituyeron la forma más vital y popular del naciente género chico mexicano. El régimen tuvo una actitud bastante

\footnotetext{
${ }^{131}$ Susan E. Bryan, “Teatro popular y sociedad durante el Porfiriato”, op. cit., pág. 131.

132 Ibidem, pág. 134.

${ }^{133}$ Ibidem, pág. 135 y 136

134 Ibidem, pág. 135.

135 Ibidem, pág. 139.
} 
benéfica hacía este género, mientras toleraba la "inmoralidad" en el teatro, no permitía la menor crítica política.

Ahora bien, a la par que se surgían estos géneros teatrales, también se desarrollaba una nueva manera de ofrecer el teatro. En España desde 1869 se vendía el teatro por horas, forma que se adoptó en México a partir de 1880, lo cual fue muy aceptado por el público. Esta forma de representación fue implementada en los grandes teatros de la ciudad de México; "a fines de 1902, había en la capital cinco teatros que representaban zarzuelas de género chico: el Principal, el Riva Palacio, el María Guerrero, el Apolo y el Guillermo Prieto" ${ }^{136}$, hecho que no fue del gusto de las clases medias y altas de la sociedad ya que significaba la mezcla con el público popular. Sin embargo, para las clases bajas significaba un símbolo de status social ya que podían disfrutar de estos teatros a un costo accesible. De esta manera se cambió el ambiente social dentro de los teatros porque las clases populares pudieron mezclarse con la elite y disfrutar las mismas obras.

Al adaptarse este modelo mercantil se descendieron considerablemente los precios de los boletos, abriéndose la oportunidad para que las clases bajas, generalmente impedidas por razones económicas para acceder a los teatros de la ciudad, adoptaran al teatro como forma de entretenimiento. Desde la introducción de la tanda, los teatros principales se habían vuelto accesibles al bolsillo de los obreros, de tal modo, que costaba lo mismo la entrada a un jacalón de barrio que a una función en un foro establecido y de renombre.

Se puede decir que la tanda fue el reducto por medio del cual el teatro "culto" se volvió "popular", y en buena medida se debió gracias a los empresarios que vieron más rentable reducir sus precios y atraer mayor público. "En el clásico sistema de vender el teatro por funciones, que duraban entre cinco y seis horas, los boletos se limitaban a galería. Con la tanda por una hora de espectáculo, había sólo dos tarifas: de medio real y de un real, precios iguales a los que se acostumbraba cobrar en los jacalones o en los teatrillos de barrio". ${ }^{137}$ De esta manera se rompió el paradigma la vida teatral de la ciudad de México, lo que

\footnotetext{
${ }^{136}$ Ibidem, pág. 147.

137 Ibidem, pág. 142.
} 
acarreó la transformación de la vida cotidiana y a la modificación de los contenidos y la estructura de las obras.

Manuel Gutiérrez Nájera describe al público popular en una obra de la siguiente forma:

El público gesticula y patalea como en los buenos tiempos de los jacalones, y los chistes obscenos son recibidos con groseras risotadas. Aquel no es el público de la comedia ni de la zarzuela. Es un público especial, muy parecido al que suele verse en el jardín del Zócalo en los días de fiesta nacional. El público ríe de todo estrepitosamente con carcajadas ordinarias de hombres que sólo asisten al teatro cuando se paga un real. El sombrero ancho extiende su enorme círculo junto a la chistera. La chaqueta codea con la levita [...] entran a él [palco] haciendo ruido con las sillas, toman actitudes desvergonzadas que ellos juzgan de buen tono y permanecen durante el espectáculo con el sombrero puesto. ${ }^{138}$

El comentario acentúa las diferencias de la forma de vestir y el comportamiento que distinguía a las clases medias y altas que eran parte de la clientela predominante y tradicional de los grandes teatros, con la del nuevo público popular. La introducción de la tanda en 1880 da cuenta de una clase dominante que se encuentra imposibilitada para mantener la exclusividad de su vida cultural.

La élite sentía sus espacios privilegiados invadidos gracias a la implementación de la tanda ya que los hábitos sociales de las clases bajas no coincidían con los suyos. Sin embargo para el pueblo, este acceso al teatro significó no sólo una diversión al alcance de su bolsillo, sino que era un medio para subir de status social. La tanda vino a romper su barrera de accesibilidad hacia una mejor posición social vista desde la manera de entretenerse.

Dentro de la lucha cotidiana por ascender la escala social el pelado podía comprar, con su boleto de medio real, no sólo una distracción importante, sino que adquiría el derecho a cruzar el umbral de un nuevo espacio-cultural al cual antes le estaba vetada la entrada. Sin embargo, el nuevo público no se conformaba a los patrones de comportamiento establecidos, ni buscaba una nueva forma de refinamiento cultural; en franco desafío a las establecidas reglas sociales de la cultura dominante, se imponía con los propios modales de

${ }^{138}$ Manuel Gutiérrez Nájera, "Las tandas del principal”, en Obras 111, Crónicas y artículos sobre teatro-I (1876-1880), UNAM, México, 1974, págs. 302-305. 
su medio, expresándose con los gritos, risotadas y majaderías tan características de los jacalones. $^{139}$

De esta manera las clases bajas lograron trasgredir los límites de esparcimiento de las élites, sin embargo no les interesaba refinar su comportamiento, se podría decir que incluso ellos querían imponer su propia conducta en los espacios hasta entonces conservadores.

Mientras tanto los empresarios de teatro seguían aplicando medidas para obtener mayores ganancias, como la de usar el telón con anuncios e imprimir publicidad comercial en los programas del teatro. ${ }^{140}$ Lo cual no resultaba agradable para los asistentes, sin embargo también era una manera de acaparar clientes que no acostumbraban leer el periódico y leer los anuncios.

En la primera década del siglo Xx, otro de los géneros teatrales más comunes fue el costumbrista, que buscaba una exaltación de los valores nacionales. Las obras que se escribían, si bien seguían la estructura de la zarzuela española, escenificaban paisajes y trajes regionales, tipos populares y problemas sociales nacionales. Los actores representaban a personajes tradicionales como la china poblana, el aguador, el charro, el indito o el lépero, abarcando a personajes tanto del ámbito rural como urbano. "Los tipos urbanos comprendían a los léperos, las sirvientas, al obrero fabril [...] contrastando con los campesinos, los tipos populares de la ciudad son listos, mañosos y abusivos". ${ }^{141}$ Mientras que los personajes del campo caían en el concepto de "pobres pero honrados", lo cual subraya claramente los pensamientos conservadores de la época aún porfiriana.

Los autores de teatro costumbrista escribieron obras con tintes folclóricos, "dando como resultado que los escenarios se comenzaran a llenar de ollas, sarapes, sombreros charros, bailarinas vestidas a la usanza de chinas poblanas, cantores bravíos y muchos otros elementos que se querían mostrar como parte de

\footnotetext{
${ }^{139}$ Susan E. Bryan, op. cit., pág. 165.

140 Ibidem, pág. 145.

141 Ibidem, pág. 153.
} 
lo mexicano", ${ }^{142}$ de esta forma se llegó a retratar a la sociedad de una manera pintoresca, sin embargo las obras carecía de cierto valor ideológico. Los autores de este tipo de obras en su mayoría eran periodistas pertenecientes a la cultura dominante, por lo que carecían de la posibilidad de realizar una crítica política directa. ${ }^{143}$

Al finalizar la primera década del siglo XX, junto con el inicio del movimiento armado, surgió otro género teatral gracias al rompimiento del control del régimen porfirista: el teatro político. Entonces el público adquirió el gusto por obras con temas políticos. Asimismo, a partir de 1909 el género mexicano se pudo consolidar, en cierta parte debido a que "la Sociedad de Autores Españoles se negó a proporcionar obras a los empresarios mexicanos", ${ }^{144}$ lo cual impulsó a que los autores mexicanos escribieran obras propias, y muchos lo hacían sobre los acontecimientos que se daban en el país.

El género político estuvo inmerso dentro de lo que se considera teatro de género chico, que tuvo una importante evolución debido a las circunstancias políticas y sociales particulares del país, lo que desembocó en el establecimiento de un género nacional muy diferente a los géneros importados de Europa: el teatro de revista mexicano.

Lo que dio en llamarse género chico, más que una estructura dramática, fue un tono que alentó un dinamismo transgresor, degenerador de las formas y convenciones asimiladas de la cultura identificada con las formas de dominio y control ideológico [...] El surgimiento del llamado género chico, supuso una invasión. Una especie de motín popular, una toma de la Bastilla teatral. Un asalto a los coliseos y casa de comedias, una sublevación de la zarzuela. En consecuencia, otro teatro, otros autores, otros escenarios, un nuevo tipo de actores y especialidades actorales, otros personajes, casi siempre típicos, en los mejores casos arquetípicos, pero sobre todo, un nuevo público y una nueva relación entre el teatro y la sociedad. ${ }^{145}$

\footnotetext{
${ }^{142}$ Carlos Pérez Bazán, "La identidad nacional en el teatro popular durante la primera década del siglo xx”, en Raúl Béjar y Silvano Héctor Rosales (coordinadores) La identidad nacional mexicana en las expresiones artísticas. Estudios históricos y contemporáneos, UNAM-Plaza y Valdés, México, 2008, pág. 53.

${ }^{143}$ Susan E. Bryan, op. cit., pág. 152.

${ }^{144}$ Aurelio De los Reyes, Cine y sociedad en México 1896-1930. Volumen I Vivir de sueños, op. cit., pág. 224.

${ }^{145}$ Luis de Tavira, "Prólogo", en Armando de Maria y Campos, Teatro de género chico, op. cit., pág. XIII.
} 
La forma que adquirió la representación del género chico fue mediante el teatro de revista, que se podía considerar como "una ojeada satírica a los acontecimientos de la actualidad, especie de noticiero teatral que a partir de 1911 adquirió un matiz eminentemente político [...] Quizá el nombre derive de la prensa, de las revistas periódicas que informaban al público sobre la actualidad [...] Al igual que la zarzuela, la revista fue musicalizada y los diálogos cantados". ${ }^{146}$ En el periodo de "1909 a 1917 aproximadamente las obras tienen como característica el chiste político, la sátira descarnada y la ridiculización de todo aquello que tuviera alguna liga con el antiguo régimen". ${ }^{147}$ Durante estos años salió toda la represión contenida en la etapa porfirista y fue expresado abiertamente en los teatros.

La revista tenía una estructura muy particular, consistía en una forma libre de contar un suceso, conocido previamente por el espectador, mediante la parodia a personajes de la vida real, principalmente políticos, y se intercalaba con números musicales y bailes, todo con un ambiente picaresco. "Tenía una trama central que podía tardar toda la obra en desenlazarse, y sobre su desarrollo se hilvanaban los pretextos pertinentes para introducir los episodios más disparatados o arbitrariamente asociados entre sí". ${ }^{148}$

Pablo Dueñas y Jesús Flores y Escalante se refieren al teatro de revista como:

El término revista se refiere al género cuya principal particularidad consistió en llevar a escena una serie de dramatizaciones basadas en hechos reales, actuales o pretéritos, de manera satírica, por lo general cómica, y en forma de parodia. Curiosamente no existe un patrón determinado que ejemplifique la estructura básica de la revista, ya que los autores que la cultivaron le dieron sin distinción rasgos de la zarzuela, sainete o astracanada, subgéneros todos ellos emparentados entre sí. ${ }^{149}$

Las revistas se representaban en teatros establecidos o carpas; sus autores fueron en su mayoría periodistas de profesión, o personas relacionadas con

\footnotetext{
${ }^{146}$ Aurelio de los Reyes, Cine y sociedad en México 1896-1930. Volumen I Vivir de sueños, op. cit., pág. 219.

${ }^{147}$ Carlos Pérez Bazán, op. cit., pág. 47.

148 Eduardo Contreras Soto, "A caballo entre mundos y estilos. Las dramaturgias mexicanas y sus vidas escénicas en los inicios del siglo xx", en David Olguín (coordinador), Un siglo de teatro en México, CONACULTAFCE, México, 2011, pág. 23.

${ }^{149}$ Pablo Dueñas y Jesús Flores y Escalante, op. cit., pág. 11.
} 
políticos a través de puestos, cargos o empleos. "En los casos de periodos electorales, han sido partidarios o enemigos de los candidatos a la Presidencia de la República, antes o después de ser tomada, sujetándose el mayor porcentaje de asuntos para escenas, situaciones, cantables y chistes en general". 150 De tal manera que los escritores tuvieron la libertad de tomar partido en las representaciones teatrales según sus ideas, tendencias y conveniencias políticas.

La función social de la revista cumplió un papel crítico al estilo mexicano: reírse de la tragedia. ${ }^{151}$ Tuvo la misma función que el periódico y fue apreciada por la población analfabeta, "quienes no estaban capacitados para leer un periódico, les bastaba sólo con acudir al teatro más cercano para enterarse de la noticia más reciente". ${ }^{152}$ Asimismo la mayoría de los escritores de teatro de revista eran periodistas, y lo que no podían expresar libremente en los diarios lo manifestaban mediante las obras.

La revista política se convirtió en un éxito, se escribían muchas a la semana y se representaban en la mayoría de los teatros y carpas, donde duraban pocos días y se remplazaban por otras nuevas. "El grado de interés está en relación directa con la contigüidad. $Y$ en el teatro es inmediato el "interés local". En una obra mexicana un chiste de actualidad puede atraer más público que cualquier otra obra extranjera toda ella graciosa". ${ }^{153}$ Los autores se mantenían al pendiente de los acontecimientos políticos para trasladar las noticias al lenguaje teatral.

Las tandas revisteriles se presentaban principalmente en dos teatros, el Lírico y el Principal, a este último se le llegó a conocer como "la catedral de la tanda", hasta que se destruyó debido a un incendio en 1931. Una de las más grandes compañías de teatro de revista fue la de Roberto Soto, conocida como Compañía Mexicana de Revistas, en 1938 dos de sus revistas, México a través de los siglos y Rayando el sol, se llegaron a presentar en el Palacio de Bellas Artes. Otro de los autores más importantes del teatro de revista fue Pablo Prida, quien también fungió como empresario.

\footnotetext{
${ }^{150}$ Armando de Maria y Campos, El teatro de género chico, op. cit., pág. 6.

151 Josefina Estrada, op. cit., pág. 39.

${ }^{152}$ Pablo Dueñas y Jesús Flores y Escalante, op. cit., pág. 25.

${ }^{153}$ El Universal llustrado, 22 de noviembre de 1928, pág. 28.
} 
En otro apartado se abordará de manera más amplia el contenido de las obras y el impacto político que tuvieron con sus correspondientes consecuencias. Por el momento trataremos de entender cómo se fue desenvolviendo el género mismo y los espacios donde se desarrolló. El gusto por el género político provocó que los empresarios teatrales abrieran nuevos locales y establecieran carpas por los barrios de la ciudad, que se instalaban de manera intermitente en las plazas públicas.

Es preciso aclarar que no es lo mismo teatro de carpa que teatro de revista, sin embargo guardan cierta relación. El teatro de carpa se refiere al espacio donde se lleva a cabo el espectáculo, en este caso se refiere a carpas establecidas momentáneamente en plazas públicas o terrenos baldíos. $Y$ el teatro de revista se refiere a un género teatral cómico musical descendiente de la zarzuela y la opereta. Para entonces el teatro de revista se podía llevar a cabo tanto en los grandes teatros como en cualquier tipo de carpa. Las carpas le aportan al teatro de revista un ambiente más popular.

El espectáculo de carpas no puede ser comparado con los patrones de belleza del teatro y arte eurocentrista, ya que no admiten fácilmente otro tipo de estética, sin embargo es precisamente ese otro tipo de estética lo que proponen las expresiones populares que no se amoldan al paradigma de arte clásico. ${ }^{154}$ Lo que propone la carpa es otra manera de expresar el arte desde abajo, su objetivo no es satisfacer los gustos más refinados, sino plantear una forma diferente de expresión.

El teatro de género político fue muy popular en la primera mitad del siglo XX, la población gustaba de los temas y los autores no se daban abasto escribiendo obras, sin embargo hubo un paréntesis ya que cuando se pensaba que lo francés había dejado de influir en el país, en febrero de 1925 la "compañía de revistas francesas Ba-ta-clán" dirigida por Madame Berthe Rasimi llegó a México debutando en el teatro Esperanza Iris, presentó un espectáculo de revista tal y como lo hacían los franceses: con juegos de luces, música alegre y mujeres sin

${ }^{154}$ Socorro Merlín, Vida y milagros de las carpas, op. cit., pág. 89. 
mallas desfilando por la pasarela para el regocijo de los espectadores. ${ }^{155} \mathrm{La}$ población gustó tanto de esta atracción, que se detuvo por un momento la representación de revistas políticas hasta que la fiebre bataclanesca pasó de moda.

Con la crisis de 1929 los grandes teatros comenzaron a cerrar o a convertirse en cines debido a los altos costos por mantenerlos, por lo que muchos empresarios se inclinaron al espectáculo carpero, por ser éste más rentable y con menos inversión.

A partir de 1931 se introduce el sketch en teatros y carpas, "fue uno de los recursos que cambió la estructura espectacular carpera, al no depender ya ésta de un libreto escrito para la realización de un espectáculo, sino de aquellos como módulo principal de canciones y bailes". ${ }^{156}$ Este recurso fue de gran ayuda para los artistas ya que podían en varias carpas el mismo día presentando el mismo sketch, como fue el caso del famoso Conde Boby que se daba el lujo de actuar en tres carpas a la vez. Por ejemplo, en Santa María la Redonda, en el jardín de Los Ángeles, así como en el jardín del Carmen. ${ }^{157}$ La revista finalmente cambió de manera radical en 1944 en su forma de organizar el espectáculo. El Teatro Follies venía restándole importancia al libreto de las revistas, contratando de preferencia números de variedad, como cancioneros, actos de circo, duetos y tríos, monólogos, entre otras diversiones, que se insertaban en los cuadros de la revista. Ya Cantinflas había introducido la costumbre del diálogo entre el actor cómico y su "patiño". ${ }^{158}$ Así el sketch llegó a ser el número más versátil de las atracciones dentro de las carpas y se dejaron a lado los asuntos políticos. Ya no pretendía plasmar una labor social o de denuncia como se hizo en otro tiempo. Los empresarios adecuaron el espectáculo según la demanda teatral, lo que quiere decir que el público dejó de gustar de los temas políticos y prefería divertirse con espectáculos con otro sentido, además de que los empresarios procuraban llevar

\footnotetext{
${ }^{155}$ Pablo Dueñas, op. cit., pág. 162.

${ }^{156}$ Socorro Merlín, Vida y milagros de las carpas, op. cit., pág. 26.

157 Pedro Granados, op. cit., pág. 59.

${ }^{158}$ Armando de Maria y Campos, Teatro de género chico, op. cit., pág. 422.
} 
una buena relación con el Estado a fin de obtener concesiones en el pago de impuestos y en los permisos para representar este tipo de espectáculos.

En cierta medida muchos autores y actores se volvieron apáticos y se perdió la capacidad de improvisación, los libretos fueron cada vez más simbólicos con el auge del sketch, que no tenía mayor complicación. Si embargo hubo escritores revisteriles como Pablo Prida, Rodolfo Sandoval y Guz Águila, que trataron de mantener al género chico dentro de los márgenes de calidad, ${ }^{159}$ misión que no fue del todo exitosa.

Asimismo la revista poco a poco se fue despolitizando para convertirse en musical, aunado a la fama de Agustín Lara, cuyas composiciones encajaban en las nuevas exigencias teatrales, lo cual Roberto Soto, entre otro empresarios retomaron para incorporarlo a sus obras, ${ }^{160}$ formando así revistas de corte más ligero.

El teatro claramente se despolitiza y va adquiriendo otro tipo de género basado en los sentimientos, como se verá más adelante, "la revista viaja hacia la intimidad, la música abandona las causas colectivas y se instala plenamente en el corazón, para cuyas lágrimas siempre habrá el disco adecuado con la adecuada tersa voz [...] Las horas públicas de la revista le dan la espalda a la política y a la historia para hacer crónica de las vicisitudes del corazón enamorado". ${ }^{161}$ La revista romántica y el teatro de variedades le dan el tiro de gracia a la revista política, asimismo el público se vuelve más sumiso, mientras la industria del espectáculo se empieza a institucionalizar más tarde por medio del cine, el radio y la televisión.

\section{AL CUIDADO DE LA MORAL Y LA SALUBRIDAD}

Desde finales del siglo XIX, la ciudad cambió radicalmente. Los parámetros de higiene vinculados a nuevos descubrimientos científicos y al saneamiento de los barrios se convirtieron en criterios dominantes que proyectaron la modernización urbana. "Los ideales modernizadores de las élites porfirianas se enfrentaron con un proceso de densificación poblacional, lo cual generó múltiples discusiones

\footnotetext{
${ }^{159}$ Pablo Dueñas y Jesús Flores y Escalante, op. cit., pág. 35.

160 Ibidem, pág. 31.

${ }^{161}$ Alfonso Morales, op. cit., pág. 112.
} 
sobre la necesidad de mejorar las condiciones de salubridad y controlar la moralidad". ${ }^{162}$ De acuerdo con lo especificado en el artículo 14 del Código Sanitario y al artículo primero del Reglamento de Teatros vigente a principios de siglo XX, antes de expedir una licencia para abrir al público un centro de diversión se solicita al Consejo de Salubridad el informe correspondiente en los puntos de higiene y seguridad del público. Una vez dado el permiso y abierto el mencionado centro, se establece la vigilancia adecuada para que las disposiciones acerca de la higiene y seguridad del público se cumplan. ${ }^{163}$

La mayoría de las diversiones para las clases populares no tenían lugares establecidos, se desarrollaban por lo general en las plazuelas o vías públicas. Múltiples empresarios de teatros, circos o cinematógrafos solicitaban permiso para establecer sus carpas de plazuela en plazuela por la ciudad. Para ser concedidos se requería, por una parte, que el lugar contara con las medidas sanitarias adecuadas y, por otra, que el espectáculo no se excediera los límites de la moralidad permitida en aquellos años.

Para realizar los diferentes espectáculos se necesitaba el consentimiento del Ayuntamiento, como es el caso del señor José Balderas, quién en 1901 solicita permiso para dar funciones con acróbatas en una casa de la colonia Morelos, el cual se le concede al pagar la cuota que señala la ley. ${ }^{164}$ Lo mismo sucedía para quienes querían dar funciones de títeres, figuras en movimiento, exhibición de figuras de cera, mesas de tiro al blanco, entre otras diversiones. No se podían dar espectáculos en la vía pública ni en lugares establecidos sin el consentimiento del Ayuntamiento.

En 1920 el jefe de la sección de diversiones públicas le envía un escrito al presidente municipal, donde manifiesta que:

Siendo la actual época del año propicia al desarrollo de enfermedades que con facilidad pueden convertirse en epidémicas, y siendo los centros de espectáculos por la natural aglomeración del público, sitios de fácil contagio, me permito solicitar de esa superioridad que, en previsión de las aludidas epidemias se sirva acordar una disposición en el sentido

\footnotetext{
${ }^{162}$ Mario Barbosa Cruz, El trabajo en las calles, op. cit., pág. 41.

${ }^{163}$ AHDF, Fondo: Ayuntamiento; Sección: Diversiones públicas; vol. 807; exp. 1329.

${ }^{164}$ AHDF, Fondo: Ayuntamiento; Sección: Diversiones Públicas; vol. 806; exp. 1095.
} 
siguiente: Desde esta fecha y hasta nuevo aviso, todos los empresarios o encargados de teatros y cines quedan obligados a desinfectar sus respectivos locales, una hora antes de comenzar los espectáculos, usando al efecto y con la necesaria abundancia soluciones de creolina u otro desinfectante parecido. ${ }^{165}$

Los empresarios de teatros eran obligados a mantenerse al margen de las medidas sanitarias establecidas por el Ayuntamiento, de lo contrario sus espacios de entretenimiento resultaban sancionados o de plano clausurados.

Muchas de las actividades realizadas por las clases populares eran criticadas por las élites y sancionadas por las autoridades. En una carpa para dar funciones de títeres, instalada en la plazuela de la Alhóndiga, según las autoridades de salubridad, "el público que concurre a ellas, amparado por la oscuridad, hace sus necesidades en la vía pública, en la proximidad de la carpa y en las banquetas". ${ }^{166}$ El comportamiento de la clase popular fue duramente criticado, tanto por el gobierno como por las élites, por lo que siempre se procuró remediar.

En 1902, el empresario, Roberto Bonilla, solicitó permiso para trasladar su circo de la Ribera de San Cosme a la calle de Zarco, por lo que la Comisión, al realizar una inspección en el lugar solicitado, consideró que no reunía las medidas sanitarias adecuadas ya que "en el terreno que se trata hay una gran cantidad de basuras y estiércol, cuyas miasmas, afectando la salubridad pública serían nocivos a las personas que concurrieran al repetido circo". ${ }^{167}$ Por lo que la Comisión de Diversiones no accede a la petición del empresario para trasladar su circo. Lo mismo pasó con el empresario José Juárez, quien al solicitar permiso para establecer un circo en el puente de San Antonio Abad, le fue negado debido a que el lugar requerido estaba destinado a la limpia de viseras de animales que se sacrificaban en el rastro de la ciudad. ${ }^{168}$ Esto muestra cómo la ciudad carecía de espacios dignos para las diversiones públicas dirigidas a los sectores populares.

\footnotetext{
165 AHDF, Fondo: Ayuntamiento; Sección: Diversiones públicas; vol. 810; exp. 1581.

${ }^{166}$ Vecinos de la plazuela de la Alhóndiga al Departamento de Salubridad, 29 de octubre de 1918, AHDF, PS, vol. 3672, exp. 303. Citado por Mario Barbosa Cruz, El trabajo en las calles, op. cit., pág. 204.

${ }^{167}$ AHDF, Fondo: Ayuntamiento; Sección: Diversiones públicas; vol. 806; exp. 1092.

${ }^{168}$ AHDF, Fondo: Ayuntamiento; Sección: Diversiones públicas; vol. 806; exp. 1194.
} 
También se criticaba el comportamiento dentro de los espacios de entretenimiento, como permanecer con el sombrero puesto, que el público acostumbre fumar, o el no haber suficientes escupideras en los teatros, medidas que van de la mano la introducción del género chico en los recintos. El Ayuntamiento en 1902, mediante un acuerdo, indica a las empresas teatrales la obligación que tienen de vigilar que no se fume en los teatros:

Con el funesto "género chico", el fumador inculto ha llegado a hacerse incorregible [...] pues hoy se permite el lujo de ostentar enormes puros, desde que penetra al teatro, hasta que sale de él, sin consideración alguna a las señoras y olvidando por completo no sólo las leyes municipales sino las condiciones inolvidables de la educación.

Sin llegar a la hipérbole puede asegurarse que en los teatros de las tandas, ha desaparecido por completo todo escrúpulo por parte de los fumadores, pues no hay un solo sitio en que dejen de hacer gala del vicio.

Establecida, pues, como precepto reglamentario la prohibición de fumar en los teatros, corresponde a las empresas vigilar estrictamente el cumplimiento de tal disposición ocurriendo a la autoridad municipal o a la policía en todos los casos que fuere necesario proceder en determinada forma con algún infractor.

Sala de comisiones. ${ }^{169}$

A las élites "les parecía tan "obsceno y repugnante" cómo el público que se carcajeaba sin pudor y permanecía con el sombrero puesto durante toda la función [...] motivaban el "asombro y repugnancia" de los críticos, que vislumbraban la degeneración del teatro en manos de un "público inmoral" que buscaba "diversión indecente". ${ }^{170}$ Esto pasó en mayor medida cuando se implementó el teatro por tandas y las clases populares tuvieron acceso a los grandes recintos, como lo vimos en un apartado anterior.

Las tandas se anunciaron siempre como entretenimiento familiar, por lo menos en las primeras tandas de la tarde y de la noche, después de esa hora nadie se hacía responsable de tal afirmación. "La última tanda estaba destinada a un público mayoritario de hombres, pocas mujeres, las arriesgadas para trasnochar o prostitutas y a los artistas o a algunos esnob que gustaban por

\footnotetext{
${ }^{169}$ AHDF, Fondo: Ayuntamiento; Sección: Diversiones públicas; vol. 806; exp: 1163.

170 María Dolores Lorenzo Río, op. cit., pág. 246.
} 
circular esos lugares". ${ }^{171}$ En 1912 el Ayuntamiento establece: "Prohíbase la representación de zarzuelas inmorales que son un colegio de corrupción para las familias que ignorantes del argumento de las representaciones, concurren a divertirse en unión de niños que fácilmente se pervierten o hacen nacer en ellos la malicia con todas sus consecuencias". ${ }^{172} \mathrm{Y}$ aclaran que en caso de que no se pueda prohibir, por lo menos se ponga en los programas que el espectáculo será para hombres solos y que se vigilen las entradas para evitar el acceso a menores de edad.

En 1904, debido al cambio programación en diversos teatros, la Comisión de Diversiones designa concejales para presidir las obras y vigilar que no se presenten alteraciones. Inicialmente estos servidores fueron elegidos para vigilar las funciones de los teatros: Arbeu, Renacimiento, Principal, Hidalgo, Riva Palacio, Frontón y el Circo Orrín, y en años posteriores encomiendan a concejales a presidir otro tipo de diversiones como las corridas de toros, cinematógrafos y demás teatros. Con estas medidas se comienzan a sancionar a los empresarios de los espectáculos, tanto por alteraciones en la programación, como por otras normas, como es el caso de un concejal que acude al Circo Orrín y reporta que en un acto donde participan leones no hay medidas de seguridad suficientes para salvaguardar la integridad del público, ${ }^{173}$ por lo que la Sala de Comisiones indica a el empresario del circo que adecúe su espectáculo a modo que los asistentes no corran peligro alguno.

Los concejales denuncian todo tipo de irregularidades y las multas impuestas a los centros de espectáculos comienzan a crecer. En muchos casos se cambiaban los actores anunciados argumentando que los establecidos en el programa se encontraban enfermos, por lo que el Ayuntamiento en estos casos pedía un justificante médico para comprobar que efectivamente los actores no se encontraban en las condiciones saludables para desempeñar su trabajo.

\footnotetext{
${ }^{171}$ Socorro Merlín, Vida y milagro en las carpas, op. cit., pág. 36.

${ }^{172}$ AHDF, Fondo: Ayuntamiento; Sección: Diversiones públicas; vol. 807; exp. 1322.

${ }^{173}$ AHDF, Fondo: Ayuntamiento; Sección: Diversiones públicas; vol. 807; exp. 1281.
} 
En cierta medida, el Ayuntamiento trataba de proteger la moralidad de las familias, como es el caso de una zarzuela, en 1909, cuyo contenido no era apto para todo tipo de público, por lo que las autoridades dispusieron lo siguiente:

Prohíbase la representación de zarzuelas inmorales que son un colegio de corrupción para las familias que, ignorantes del argumento de las representaciones, concurren a divertirse en unión de niños que fácilmente se pervierten o hacen nacer en ellos la malicia con todas sus consecuencias.

En caso de no ser posible suprimir la representación de estas zarzuelas, que los empresarios hagan notar en los programas y avisos que se reparten al público, que serán para hombres solos y que se vigilen las puertas de entrada para que no sean admitidos menores de edad. ${ }^{174}$

Los "científicos" trataban de depurar el gusto de la población, según ellos el espectáculo de carpas hacía que la cultura del pueblo retrocediera. Por lo que se tuvo la idea de crear un teatro que llevara a los barrios de la ciudad "un espectáculo culto al que no asistieran por carencia de fondos o por la prostitución del gusto causada por el género chico". ${ }^{175}$ Una nota de El Imparcial apuntaba: "pongamos el arte dramático más a la mano del pueblo. Démosle, no artistas célebres, no estrellas del escenario, sino compañías modestas que le den a paladear un poco de arte". ${ }^{176}$ Asimismo la prensa "se quejaba de que el público no acudía a los grandes teatros, el Nacional o el Arbeu, a presenciar las obras de los clásicos, o de la ópera, ni siquiera las compañías de arte dramático francesas o italianas que nos visitaban". ${ }^{177}$ Pero el público quería reír, prefería asistir a las zarzuelas que al teatro culto. Sin embargo los intelectuales seguían afanándose en alejar al pueblo y a los autores del teatro popular y en 1906 Justo Sierra convocó a un concurso de dramas y comedias para autores nacionales, para que los escritores dejaran el género chico, y nombró a un jurado compuesto por

\footnotetext{
${ }^{174}$ AHDF, Fondo: Ayuntamiento; Sección: Diversiones públicas; vol. 807; exp. 1322.

${ }^{175}$ Luis Reyes de la Maza, 100 años de teatro en México, op. cit., pág. 142.

176 "El teatro popular", El Imparcial, martes 22 de abril de 1902, no. 2041.

${ }^{177}$ Aurelio de los Reyes, Cine y sociedad en México 1896-1930. Volumen I Vivir de sueños, op. cit., pág. 33.
} 
Virginia Fábregas, José María Vigil, Luis G. Urbina y el autor español Francisco Fuentes, quienes recibieron más de 60 obras. ${ }^{178}$

Es su afán de desprestigiar al género chico, el cronista Luis G. Urbina escribe en El mundo ilustrado en 1908:

La tanda es un divertimiento cómodo y barato. Nuestra pereza intelectual, nuestra flacidez moral, nos inclinan naturalmente del lado de un espectáculo frívolo y ligero, que no pide preparaciones previas, ni exige el ejercicio del pensamiento o del sentimiento, sino que, sacudiendo los instintos, excitando las maldades antropológicas, rascando e irritando las innatas perversidades, pone en los labios humanos una risa de fauno beodo, y quema un grano de tentación torpe en las almas amodorradas. ${ }^{179}$

De esta manera muchos cronistas y escritores criticaban al género chico, sin embargo el público gustaba seguía asistiendo, por lo que los intentos de alejarlo él resultaron vanos.

Durante el Porfiriato fue prioridad el control sanitario y moral más que el de libertad de expresión, ya que los autores tenían sobreentendido que atacar al régimen significaba atentar contra su propia integridad. Una vez derrotado el gobierno de Díaz los autores tuvieron oportunidad de escribir obras de carácter político, lo que no significa que no hubo cierto control por parte del Ayuntamiento, como se verá en el siguiente apartado.

\section{LA TOLERANCIA DE LA EXPRESIÓN POLÍTICA}

La tolerancia sobre críticas políticas dentro de los teatros fue muy cuidadosa durante el gobierno de Porfirio Díaz. No se permitía el menor tema que atacara al régimen. Si se quería hablar de política tenía que ser a favor del gobierno, resaltando positivamente las acciones del presidente. Incluso cuando en 1902 se formó la Sociedad de Autores Mexicanos, ${ }^{180}$ en la reunión de escritores teatrales no figuraban entre sus miembros personas sospechosas de pensamientos revolucionarios, todos eran ciudadanos de ideas políticas conservadoras.

\footnotetext{
${ }^{178}$ Luis Reyes de la Maza, Cien años de teatro en México, op. cit., pág. 151.

${ }^{179}$ Armando de Maria y Campos, Teatro de género chico, op. cit., pág. 39.

180 Ibidem, pág. 37.
} 
Una de las obras que enaltecía al gobierno porfirista poco antes de llegar a su fin fue A muerto rey, rey puesto de 1908, escrita por Alberto y Alejandro Michel y Adolfo Bernáldez, que trató de los acontecimientos más notables del régimen junto con adulaciones al presidente. Incluso los autores pertenecientes al gobierno escribían obras en contra de la oposición política que tenían, una de ellas fue Madero Chantecler, escrita en 1910 por el antimaderista José Juan Tablada, donde se ridiculizaba la figura de Madero. ${ }^{181}$

En 1907 se estrenó En la hacienda, zarzuela en la que se llevó por primera vez el tema de la precaria vida del peón de campo, de los abusos que los hacendados cometían con él y con sus mujeres, y de cómo el peón, rompiendo una tradición que se hacía intocable al amo, mata a éste para vengar su honra, revelándose contra en tradicional derecho de pernada. ${ }^{182}$ Incluso esta fue la primera pieza mexicana de género chico que se llevó a la pantalla en 1921. Mientras tanto los asuntos políticos ya se venían asomando desde obras como Sangre obrera (1906), cuyo tema era la huelga de Cananea, y Rebelión (1907) que tocó el de la explotación maya, sin embargo fueron censuradas. El autor de esta última, el periodista Lorenzo Rosado, fue obligado a salir del país. ${ }^{183}$

La revista México nuevo, se estrenó en 1909, de la autoría de Carlos M. Ortega y Carlos Fernández Benedicto. En uno de sus cuadros titulado El circo se hacía una parodia de Ramón Corral y el General Bernardo Reyes, candidatos a la vicepresidencia de la República. Antes de estrenarse, el empresario Francisco Briseño recibió un aviso del Gobierno del Distrito, el cual decía que si México Nuevo causaba algún escándalo, se cerraría el teatro y los autores irían a la cárcel. Debido a que la obra fue un éxito, los autores fueron encarcelados días después del estreno de la obra por órdenes del gobernador Ignacio Burgoa, con el pretexto de que ofendían al ejército nacional en un cuadro en el que aparecían los cadetes del Colegio Militar, unos como partidarios del clavel blanco y otros a favor

\footnotetext{
${ }^{181}$ Pablo Dueñas, op. cit., pág. 132.

${ }^{182}$ Armando de Maria y Campos, Teatro de género chico, op. cit., pág. 39.

${ }^{183}$ Susan E. Bryan, op. cit., pág. 160.
} 
del clavel rojo. ${ }^{184}$ Esta fue la primera revista política que adquirió su éxito gracias a la parodia de personajes públicos en el poder.

En 1910 el escritor Luis G. Andrade debutó en el teatro con una obra titulada Crudo invierno, en la que por un chiste que aludía al gobernador Guillermo de Landa y Escandón, pasó una noche en la cuarta comisaría. Andrade llamó al gobernante don Relleno de Lana y Algodón. ${ }^{185}$

Ya en 1911, cuando el régimen de Díaz había concluido, se escribió un mayor número de revistas políticas, ese año se estrenó Instrucción obligatoria, revista de liberales y provocadores temas políticos que tuvo mucho éxito. Posteriormente se estrenó la revista El país de la alegría, por aquello de que al fin había caído la dictadura porfirista. En el libreto de aquella revista aparecía el estribillo de una parodia de la Mamá Carlota imperialista, que cantaba Leopoldo El cuatezón Beristáin, y que decía:

\footnotetext{
Adiós a don Porfirio,

Adiós Ramón Corral.

Se fue ya Carmelita,

El pueblo va a mandar. ${ }^{186}$
}

Sin embargo la libertad de expresión no fue del todo solucionada con la caída del régimen porfirista. Dentro del gobierno de Madero se seguía manteniendo un control sobre el contenido de las obras representadas. En 1912 estrena El chanchullo, de Rodolfo Navarrete, y en un cuadro aparece un viejo fachoso de nombre Víctor con una botella de vino en la mano, personaje que evidentemente parodiaba a Victoriano Huerta haciendo mofa de su alcoholismo, razón por la que fueron a parar a la cárcel desde el empresario hasta el tramoyista de la obra. ${ }^{187}$

Ese mismo año Luis G. Andrade escribió El terrible Zapata, cuando la prensa capitalina pintaba al caudillo con tonos de pavor y escándalo. Se estrenó en el Teatro Lírico, y el título provocó que acudieran al teatro revolucionarios de todos

\footnotetext{
${ }^{184}$ Armando de Maria y Campos, Teatro de género chico, op. cit., pág. 56.

185 Ibidem, pág. 90.

186 Ibidem, pág. 82.

187 Ibidem, pág. 123.
} 
los calibres. Armando de Maria y Campos nos describe lo acontecido durante su representación:

Al advertirse en el teatro la presencia del temible cabecilla Emiliano Zapata, prolijo es decir el pánico que se apoderó de los artistas intérpretes de El terrible Zapata [...] No había concluido el primer cuadro de la revista, cuando una docena de pavorosos empistolados entró como tropel desbocado al foro, buscando al autor y al empresario [...] Y como Zapata sentenciara a muerte al empresario Arago si volvía a representarse esa obra, hubo de suspenderse, y yo tuve que marcharme a veranear a Veracruz durante varias semanas, con el derrame de bilis consiguiente. ${ }^{188}$

De esta manera se puede apreciar qué tanto impacto generaron las revistas políticas en los personajes involucrados, ya que en ellas se manifestaban imaginarios que se transmitían al público, por lo que los personajes aludidos, hayan sido del gobierno o revolucionarios, cuidaban que se imagen no fuera tomada para fines no deseados.

Además del Ayuntamiento y de los grupos revolucionarios, había grupos de élite que se manifestaban contra cierto tipo de representaciones teatrales que, según ellos, atentaban contra la moral de la época, como lo llega a testimoniar el siguiente documento:

\section{LA MORAL INSULTADA EN EL TEATRO HIDALGO}

Los subscritos, con diferentes credos políticos y religiosos: PROTESTAMOS ENERGIAMENTE contra las indecencias supinas que comienzan a exhibirse en el antiguo TEATRO HIDALGO de esta capital, lugar que siempre había inspirado confianza a toda esta culta y católica sociedad.

Mientras no se suprima esta cínica y sucia variedad del "PARÍS CORROMPIDO" nos abstendremos de concurrir con nuestras familias y amistades y tomaremos todos los resortes para que sea castigada esta Empresa que ofende y lastima a toda una sociedad que podría ayudarle, pero que por hoy, trata de explotar con tanta inmoralidad y escándalo, que repugnaría a los más prostituidos y aún por dentro de sus prostíbulos.

México, Enero 29 de $1912 .^{189}$

\footnotetext{
${ }^{188}$ Ibidem, pág. 100.

${ }^{189}$ AHDF, Fondo: Ayuntamiento; Sección: Diversiones públicas; vol. 807; exp. 1334. Énfasis en el original.
} 
El documento es firmado por veintiocho personas, sin embargo no aparece en el expediente muestras de que le dieran seguimiento a este asunto y se desconoce si se llegó a censurar dicha representación.

En febrero de 1913 aconteció la Decena Trágica, que dejó como consecuencia la muerte de Francisco I. Madero y desencadenó la toma presidencial de Victoriano Huerta; y para mayo de ese mismo año se puso en escena en el teatro Lírico la revista El país de la metralla, con autoría de José F. Elizondo y música de Rafael Gascón, la obra retrataba los sucesos de la Ciudadela además de ser explícitamente anticarrancista. El mismo Victoriano Huerta presenció la obra en el mes de junio, atendido personalmente por el propio Gazcón, ${ }^{190}$ y fue muy de su agrado, principalmente un cuadro donde se parodia a Carranza y Maytorena, tachados como vendepatrias. En el libreto Carranza aparece como Vespaciano, y Maytorena como Cantorena:

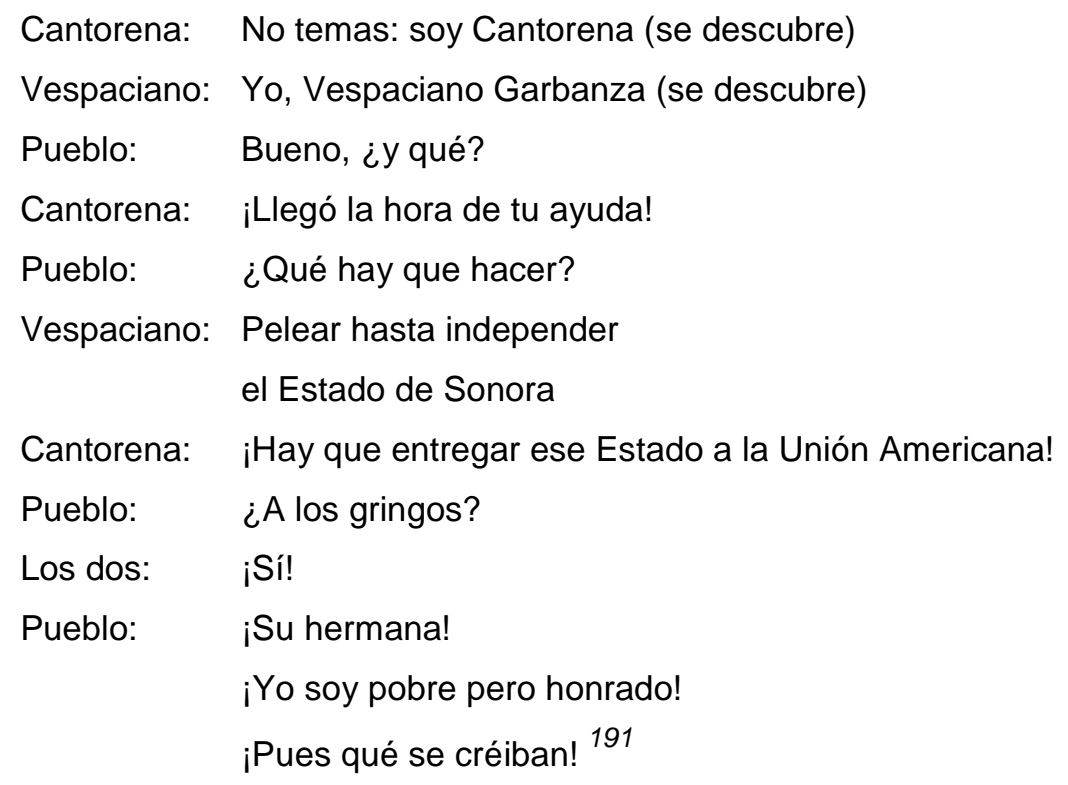

Elizondo criticó severamente a Carranza, sin embargo con la renuncia de Huerta, en junio de 1914, tanto Elizondo como Gazcón empezaron a ser perseguidos por sus críticas, "Carranza -o alguno de sus generales- les mandó un recado: "que más les vale pelarse, porque iban a ser ahorcados". Elizondo salió hacia Cuba, en

\footnotetext{
${ }^{190}$ Pablo Dueñas, op. cit., pág. 135.

191 AGN, Propiedad artística y literaria, vol. 258, exp. 8693.
} 
tanto que Gazcón se mantuvo oculto, no pudo soportar más las presiones y mentalmente trastornado falleció el 9 de mayo de 1915 a causa de una embolia cerebral". ${ }^{192}$ Ese fue el problema de autores que apoyaban a determinados personajes presentes en el poder y criticaban a otros que no se imaginaban que algún día podrían perseguirlos por sus anteriores ideas difundidas.

Lo mismo pasó con Leopoldo El cuatezón Beristáin, quien tuvo que huir a Cuba, ya que en un principio criticó de manera consistente al movimiento revolucionario de Madero, y después al movimiento constitucionalista, incluso fue protegido por el régimen de Huerta, ya que enaltecía su imagen, sin saber que posteriormente aquellos atrevimientos desencadenarían en el declive de su carrera. ${ }^{193}$ Tanto Elizondo como Beristáin permanecieron en el exilio hasta que el gobierno interino de Adolfo de la Huerta les permitió regresar al país.

Mientras tanto la ciudad fue ocupada por las tropas federales y los grupos revolucionarios, muchos soldados aprovecharon para entrar a los teatros a divertirse con las obras exhibidas, así como gustaban de ir a las cantinas y burdeles. Sin embargo fue entre 1914 y 1915 cuando los habitantes de la ciudad de México sufrieron cruelmente la crisis y la inestabilidad política, situación que fue reflejada en la revista Su majestad el hambre, escrita en 1915 por José María Romo, donde se evidenciaba el sufrimiento y la hambruna de la población a causa de los ataques de los frentes revolucionarios y federales. En aquel momento el gobierno capitalino carecía del suficiente poder para mantener el control en la sociedad. "Tanto villistas como zapatistas, obregonistas o carrancistas asistían al teatro. Las tropas que pasaban por la ciudad de México hacia otros escenarios de guerra, tomaban al [teatro] Principal como un descanso entre batallas". 194

Refiriéndonos a otro tipo de diversiones, un caso extraordinario es el que presenta Agustín Rivera y Corral, dueño de un casino, quien

[...] respetuosamente manifiesta que desea obtener permiso para jugar en el referido establecimiento los juegos permitidos por la ley y que están comprendidos en el artículo 7 del Reglamento Vigente, tales como ajedrez, paco, billar, poker, dominó y tresillo.

\footnotetext{
192 Pablo Dueñas, op. cit., pág. 136.

193 Ibidem, pág. 136.

${ }^{194}$ Socorro Merlín, Vida y milagro en las carpas, op. cit., pág. 18.
} 
Y a usted C. Presidente del Ayuntamiento, le suplica le conceda la licencia respectiva de la que siempre ha dispuesto el mencionado casino desde el año de 1909 y que sólo le fue suspendida por el C. Secretario de Gobierno, durante el régimen Zapatista.

Constitución y Reforma México, Julio 12 de $1915 .{ }^{195}$

En este caso se puede observar cómo cuando los frentes revolucionarios tomaban el poder de la ciudad también reaccionaban de forma represora contra las diversiones de las élites.

Retomando una de nuestras hipótesis de que el teatro de revista fue un elemento importante para la difusión de los principales acontecimientos del país, al finalizar la segunda década del siglo XX, se reconoció la importancia de las revistas políticas, debido a lo cual se publicaron artículos que coincidían con los escritores en donde se mencionaba que era indispensable lograr la libertad de expresión en las representaciones teatrales, ${ }^{196}$ por lo que durante la presidencia de Adolfo de la Huerta se estimuló al espectáculo teatral.

Para 1921 algunas carpas comenzaron a regalar boletos a las escuelas para distribuirlas entre los alumnos como estímulo. ${ }^{197}$ Asimismo los empresarios del teatro Rivapalacio decidieron regalar semanalmente 300 entradas a las fábricas y grandes talleres, para que fueran repartidas entre los obreros más cumplidos y éstos pudieran asistir con su familia al teatro. Otros industriales establecieron convenios mediante los cuales los dueños de los teatros se comprometían a aceptar grupos de trabajadores, ofreciéndoles espectáculos que los mantuviesen alejados de las tabernas. ${ }^{198}$

En 1921 Miguel Lerdo de Tejada, entonces jefe de la Sección de Diversiones, propuso crear la Comisión Cultural y Artística de la Ciudad de México, la cual debía

procurar la elevación de los espectáculos públicos; encauzar a las diversas compañías de teatro y al público mismo, hacia diversiones cada vez más cultas y refinadas; fomentar la

\footnotetext{
195 AHDF, Fondo: Ayuntamiento; Sección: Diversiones públicas; vol. 807; exp. 1312.

${ }^{196}$ Armando de Maria y Campos, Teatro de género chico, op. cit., pág. 238.

197 AHDF, Fondo: Ayuntamiento; Sección: Diversiones públicas; vol. 808; exp. 1402.

198 Lucio Ricardo Martínez Marín, Del teatro a la Alameda. Diversiones públicas en la Ciudad de México durante el Porfiriato, Tesis de licenciatura en Historia, UAM-I, México, 1991, pág. 35.
} 
afición social por las grandes audiciones sinfónicas y corales, promover espectáculos en que, aprovechando las artes decorativas y musicales de la raza, se haga estética con lo nuestro, con lo mexicano, persiguiendo con ello echar los cimientos del verdadero arte nacional. ${ }^{199}$

Por una parte el Ayuntamiento trataba de promover una cultura refinada, sin embargo era evidente el éxito de las representaciones populares y del género político. "O el público no podía prescindir del tema político en las revistas y zarzuelas, o los autores no se atrevían a presentar sus producciones son el cuadro político que actualizaba sus producciones". 200 Mientras tanto los autores siempre estaban al tanto de los acontecimientos políticos.

Arturo Ávila escribió una obra titulada ¡Ni Calles!, ¡Ni Huerta!, ¡Ni Flores!, cuyo nombre aludía a los precandidatos presidenciales durante la época en que los dos últimos estuvieron a punto de llegar a candidatos. "El público acudió al teatro Lírico esperando una obra de carácter político, y sólo se encontró con una revista en la que las tiples bailaban y cantaban como tal o cual flor, vestidas con ropas que evocaban ejemplares de la flora mexicana". ${ }^{201}$ Como el público gustaba tanto de la revista política los mismos títulos resultaban un gancho para llenar los teatros, sin embargo no siempre resultaban conformes con lo representado.

El año de 1920 es el punto que marca una transformación en la vida social, política y cultural de México, ya que la lucha armada llega a su punto final. Y en el espacio teatral estrena la revista 19 y 20, justo el 31 de diciembre de 1919, con autoría de José F. Elizondo, ${ }^{202}$ cuya trama aludía a que era tiempo de que el país dejara las armas y volviera a la tranquilidad, en uno de los cuadros se exaltaba la figura de Porfirio Díaz como "héroe de la paz", lo cual provocó cierta noche una

\footnotetext{
199 Informe de Miguel Lerdo de Tejada a Herminio Pérez Abreu, 13 de julio de 1921. Citado por Aurelio de los Reyes, Cine y Sociedad en México 1896-1930. Vol. II. Bajo el cielo de México, op. cit., pág. 105.

${ }^{200}$ Armando de Maria y Campos, Teatro de género chico, op. cit., pág. 285.

201 Ibidem, pág. 296.

202 Alejandro Bullé Goyri Ortiz, "Confrontaciones y coexistencias en la renovación teatral mexicana en la primera década del México posrevolucionario (1920-1931)", en Israel Franco y Antonio Escobar Delgado (coordinadores) El teatro de Ahora: un primer ensayo del teatro político en México, CONACULTA, México, 2011, pág. 268.
} 
lluvia de proyectiles que culminó con la clausura del teatro Principal y el arresto de Elizondo junto con su equipo de producción. ${ }^{203}$

En 1921 se creó en el Ramo de Diversiones del Ayuntamiento un Departamento llamado "Inspección cultural y artística", ${ }^{204}$ el cual se encargó de informar al Ayuntamiento sobre la calidad de los espectáculos antes de ser exhibidos públicamente. Esta Inspección se formó por críticos de arte, intelectuales y personajes de criterio con el fin de que las obras que se desearan representar cumplieran con las normas morales y políticas, y que el costo de la misma fuera acorde con su calidad teatral.

En ese mismo año un inspector reportó una obra que consideraba indecente por el contenido comunista:

Es verdaderamente lamentable ver como nuestros actores teatrales desprestigian cada vez más el género mexicano [...] No pueden prescindir de los diálogos léperos y tienen especial empeño en hacer de dichas obras un motivo de relajamiento moral. Así es la obra de Humberto Galindo "La Bandera RojiNegra" [...] El argumento de esta zarzuela consiste en un bolshevique que viene a México para propagar sus ideas comunistas, pero comprende que aquí no se puede progresar porque todo se toma a la guasa [...] La obra a que me refiero sobrepasa los límites de esa tolerancia y debería reformarse o suprimirse de plano [...] El público demostró su poca cultura silbando el desfile de banderas internacionales que se hace en el último recuadro.

Inspector José M. Mendoza. ${ }^{205}$

En el expediente se adjunta el libreto de la obra donde se tachan los diálogos que se consideran indecentes, no existen más documentos que especifiquen si se prohíbe o se reforma el contenido de esa obra, sin embargo se evidencia cómo los autores no cuentan con suficiente libertad de expresión y sus libretos tienen que pasar por la aprobación de las autoridades del Ayuntamiento.

Ese mismo año, con motivo de los festejos del centenario de la consumación de la Independencia, se propone una convocatoria a escritores de teatro con el fin de motivar a los autores de género revisteril y se aboquen al

\footnotetext{
203 Pablo Dueñas, op. cit., pág. 141.

${ }^{204}$ AHDF, Fondo: Ayuntamiento; Sección: Diversiones públicas; vol. 808; exp. 1411.

${ }^{205}$ AHDF, Fondo: Ayuntamiento; Sección: Diversiones públicas; vol. 808; exp. 1413.
} 
género dramático, ${ }^{206}$ no se especifica si en realidad se abrió la convocatoria, sin embargo no damos cuenta de cómo las autoridades tratan de detener el auge del teatro de revista.

Por otra parte los mismos políticos aprovechaban el auge del teatro de revista para hacerse propaganda, como lo hizo Álvaro Obregón en la campaña para su reelección, ya que le pagó ocho mil pesos al escritor Carlos Gustavo Villenave y cinco mil a Roberto Soto como reconocimiento al apoyo que había recibido durante su campaña de reelección. En otro momento

Enrique Alonso señala que Obregón les obsequió este parlamento: "Digan que el mejor candidato es Obregón porque sólo tiene un brazo; por lo tanto sólo tiene cinco uñas. Es decir: va a robar menos." Por la noche, el candidato a la presidencia de la república se presentaba a la función y a la hora en que los actores decían su chiste, el público guardaba un incómodo silencio, pero Obregón era el primero en soltar una sonora carcajada; entonces la gente le aplaudía de pie. Obregón, desde su palco, agradecía la fina atención de los actores. $^{207}$

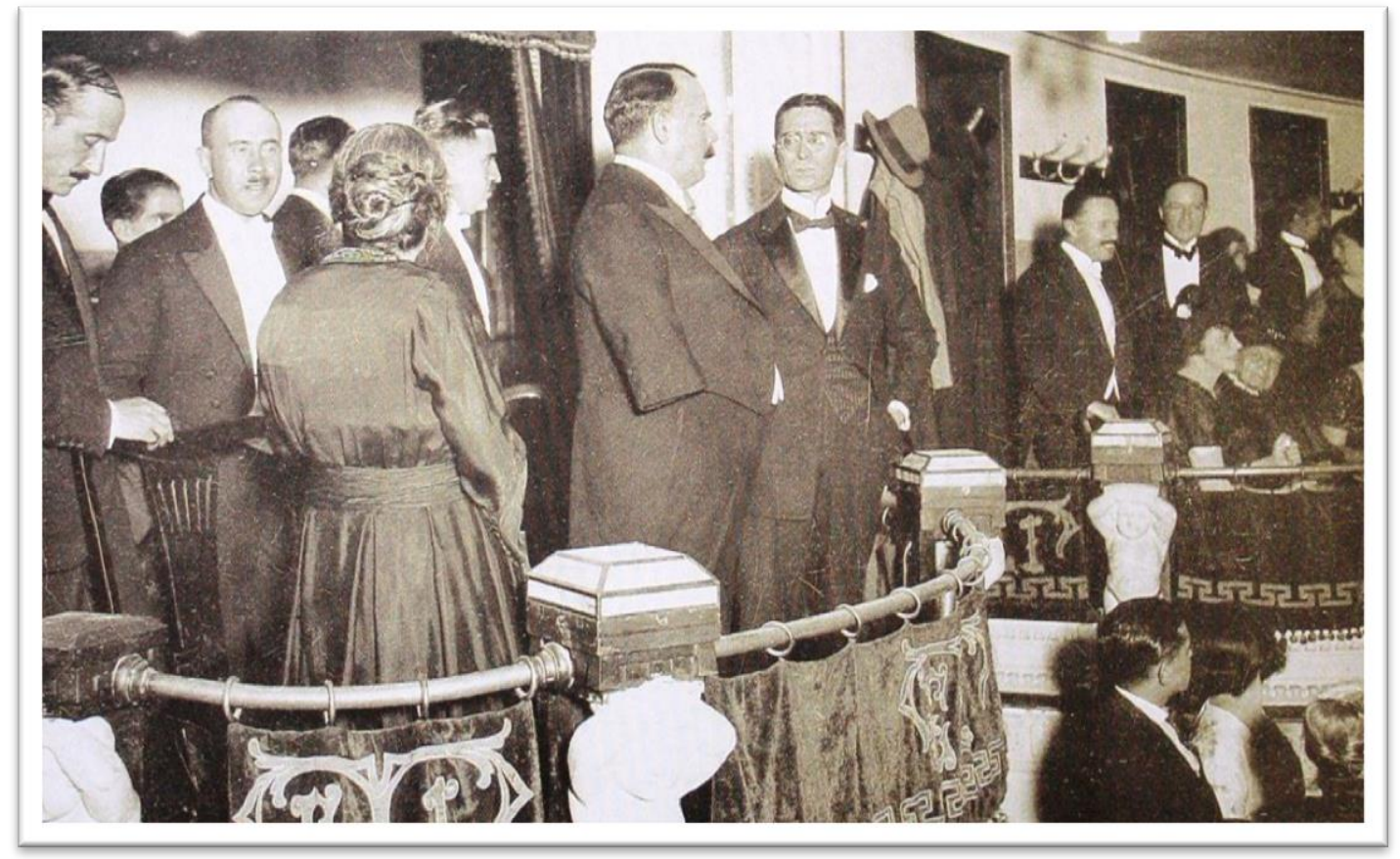

Álvaro Obregón desde el palco de un teatro.

Fuente: Fototeca AGN.

${ }_{207}^{206}$ AHDF, Fondo: Ayuntamiento; Sección: Diversiones públicas; vol. 808; exp. 1415.

207 Josefina Estrada, op. cit., pág. 43. 
De esta forma las revistas eran un medio de difusión idóneo para las ideas políticas de la época, sólo que los autores debieron de tener cuidado a quien beneficiaban y a quien criticaban, ya que por lo abrupto de los acontecimientos un día podían gozar de buena libertad, mientras que al ligero cambio político podían sufrir represión.

Las revistas retomaban tan rápido los temas de actualidad, una muestra de ello es que el 30 de noviembre de 1924 cuando Plutarco Elías Calles protestó como presidente, esa misma noche fue estrenada en el teatro Garibaldi La Herencia del Manco, de Emilio Cabrera, ${ }^{208}$ que trataba de manera superficial el tema de cómo había llegado Calles al poder ayudado por Álvaro Obregón.

La lucha cristera fue un tema poco tratado en el teatro de revista debido a la moda del bataclán introducido al país en 1925, y los autores se tenían que avocar a escribir libretos para el espectáculo que en ese momento prefería la población. Sin embargo cuando la moda pasó, los autores siguieron escribiendo revistas políticas.

Otro hecho retratado por el teatro de revista fue el asesinato de Álvaro Obregón en 1928 en el restaurante "La Bombilla" a manos de José León Toral, una de las supuestas autoras intelectuales del homicidio fue la abadesa Concepción Acevedo de la Llata, mejor conocida como "Madre Conchita". Aún con lo delicado del suceso, se estrenó en el teatro Lírico la revista La concha madre, de Carlos G. Villenave, de la cual Armando de Maria y Campos nos narra un cuadro fundamental:

En una taberna donde abundaban los valentones y asesinos que habían sido villistas, no faltó el fanfarrón armado que se dirigiera a los presentes diciendo "El que toque a esta mujer, lo mato." Nadie se atrevía a hacerlo, hasta que entraba un viejo y escuálido mandadero, que se dirigía a la mujer, tomándole del brazo para pedirle algo. El valentón se irritaba: "Dije que el que se acercaba a esta mujer se moría. ¡Rece su última oración! ¿Cómo se llama usted?" El aludido contestaba tranquilamente: “José León Toral." Y esto bastó para que todos salieran en estampida, dejando al anciano solo en la taberna. De la bolsa sacaba

${ }^{208}$ Armando de Maria y Campos, Teatro de género chico, op. cit., pág. 301. 
dos huevos de gallina y los ponía en el mostrador diciendo: ¿por qué se habrán espantado?” Entre carcajadas y aplausos, caía el telón. ${ }^{209}$

Más tarde se estrena en el teatro Lírico Naipes políticos, una revista de José Moreno Ruffo y Joaquín Pardavé donde aparecían varios personajes, entre ellos: Tengan su imposición (Aarón Sáenz), Cyrano de Villa Real (Antonio Villareal), Según te Portes Gil (Emilio Portes Gil), el Tío Sam, Vas con celos y vienes con ambiciones (José Vasconcelos), El Rubio Pascual (Pascual Ortiz Rubio) y el general Calles, representado por Joaquín Pardavé, quien siempre ganaba las partidas. ${ }^{210}$

Durante el periodo del Maximato, con motivo de la renuncia a la presidencia de Pascual Ortiz Rubio, se estrenó La hora de renunciar, ${ }^{211}$ revista escrita por Carlos G. Villenave, donde se aludía el tema de las renuncias presidenciales como consecuencia de los intereses políticos en pugna.

En el transcurso que gobernó Emilio Portes Gil se mandó expulsar del país a tres escritores de teatro de revista política: Carlos G. Villanave, Rodolfo el "Chamaco" Sandoval y Juan Díaz del Moral, ${ }^{212}$ como forma de precaución para que no escribieran obras que evocaran un ataque al régimen de entonces, sin embargo cuando regresaron al país siguieron incursionando en el medio.

En 1929 el teatro es beneficiado por el gobierno de la ciudad de México, junto con el apoyo de la escritora y funcionaria Amalia C. de Castillo Ledón, para entonces se creó un programa de teatro popular denominado "Recreaciones Populares del Departamento del Distrito Federal", que consistió en llevar espectáculos a zonas marginadas o populares de la ciudad mediante el establecimiento de una gran carpa donde se representaban obras como Obreros y Oro Negro de Francisco Monterde. ${ }^{213}$

En 1933 Abelardo Rodríguez ordenó realizarse una "Feria Nacionalista" en donde se ofrecieron distracciones populares. "Aquí el término "distracciones"

\footnotetext{
${ }^{209}$ Pablo Dueñas, op. cit., pág. 145.

${ }^{210}$ Alfonso Morales, op. cit., pág. 43.

${ }^{211}$ Armando de Maria y Campos, El teatro de género chico, op. cit., pág. 366.

212 Pablo Dueñas, op. cit., pág. 146.

${ }^{213}$ Alejandro Ortiz Bullé Goyri, “Confrontaciones y coexistencias”, op. cit., pág. 275.
} 
queda muy bien, pues el último gobierno del "Maximato" estaba recibiendo en este año las mayores demostraciones de descontento con las huelgas de trabajadores en demanda de mejores salarios". ${ }^{214}$ Para esta feria se convocó a todas las carpas de la ciudad de México, así como a otro tipo de diversiones callejeras, se establecieron a lo largo de la Alameda y hasta el Zócalo.

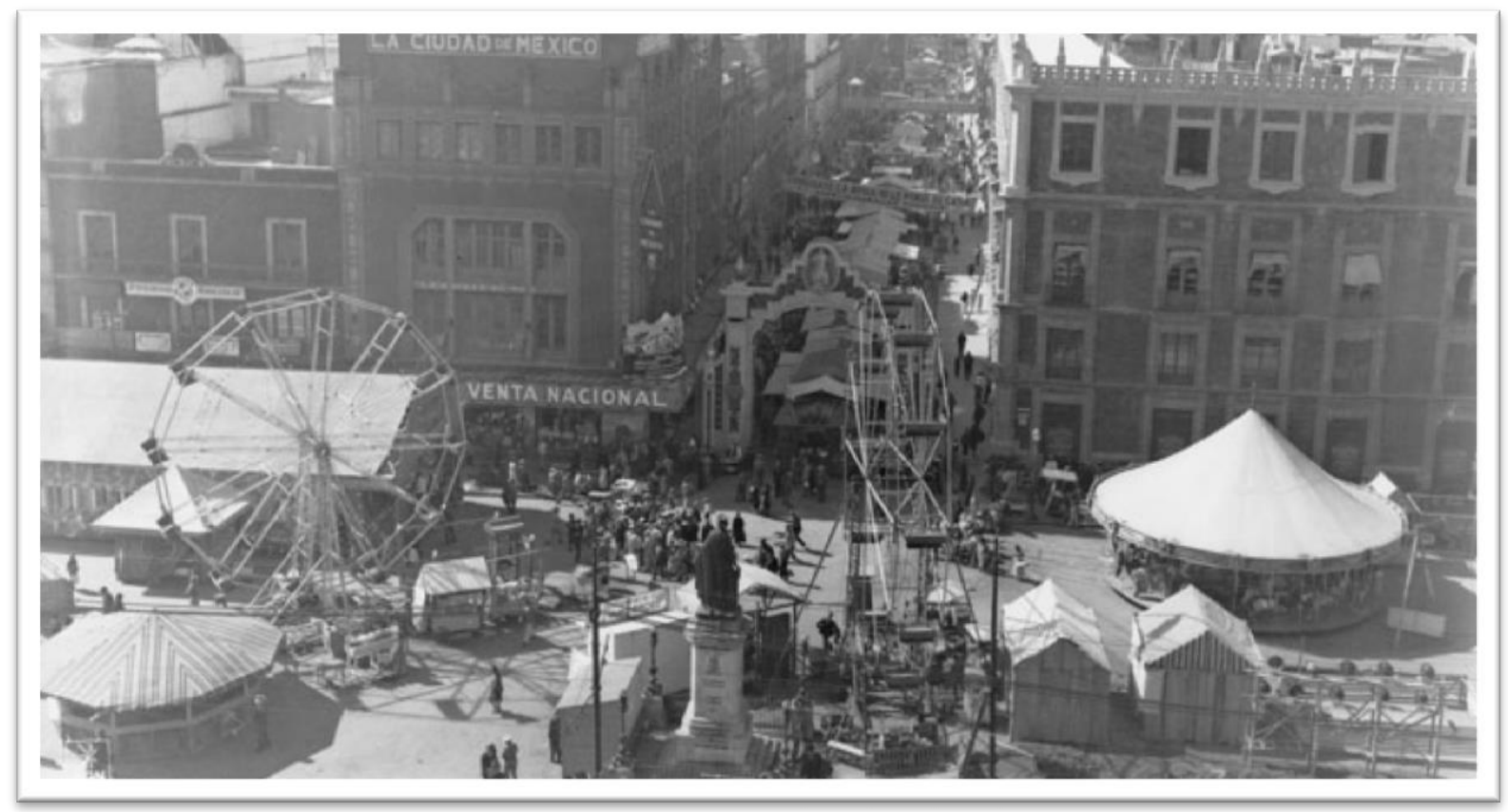

Entretenimientos durante la semana nacionalista a un costado de la Catedral.

Fuente: Colección particular.

Los gobiernos posrevolucionarios tendieron a la institucionalización del sistema de dominación política. "Para ello era necesario incorporar políticamente a los grupos más importantes de las clases populares, pero manteniendo sobre ellos un control indiscutible a fin de no perder la iniciativa política". ${ }^{215}$ Uno de los sectores populares más importantes fue el obrero, el cual se corporativizó por medio de la Confederación de Trabajadores Mexicanos (СтM). Incluso fue el primer sector en incorporarse al Partido Nacional Revolucionario (PNR) en 1936. ${ }^{216}$

\footnotetext{
${ }^{214}$ Socorro Merlín, Vida y milagros de las carpas, op. cit., pág. 27.

${ }^{215}$ Lorenzo Meyer, "La institucionalización del nuevo régimen", en Historia general de México, El Colegio de México, México, 2000, pág. 825.

${ }^{216}$ Ibidem, pág. 857.
} 
Los trabajadores del teatro no se escaparon de formar parte del sistema corporativo. A mediados de la década de 1930 los actores y empresarios de carpa formaron la "Unión de Artistas de Variedades y Similares", integrada también por músicos de las carpas, utileros, teloneros y los famosos gritones. Posteriormente esta organización se unió con la "Sociedad de Actores" ${ }^{217}$ y así se fundó en 1939 la Asociación Nacional de Actores (ANDA), personajes como Jorge Negrete y Mario Moreno Cantinflas, fueron muy importantes para el reconocimiento y bienestar de los actores de carpa. ${ }^{218}$ Dentro de la ANDA las diferentes especialidades carperas se distribuyeron de acuerdo con las secciones existentes en la asociación como cantantes, payasos, cómicos, entre otros puestos. ${ }^{219}$ La ANDA estaba afiliada al Sindicato de Trabajadores de la Industria Cinematográfica (STIC) que pertenecía a la Confederación de Trabajadores de México (CTM). ${ }^{220}$

Tal vez podríamos decir que los actores, al estar integrados al sistema corporativo, no manifestaron grandes críticas al régimen. Mientras tanto, el gobierno de Lázaro Cárdenas favorecía el desarrollo de las carpas, ya que las consideraba espacios benéficos para el entretenimiento de la población, debido a lo cual se concedían permisos sin demasiados trámites. "Bastaba encontrar un terreno baldío y tener con qué construirla, para montar una [...] El general sabía la importancia que tenía la carpa como espacio en donde se reunía el pueblo de pocos recursos de la ciudad de México y la protegía". ${ }^{221}$ Incluso se cuenta que el presidente era admirador del actor Chicotito, por lo que le regaló una gran carpa. $^{222}$

Durante el gobierno cardenista los autores escribían obras que enaltecían al gobierno del presidente, como San Lázaro el milagroso, representada en 1936 por Cantinflas en el teatro Follies. Otras fueron: El tenorio rojinegro, Un bolchevique en la presidencia y Laza los cárdenos. Ese mismo año cuando Plutarco Elías Calles fue expulsado del país por criticar súbitamente al gobierno cardenista se

\footnotetext{
${ }^{217}$ Pedro Granados, op. cit., pág. 141.

${ }^{218}$ Socorro Merlín, Vida y milagro en las carpas, op. cit., pág. 28.

219 Ibidem, pág. 36.

${ }^{220}$ Fidel Ángel Espino, Clavillazo. Cuando las manos hablaron, Diana, México, 1989, pág. 190.

${ }^{221}$ Socorro Merlín, Vida y milagro en las carpas, op. cit., pág. 28.

222 Pedro Granados, op. cit., pág. 77.
} 
estrenaron: Dinamita a don Plutarco, la huelga de Calles, Se solicitan Callistas de Xavier Navarro, El jurado de Calles, de Manuel M. Ortega, y El judío errante, de Villenave, donde Roberto Soto apareció en el papel del judío Plutón Elías. ${ }^{223}$

Incluso durante el gobierno de Cárdenas se abren las puertas del Palacio de Bellas Artes al género revisteril, y para entonces Roberto Soto con su gran compañía teatral llena el "jacalón de mármol" 224 con Rayando el sol. Se puede decir que esta situación marco el punto cumbre del teatro de revista.

Precisamente porque ha seguido un incesante proceso evolutivo y no es fruto de la improvisación no del oportunismo, el espectáculo que actualmente ofrece, en el majestuoso recinto que es gala y orgullo de la capital de la República, puede considerarse como una síntesis apoteósica del género que por varios años ha cultivado con tanto fervor como esmero. ${ }^{225}$

Al final del gobierno de Cárdenas se estrenó Los últimos días de Nerón, como si fuera el final del régimen benévolo a la población. Si bien durante el periodo cardenista no se tuvo mayor problema con la libertad de expresión dentro de los teatros, mucho se debió a que, en su mayoría, el discurso revisteril fue benéfico al régimen. Sin embargo con la llegada del siguiente gobierno los autores volvieron a derrochar la tinta sobre los acontecimientos políticos, y de nuevo se encontraron las medidas represoras del régimen.

Durante la campaña de Manuel Ávila Camacho el compositor de revistas teatrales Manuel Castro Padilla fue golpeado un grupo de avilacamachistas al finalizar la revista La razón de la pistola, de autoría de Ortega, Prida y Castro, representada en el teatro Lírico, el cual fue apedreado; días después el compositor murió debido a una pulmonía y probablemente a las consecuencias de la golpiza recibida. ${ }^{226}$ El $1^{\circ}$ de diciembre de 1940 Manuel Ávila Camacho asumió la presidencia, y de una manera aquel incidente fue una prueba de la intolerancia que le avecinaba a la revista política. Incluso durante su mandato las obras

\footnotetext{
${ }^{223}$ Pablo Dueñas, op. cit., pág. 148.

${ }^{224}$ Alfonso Morales, op. cit., pág. 95.

${ }^{225}$ Revista de revistas, 2 de mayo de 1937.

${ }^{226}$ Armando de Maria y Campos, Teatro de género chico, op. cit., pág. 409.
} 
trataban los temas de actualidad con mucha precaución ya que a cualquier crítica al régimen recaería la severa represión.

Un personaje que bien puede ilustrar la represión revisteril en aquella época es Jesús Martínez Palillo, de quien se dice que tenía que cargar con un amparo en la bolsa, porque cada vez que terminaba su función, un policía lo esperaba en la puerta del teatro para llevarlo a la cárcel. ${ }^{227}$ Dedicarse a la crítica política le costó ser encarcelado en 11 ocasiones y visitar nueve veces el hospital. Él mismo comenta:

Cuando estuve en el Colonial tuve pleitos con Alfonso Brito y con la policía, ahí comenzaron mis metidas a la cárcel, supuestamente por faltas de respeto a la autoridad, pero como no me podían comprobar me dejaban libre. En una de ellas me hicieron pasar en el bote una navidad. Fue en 1940 a causa de una crítica al régimen del presidente de ese entonces, Ávila Camacho, me metieron en la sexta demarcación a las once de la noche del 22 de diciembre y me soltaron hasta el 27 , dormí en la misma cama de cemento donde durmió Goyo Cárdenas, el padre [...] El jefe de la policía, el coronel Martínez, me persiguió con saña. Una vez mandó detenerme durante un sketch que mezclaba policías y rateros, fui llevado a la sexta demarcación y encarcelado nueve días. Después me hizo llevar a su oficina, me interrogó y yo no le contesté, entonces me sonó dos bofetadas, y yo, con las manos espesadas, no pude más que escupirle. Sangrando fui a dar nuevamente al calabozo [...] Una vez me les escapé por la azotea a unos cuicos, en ese entonces no azules sino con un ridículo uniforme de un gris muy oscuro, con grandes cinturones. Los cuicos se morían de coraje así que a la siguiente se subieron al escenario y me agarraron adentro, la gente estaba divertidísima, creía que era parte del sketch; no sabía que estaría yo refundido en la patrulla roja que me había esperado afuera del teatro. ${ }^{228}$

Durante el régimen avilacamachista algunas revistas seguían aludiendo a temas políticos como Los tiempos de Ezequiel, que hacía referencia al ex candidato a la presidencia Ezequiel Padilla; y Chimino vs. Lombardo, en la que se presentaban diálogos sobre las ideas del General Maximino Ávila Camacho y el líder de la CTM,

\footnotetext{
${ }^{227}$ Yolanda Bravo Saldaña, “De la carpa al cine”, en Mexicanísimo. Abrazo de una pasión, año 3, no. 29, pág. 52.

${ }^{228}$ Sebastián Armando González de la Vega, op. cit., pág. 36.
} 
Vicente Lombardo Toledano. A este último personaje se hizo alusión en otra revista titulada El líder que forjó una huelga. ${ }^{229}$

Una revista hizo mención a algo relacionado con el presidente Ávila Camacho fue La feria de San Manuel, escrita por Rodolfo Sandoval, ${ }^{230}$ que representaba cuadros alusivos a la feria de Tezuitlán, Puebla, lugar de nacimiento del presidente. Dicha obra no representaba peligro para el régimen ya que no contenía sentido político alguno.

En 1946 durante la campaña presidencial de Miguel Alemán, las revistas de carácter político únicamente se representaron en el teatro Lírico. La realización de obras de este género comenzó a bajar abruptamente, esto se relaciona directamente con el gusto por el nuevo teatro de variedades (números musicales, actos de magia y acrobacias sin mensajes políticos) y la revista romántica (dramas románticos), la población ya no deseaba ver acontecimientos políticos en el escenario y durante ese año no se registraron revistas con temas políticos en alguno de los teatros de la ciudad, lo cual refuerza otra de nuestras hipótesis, de que con la consolidación del aparato corporativo y la hegemonía de los regímenes posrevolucionarios, el teatro se despolitiza, como medio de control sobre las diversiones públicas.

Una de las últimas revistas políticas que se realizaron fue El cuarto poder, estrenada en el teatro Lírico en 1948, ocasionó un escandaló que hizo que se mandara a cerrar el teatro por órdenes del jefe de la Oficina de Espectáculos haciendo uso de la fuerza pública. Al instante se reunieron en asamblea los integrantes de las agrupaciones sindicales que integraban la Federación teatral Asociación Nacional de Actores, Unión de Autores, Unión de Apuntadores, Unión de Representantes y Organizadores de Espectáculos, Sindicato de Compositores, Unión de Empleados, entre otros - y acordaron un cierre total de todas las salas de espectáculos como protesta por la clausura. Las autoridades argumentaron que se clausuró el recinto porque los empresarios se negaban en quitar de la representación los contenidos obscenos y permitir que en otras funciones de la

\footnotetext{
${ }^{229}$ Armando de Maria y Campos, Teatro de género chico, op. cit., pág. 413.

${ }^{230}$ Ibidem, pág. 411.
} 
temporada la exótica Yara bailara casi desnuda, y por otros contenidos políticos en la obra. ${ }^{231}$

Por su parte, el regente de la ciudad Ernesto Peralta Uruchurtu atacó todo aquello que le pareciera inmoral, combatió el género popular en los teatros, prohibió decir piropos y besarse en la calle, los desnudos en escena y en las películas, disminuyó los horarios de cantinas, cabarets y salones de baile, además de ordenar el cierre de varios de ellos. La política moralizante desarrollada por el gobierno capitalino se hacía bajo la bandera de ser una medida necesaria para la defensa del salario del trabajador, pero en realidad resultaba una forma de sometimiento para la población, ya que el proceso de industrialización alcanzado hasta entonces necesitaba una fuerza de trabajo cada vez más disciplinada, cuya energía corporal debía depositarse en el trabajo y no en la diversión. ${ }^{232}$

Mientras tanto durante la presidencia de Miguel Alemán, el país se industrializó de manera acelerada y las instituciones creadas después de la Revolución tuvieron se consolidaron ampliamente. Es en este periodo cuando se crea el INBA (Instituto Nacional de Bellas Artes), por medio del cual se le dio apoyo a las artes a través de los intelectuales que obtuvieron puestos en el gobierno. ${ }^{233}$ Sin embargo sólo se impulsó la "alta cultura", no favoreció la cultura de la clase popular. Se consolidaron otros medios para llevar la cultura al pueblo "El género frívolo en carpas, teatros y cabarets ya no será el mismo después de 1950, adoptará otras formas de producción, de acuerdo con la asimilación de la tecnología, de los medios masivos y de nuevos símbolos que se integran a la modernidad a la que aspira el país". ${ }^{234}$ Rápidamente el radio y el cine se apropiaron de la representación sobre lo popular, y los actores cambian de escenario, detrás de un transmisor de ondas hertzianas o en el proyector de una sala de cine, el público ya no guarda contacto directo con ellos, de lo cual se hablará en un apartado posterior.

\footnotetext{
${ }^{231}$ Ibidem, pág. 446.

${ }^{232}$ Amparo Sevilla, Los templos del buen bailar, op. cit., pág. 92.

${ }^{233}$ Socorro Merlín, Vida y milagro en las carpas, op. cit., pág. 39.

234 Ibidem, pág. 40.
} 


\section{VIDA COTIDIANA Y PERSONAJES EN LAS CARPAS}

En este capítulo se analiza la dinámica vivida en el teatro popular desde una perspectiva más cercana a los espacios, personajes y público. Es importante conocer los lugares donde se llevaron a cabo las representaciones teatrales de manera popular y su adaptación en el espacio urbano como forma de identificarse con la población a la que iba dirigida en diferentes momentos de la historia de la ciudad de México.

En el primer apartado se pretende hacer un análisis de la vida cotidiana dentro de las carpas y el lenguaje característico representado en ellas a partir de una comparación entre los teatros para la élite y los escenarios itinerantes. Esto nos ayudará a conocer la relación público-actor, elemento fundamental para entender el sentido y objetivos del teatro popular, que lo diferencia del teatro dirigido a las elites en donde la interacción es más alejada e individualista.

En el siguiente apartado se analiza la personalidad de algunos actores de carpa, que mantienen cierta uniformidad en la representación de tipos de la cultura popular urbana, con los cuales el público se sintió identificado, razón en la cual radicó su éxito. Asimismo se aborda la relación que estos personajes guardaron con el público en un espectáculo que los mantenía unidos personalmente, y cómo se fue perdiendo esta relación cuando el teatro popular fue decayendo y los actores encontraron lugar en otros medios de entretenimiento donde el acercamiento con el público ya no se realizaba de la misma forma.

\section{ESPACIO DE INTERACCIÓN}

Es importante hacer notar la diferencia entre el público de un teatro de élite y el de una carpa. Luis $\mathrm{G}$. Urbina, poeta y crítico de teatro, hace su particular descripción de un teatro de élite a fines del siglo XIX y principios del XX:

La concurrencia que asiste al teatro Hidalgo - un teatro cómodo, aseado y risueño como un burgués en domingo - es sencillota, jovial, honrada, y se compone en su mayor parte, de los pacíficos moradores de aquel lejano barrio [...] El público del Hidalgo, como lo tengo dicho, es honrado y de buena fe; ha dejado la tienda, el taller, el hogar tranquilo, para venir a 
solazarse delante de un tablado donde la virtud triunfa del vicio, la inocencia del crimen, y el débil del fuerte. ${ }^{235}$

Por otra parte, el mismo escritor describe al público de los jacalones desde un enfoque marginal como "quienes sólo podían pagar unos cuantos centavos por una o dos tandas de revista, en un teatrillo maloliente". ${ }^{236}$ Los cronistas teatrales de prestigio no se interesaban en realizar las crónicas de los teatros de barrio ya que "consideraban de poco valor hablar de "teatruchos" y jacalones modestos en publicaciones y periódicos de la "gente decente", cuando lo hacían, no dejaban de evidenciar que eran "sucios y repugnantes". 237 El propio gran cronista de teatro Armando de Maria y Campos se refiere a las carpas y a su público de una manera denigrante:

En esa época [1905], en el lado septentrional de la Alameda existían dos grandes jacalones de madera en estado casi ruinoso, con bancos del mismo material en su interior, circundado por unos palquillos muy horribles y con un pequeño forito hasta el fondo, donde se daban funciones de marionetas o títeres, herederos de los hermanos Rosete Aranda, representando trasuntos populares, siempre fastidiosos y tontos. En la tarde, y hasta hora temprana de la noche, el baboso espectáculo constituía un entretenimiento para los pequeños y un pretexto para citas de niñeras o gendarmes, o de mozalbetes groseros y muchachuelas descaradas, sin que por ello faltaran algunas señoras y caballeros decentes $y$ de provecta edad que iban a platicar vulgaridades, a chismorrear de curas y sacristanes y a dormirse. Pero el panorama cambiaba totalmente desde las nueve hasta las doce de la noche o más tarde, porque su concurrencia era de gente trasnochadora, viciosa, bravía y pintoresca. $^{238}$

Por su parte, Enrique de Olavarría y Ferrari hace referencia a cómo los cinematógrafos se multiplicaban, ganando terreno a las carpas: "no tardaron en propagarse en toda la capital, contribuyendo y no en pequeña escala a retirar de inmundos jacalones y sucios teatrillos a gran pare del público que buscaba recreo

\footnotetext{
${ }^{235}$ Luis G. Urbina, "La semana”, en El mundo ilustrado, México, 9 de abril de 1899, en Merlín, Socorro, Teatro y política en la obra de Marcelino Dávalos, INBA, México, 2011, pág. 28.

${ }^{236}$ Idem.

${ }^{237}$ Pablo Dueñas, op. cit., pág. 34.

${ }^{238}$ Armando de Maria y Campos, Las tandas del principal, op. cit., pág. 168.
} 
en las asquerosas pornografías de las zarzuelas del género chico, y proporcionando honesta y agradable a las familias de buena sociedad [... $]^{239}$

Mientras que de un teatro de élite se poseía la imagen de un lugar elegante, limpio, ordenado y para gente educada, de un jacalón o carpa se tenía la idea de un espacio precariamente construido, insalubre, sin orden y destinado a población marginada y sin educación.

Los espacios se pueden evidenciar visualmente revisando fotografías de época. Los grandes teatros de la ciudad como el Hidalgo, el Arbeu, el Principal, entre otros, son construcciones monumentales estilo neoclásico, se nota cómo llegan las personas en automóviles, los interiores son bastante amplios y elegantes, la vestimenta del público es refinada y el escenario es grande, pero distante de los espectadores, lo cual guarda también otro sentido, como lo menciona Carlos Monsiváis: "Un palco es una posición geopolítica, un lugar de privilegio que exhibe y ratifica una posición social. El clasismo de los teatros es consagratorio y las diversiones en luneta, palcos, anfiteatro y cazuela o galería refieren con crueldad otros procesos". ${ }^{240}$

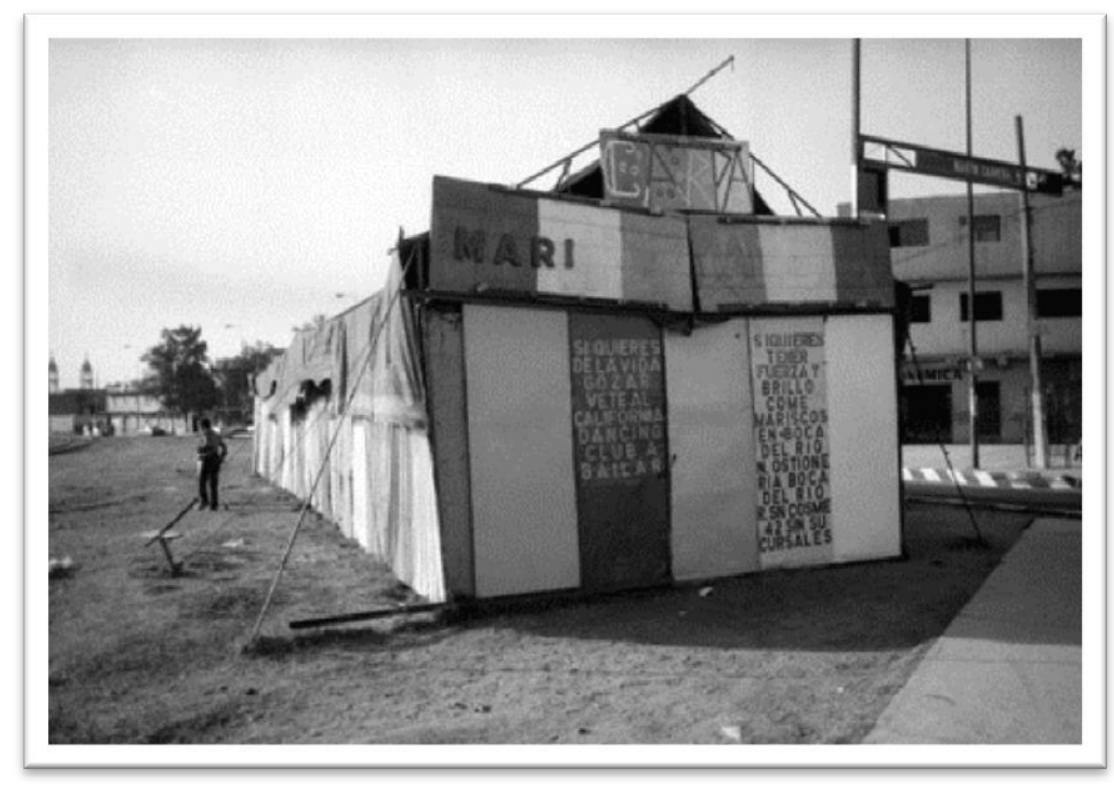

Teatro de carpa construido con materiales austeros

Fuente: Fototeca INAH.

${ }^{239}$ Enrique de Olavarría y Ferrari, Reseña histórica del teatro en México. 1538-1911, volumen v, México, Porrúa, 1961, pág. 3096.

${ }^{240}$ Carlos Monsiváis, “Notas sobre la cultura mexicana en el siglo Xx”, op. cit., pág. 1066. 
Por su parte, los teatros de carpa se visualizan instalados en espacios abiertos como lotes baldíos o plazas públicas, sus materiales evidencia claramente su instalación momentánea e itinerante, construidos con madera, láminas de asbesto o lonas al estilo circense, su interior se aprecia pequeño, con sillas movibles, muchas veces sin orden. Asimismo gran parte del público permanece de pie, la vestimenta de los espectadores da cuenta de una clase trabajadora con sus overoles puestos, aunque también hay personas con traje y sombrero, y rara vez se muestran personas con atuendo indígena, en estos lugares no existe considerable separación entre el escenario y el público, lo que evidencia una interacción actor-espectador más íntima. Pedro Granados, quien convivió de cerca con el ambiente de carpas los describe y recuerda cómo se anunciaban las funciones:

Las bancas de las carpas se hacían con tiras de madera, pero muy resistentes, cabían 10 o 12 personas por banca, pero con buena voluntad aguantaban hasta 14 [...] Al frente de las carpas, antes de comenzar la función, se ponían los músicos. Trompetas y timbales muy estridentes para llamar la atención del público y tres o cuatro gritones anunciaban: ¡Aquí pasen a ver al gran Conde Boby, a Celia Tejeda, a la gran Eva Peralta por solo 10 centavos!, ¡sólo estando muy lámparas no pasarán a verlos!, jesta y l’otra por un solo boleto! ${ }^{241}$

En numerosas ocasiones las carpas no podían protegerse de manera adecuada ante las inclemencias del tiempo, como lo testimonia un documento de 1922, "en la carpa Minerva, el día 7 antes de principiar la función y por fortuna sin que el público hubiese entrado a la carpa, un fuerte viento reventó las guardas del mástil y esto obligó a la Empresa a derribar la lona de dicha carpa suspendiéndose por tal motivo la función anunciada". ${ }^{242}$ En el mismo sentido, otro reporte menciona que las carpas Jesús Torres, India Bonita, María Conesa y Cardineti

están bajo un mismo sistema, esto es compuestas de una cubierta de lona, en mal estado en todas ellas, excepto en la primera que se está poniendo de nuevo. Esta cubierta, debido a su mal estado, no pueden remediarla bien, y cuando llueve generalmente se pasa, y el público tiene que estar cambiando de lugar, para encontrar un sitio donde no se pase el

\footnotetext{
${ }^{241}$ Pedro Granados, op. cit., pág. 55.

${ }^{242}$ AHDF, Fondo: Ayuntamiento; Sección: Diversiones públicas; vol. 812; exp. 1669.
} 
agua de la lluvia. La parte del escenario por lo regular está en peores condiciones que el resto, habiendo algunas en que por el viento que sopla, se ha desgarrado y se encuentra en el foro por completo al aire libre. Las mantas que forman digamos las paredes de la carpa en unas están algo mejor que las otras, pero en ninguna está en estado del todo satisfactorio.

Por lo que hace a pavimento, unas tienen en la parte de luneta una tarima más o menos mal arreglada, pero que cuando menos da mucho mejor aspecto y comodidad que donde no existe [...] las sillas están sueltas y cuando llueve el público las lleva a sitios donde no se moja haciendo desaparecer todo orden y no quedando como es natural ningún pasillo para el tránsito así que es al desalojar el local es verdadero desorden que se produce.

Como estos foros no tienen tampoco más pavimento que el suelo natural de donde están instaladas, resulta que los trabajadores y artistas, para ir a sus departamentos pasan por el agua que se ha metido al llover y por todas partes se encuentra encharcada esa agua. Excusados para el público y para el personal tampoco los tienen estas carpas, salvo la Jesús Torres, que cuenta con excusado provisional, que no tiene caja lavadora y se limpia con agua en cubetas. ${ }^{243}$

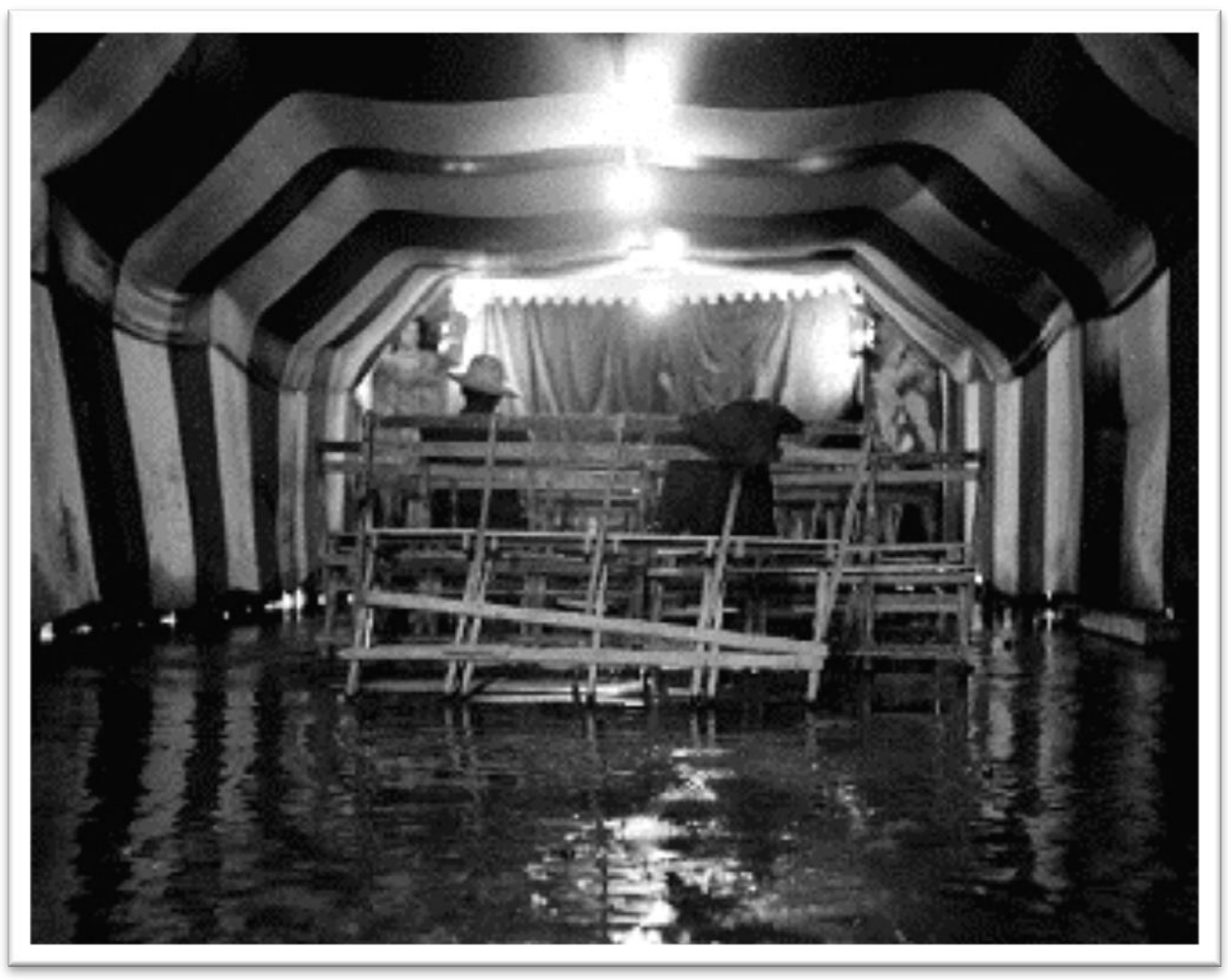

Interior de una carpa inundada.

Fuente: Fototeca INAH.

${ }^{243}$ AHDF, Fondo: Ayuntamiento; Sección: Diversiones públicas; vol. 812; exp. 1708. 
También hay quienes hacen una comparación de estos espacios con el pueblo: "La carpa está hecha a imagen y semejanza del pueblo de México. Participa de todas sus características. Es pobre. Se conforma con estar en cualquier lugar. Gusta mucho de cerrar el paso de las calles. Y de hacer ruido". ${ }^{244}$ Lo anterior nos proyecta la idea de un espacio que se adapta a las condiciones necesarias para divertir a las clases bajas, un teatro nómada que viaja de plazuela en plazuela, que busca dónde instalarse, así como la población que migra a la ciudad con el afán de encontrar un lugar dónde mejorar su calidad de vida. Asimismo se tiene una visión de estas carpas como lugares que dan mal aspecto a la ciudad, lo mismo que la élite piensa de la clase baja, como sectores de la población atrasados y que detienen el progreso del país.

Otra diferencia entre los dos tipos de teatro es la postura social adquirida 0 las intenciones de ir a divertirse. En los teatros de elite los asistentes acuden no solo para recrearse sino también para ser vistos ante las demás personas de su misma clase, y poner en evidencia que están en la vanguardia de las obras de moda. Por su parte, las clases bajas asisten al teatro popular porque ahí encuentran un espacio dónde sacar sus frustraciones y hacerlo de una manera colectiva, identificándose con los de su mismo estrato social.

Así como las carpas eran improvisadas, los actores también desarrollaron la habilidad de improvisar, "lo cual fue una característica exclusiva del espectáculo carpero, así como la trashumancia tanto de actores como del público, de una carpa a otra, de tanda en tanda, generando un espacio simbólico". ${ }^{245}$ Característica que marcó a las carpas como elementos diambulantes por los barrios marginados de la ciudad.

Como vimos en un apartado anterior, el sistema de vender el espectáculo por tantas y el éxito del teatro de revista hizo que las clases bajas tuvieran acceso a los grandes teatros, así el ambiente popular se mezcló con el "refinado", y las personas de clase baja empezaron a sentirse de un status social superior,

\footnotetext{
244 Manuel González Ramírez, citado en Hira de Gortari y Regina Hernández, Memoria y encuentros: La ciudad de México y el DF (1824-1928), tomo III, DDF-Instituto Mora, México, 1988, pág. 421.

${ }^{245}$ Romina Martínez, op. cit., pág. 115.
} 
mientras que la élite se manifestaba inconforme de que el pueblo tuviera acceso a los mismos espacios de recreación que ellos.

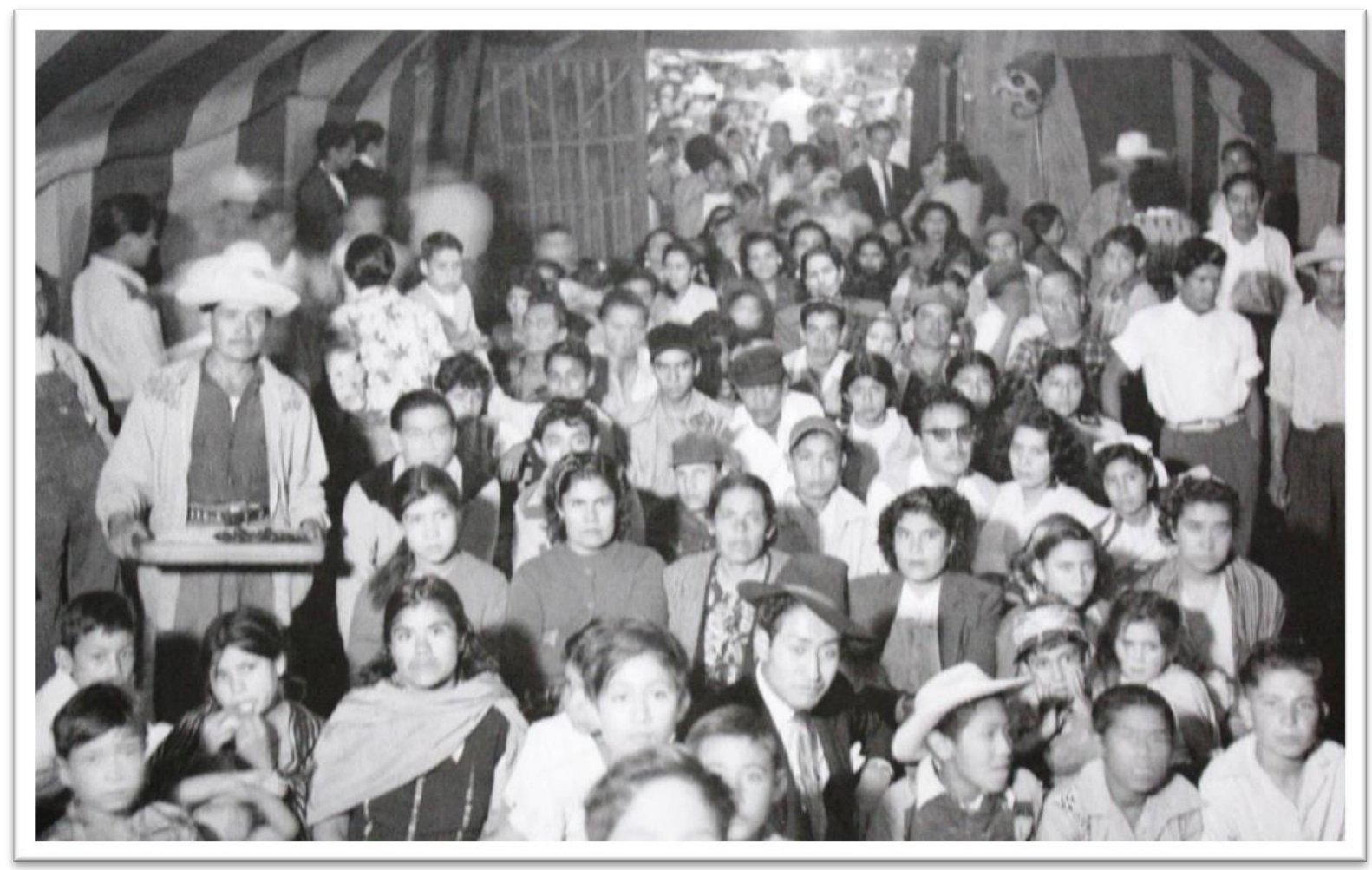

Público dentro de una carpa.

Fuente: Fototeca INAH.

Por otra parte, en el teatro de revista los asistentes no sólo adquieren el papel de receptores del mensaje que emiten los artistas, sino también se vuelven interlocutores que participan activamente en el espectáculo mediante un lenguaje popular. Los asistentes "hacen uso del albur y desaparece la distancia que existe entre el escenario y el espectador. Los actores mantienen diálogo con el público a veces demasiado agresivo. No sólo con el público de la sala, sino también con el político al que se hace alusión". ${ }^{246}$ Es precisamente durante la etapa del teatro político donde se manifiesta en gran medida este fenómeno, ya que con los múltiples acontecimientos en el país, el público utiliza el teatro como escaparate de sus sentimientos políticos.

\footnotetext{
${ }^{246}$ Claudia Martínez, El género chico o teatro de revista en nuestro país y su historia. Tesis para obtener el título de Actuación, Escuela de Arte Teatral, CNA, México, 1988, pág. 24.
} 


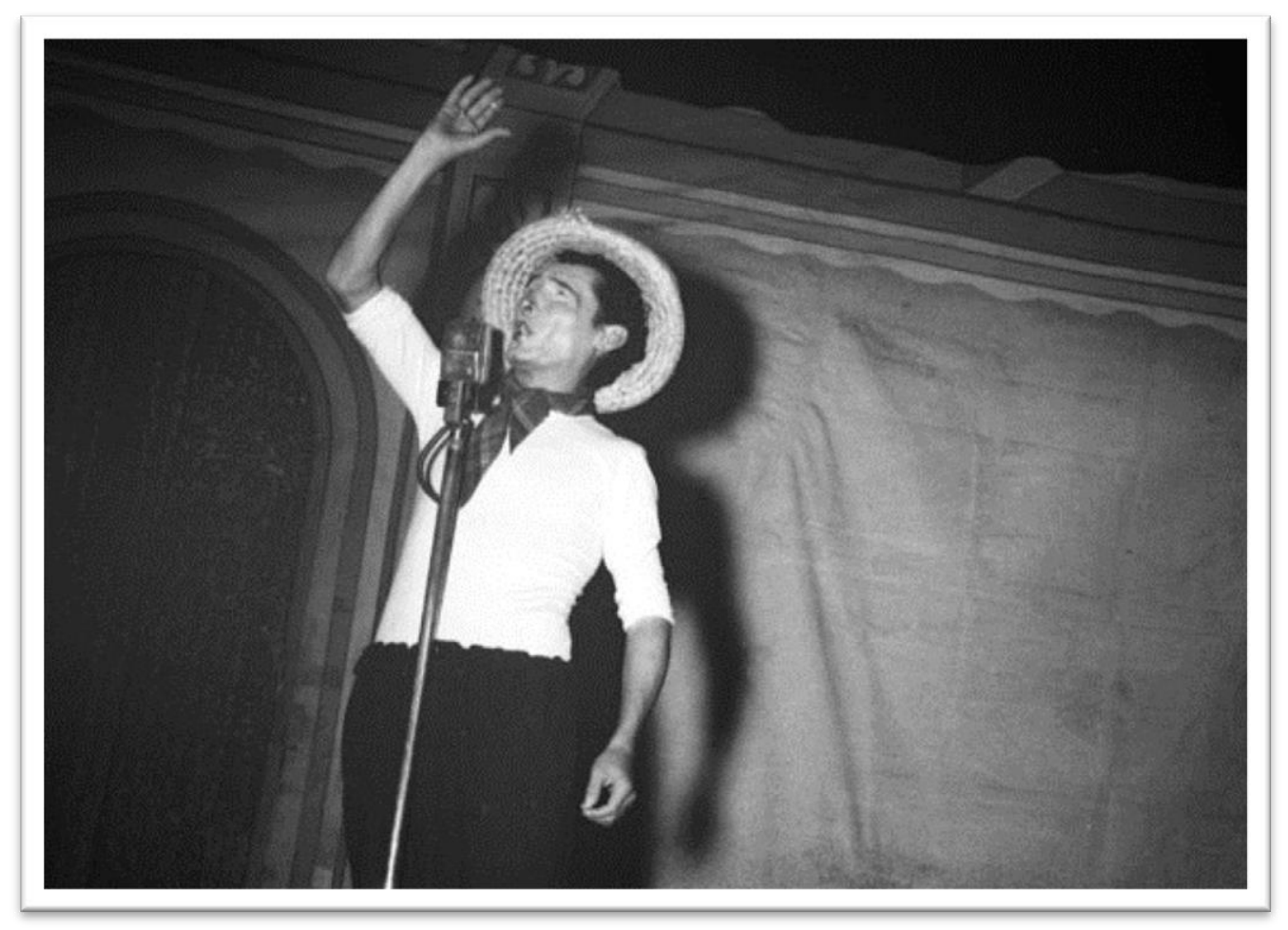

Palillo en una de sus representaciones dentro de una carpa.

Fuente: Fototeca INAH.

Los espectadores siempre fueron exigentes, demandaban un espectáculo que los entretuviera, por lo que castigaban a los artistas que no cumplían con sus expectativas a manera de abucheos, chiflidos o arrojándoles objetos. Debido a esto los actores siempre se esforzaban para tener satisfecho al público para evitar ser castigados. Esta relación entre público y actor también va de la mano de la infraestructura con la que se cuenta, Adalberto Martínez Resortes, comenta: "En las carpas que yo comencé a trabajar pues no había micrófonos, había que tener voz para dirigirse a la gente. Yo por eso soy un poquito fuerte para hablar, porque estoy acostumbrado a que me oigan las multitudes". ${ }^{247}$ La misma falta de medios hacía que la relación actor-público necesariamente fuera más cercana, cuestión que ya no se permitía en el cine, ni en el radio.

Hubo ocasiones en que el público se solidarizó abiertamente con los artistas que de alguna manera eran reprimidos por las autoridades, como fue el

\footnotetext{
${ }^{247}$ Entrevista con el señor Adalberto Martínez, realizada por Ximena Sepulveda el día 9 de octubre de 1978 en la ciudad de México. Archivo de la palabra PHO/2/86, Instituto Mora, México, 1985.
} 
caso de María Conesa, cuando un inspector de teatros le levantó una multa por cantar un cuplé "demasiado indecente". La noticia no tardó en llegar a los tandófilos, y al día siguiente apareció en los diarios una carta firmada por un grupo de admiradores en la que se decía a los inspectores que toda multa que se levantara a la tiple sería pagada por los ellos. ${ }^{248}$

En esta relación entre actores y público existe también otro ente, el personaje representado, quien de alguna manera tiene los medios para reprimir al actor. Se entera de las actuaciones en su contra por medio de los concejales que supervisaban las obras para cerciorarse de que se apegaran a los límites morales y de libertad de expresión. En muchos casos se manifestaron sanciones a los actores, mientras que en otros se utilizó el mismo teatro para propaganda hacia algún personaje político. Como es el caso de Leopoldo El cuatezón Beristáin, quien apoyó abiertamente dentro de sus actuaciones a Victoriano Huerta. ${ }^{249}$

La manera de comportarse en el teatro de élite distaba mucho de la que se tenía en una carpa. Armando de Maria y Campos nos describe el tipo de conducta de las clases acomodadas dentro del teatro Principal cuando existían retrasos para comenzar la obra:

Hasta en eso de la puntualidad para empezar las funciones a la hora anunciada eran otros tiempos aquellos. Empezaba la primera tanda a las 8:30; la segunda a las 9:30; la tercera a las 10:30, y a las 11:30 la última [...]. Un retraso provocó típica bronca que confirma la seriedad con que el público se comportaba [...] Como esto era un caso insólito en esa época y en ese teatro, y el público era intransigente, empezó el pataleo con ese golpear al unísono de los impacientes que, con pies, manos y bastones, producían un pam, pam, pam [...] tenaz y en aumento, hasta culminar en un ruido ensordecedor. ${ }^{250}$

El mismo cronista nos hace referencia de que a principios de siglo los jóvenes recibían educación para saber comportarse adecuadamente en los teatros, restaurantes, transporte y plazas públicas. Podemos saber cuál era el comportamiento permitido para las élites cuando una obra no era de su agrado gracias a lo que él encontró en los diarios de sus hermanas, que dicen: "Es de

\footnotetext{
${ }^{248}$ Luis Reyes de la Maza, Cien años de teatro en México, op. cit., pág. 153.

${ }^{249}$ Carlos Monsiváis, "Notas sobre la cultura mexicana en el siglo Xx", op. cit., pág. 1069.

${ }^{250}$ Armando de Maria y Campos, Las tandas del principal, op. cit., pág. 97.
} 
muy mala educación silbar a los autores y a los artistas; si la pieza, o la interpretación de ella, desagrada, puede manifestarse ese disgusto simplemente con el silencio". 251

Mientras tanto, dentro de las carpas no existían límites de comportamiento durante las funciones, con regularidad los asistentes buscaban la ocasión para manifestarse contra los comediantes de manera colectiva. Cuando los actores no lograban hacer reír al público, éste arrojaba objetos al escenario y gritaba de una manera reprobatoria. Un ejemplo de lo anterior lo demuestra una anécdota del personaje Clavillazo, quien en sus inicios no tuvo una aceptación del público: "Una rechifla fenomenal se escuchó y cuando Chumiate [primer nombre artístico de Clavillazo] empezó a hablar nervioso y atarantado una lluvia de jitomates llegó hasta el escenario a la voz de un grito que se escuchó en la sala:

- ¡A ese Chumiate un jitomate!"252

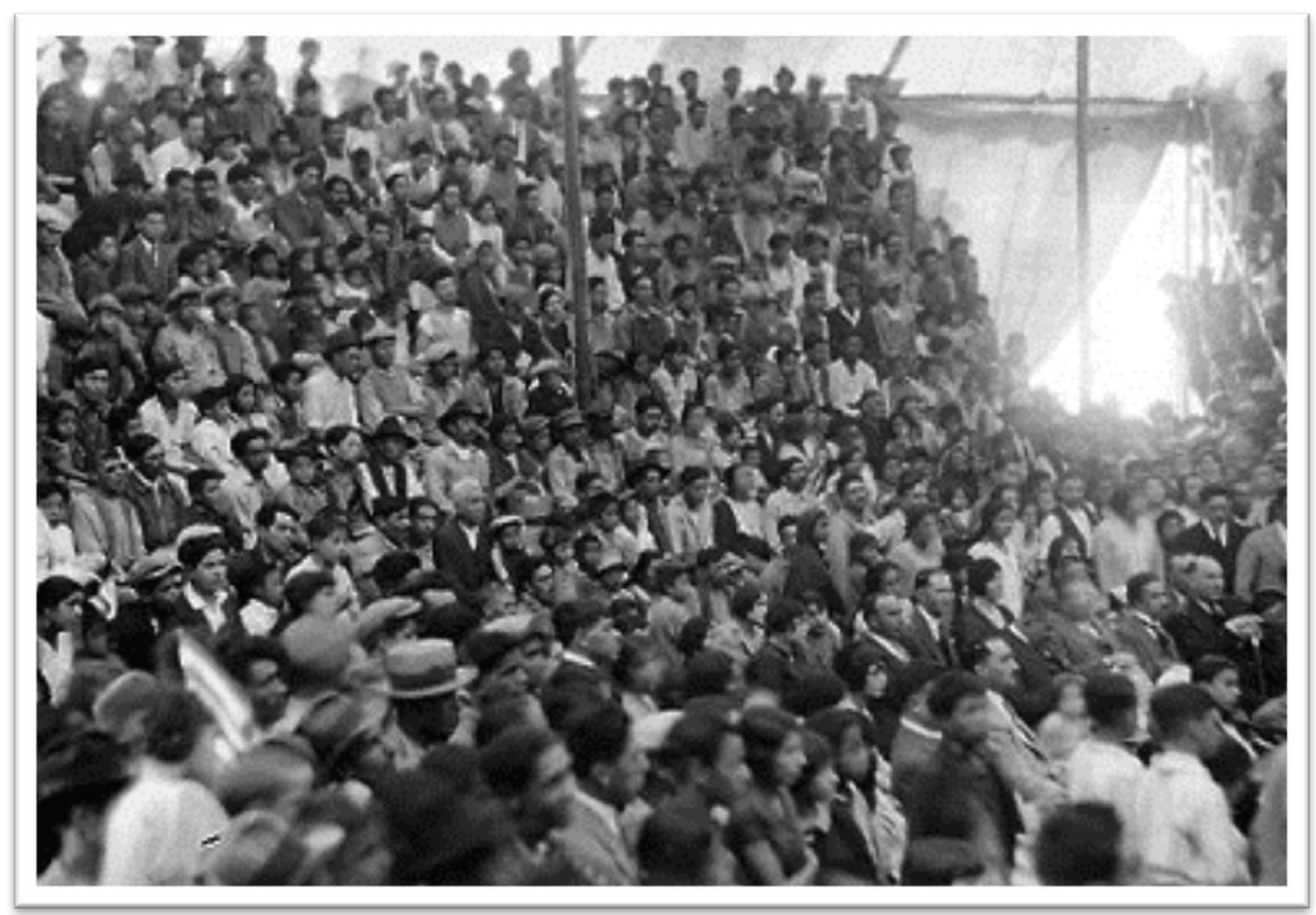

Público en el interior de una carpa.

Fuente: Fototeca INAH.

\footnotetext{
${ }^{251}$ Ibidem, pág. 133-134.

252 Fidel Ángel Espino, op. cit., pág. 147.
} 
Este ambiente corresponde a un espacio sui generis donde se vitaliza el lenguaje popular y lo grotesco se representa como realidad estética. ${ }^{253} \mathrm{El}$ teatro popular fue el espacio de interacción entre el público y los actores, quienes establecieron una nueva propuesta estética en el ámbito teatral. Luis Reyes de la Maza nos narra lo acontecido en algunos teatros:

En todos ellos había con frecuencia escándalos armados por los propios espectadores ante cualquier movimiento un poco más atrevido de las tiples o ante alguna copla de color subido que cantara el rencor cómico. El escándalo llegaba a su apogeo cuando se iba la luz, fenómeno frecuente en la capital desde la instalación de la electricidad hasta nuestros días. Entonces comenzaban los gritos, los insultos, las frases picarescas y las peleas entre espectadores de la galería. Una noche en el teatro Apolo el escándalo fue tan grande que las sillas comenzaron a llover desde las localidades altas hasta el lunetario, causando algunos heridos mientras el resto de la concurrencia trataba de ponerse a salvo alumbrándose con cerillos y con el riesgo de provocar un incendio. Otra noche en el teatro María Guerrero un borrachito se cayó desde la galería hasta el lunetario sin que le ocurriese daño alguno, motivo que aprovecharon los "hijos de la tanda" para armar tremenda trifulca. $^{254}$

"El lenguaje cargado de albures, de doble sentido en el que continuamente se pueden propasar incluso con "la santa madre", fue uno de los principales atractivos de las carpas. Es, en cierto sentido, la democracia del lenguaje donde todos han de ser albureados, donde la mayoría entiende el doble sentido, donde se habla "el mismo idioma". ${ }^{255} \mathrm{Si}$ bien este tipo de lenguaje sale de contexto, puede quebrantar las normas morales de la sociedad, sin embargo dentro de la carpa esto era totalmente cotidiano. Como lo menciona Carlos Monsiváis:

Dos espectáculos: uno en el escenario, donde se vierten los comentarios de la actualidad y se crean y esparcen los tipos populares; otro, el público, que agradece, insulta y conmina a actores y actrices, fuerza a una réplica, obliga a los cambios interminables en la representación, acosa con proyectiles y "leperadas" (la primera exhibición nacional del habla del "pelado", del idioma de las clases populares). Por vez primera, se quebranta parcialmente el culto inerte y pasivo el virtuosismo, la idolatría que - a falta de comprensión,

\footnotetext{
${ }^{253}$ Carlos Monsiváis, Historia mínima de la cultura en México, op. cit., pág. 456.

${ }^{254}$ Luis Reyes de la Maza, Cien años de teatro en México, op. cit., pág. 146.

${ }^{255}$ Romina Martínez, op cit., pág. 111.
} 
de la técnica, del sentido del arte - suscita inevitablemente toda exhibición a ultranza de una habilidad. Frente al virtuosismo que no consiente la menor participación, la plebe en la galería (la "gallola") eleva entre gritos obscenos su deseo de intervenir. ${ }^{256}$

El público actuaba de la misma manera al presenciar otro tipo de espectáculos dentro de las carpas, como lo testimonia el siguiente informe de un inspector:

En la carpa Ideal, a las 20:30, con motivo de la lucha de box, se formó un escándalo por el público, él amenazó con quemar la carpa haciendo pedazos algunas sillas; como el único gendarme no pudo evitarlo, recurrimos, el que suscribe y el C. Interventor Martínez, a llamar más policías, reuniendo veintidós con el piquete de la montada, con lo que acabó el escándalo. $^{257}$

Con lo anterior nos damos cuenta que el pueblo reaccionaba de una manera muy arrebatada. Las diversiones públicas ofrecidas no lograban recrear totalmente a la población. De la misma manera se puede obtener una idea sobre el ambiente de acuerdo a lo que José Clemente Orozco describe en relación a lo que acontecía en el teatro María Guerrero (conocido popularmente como María Tepache, debido a que en esa calle había varias tepacherías) en Peralvillo, a finales de la década de 1930:

El público era de los más híbridos, lo más soez del "peladaje" se mezclaba con intelectuales y artistas, con oficiales del ejército y de la burocracia, personajes políticos y hasta secretarios de Estado. La concurrencia se portaba peor que en los toros; tomaba parte en la representación, y se ponía al tú por tú con actores y actrices, insultándose mutuamente y alterando los diálogos en tal forma que no había dos representaciones iguales, a fuerza de improvisaciones. Desde la galería caían sobre el público de luneta toda clase de proyectiles, incluyendo escupitajos, pulque o líquidos peores $\mathrm{y}$, a veces, los borrachos mismos iban a dar con sus huesos sobre los concurrentes de abajo. Puede fácilmente imaginarse qué clase de obras se representaban entre actores y público. Las leperadas estallaban en el ambiente denso y nauseabundo y las escenas eran frecuentemente de lo más alarmante. ${ }^{258}$

\footnotetext{
${ }^{256}$ Carlos Monsiváis, “Notas sobre la cultura mexicana”, op. cit., pág. 1068.

${ }^{257}$ AHDF, Fondo: Ayuntamiento; Sección: Diversiones públicas; vol. 812; exp. 1706.

258 José Clemente Orozco, Autobiografía de José Clemente Orozco, Era, México 1970, pág. 38.
} 


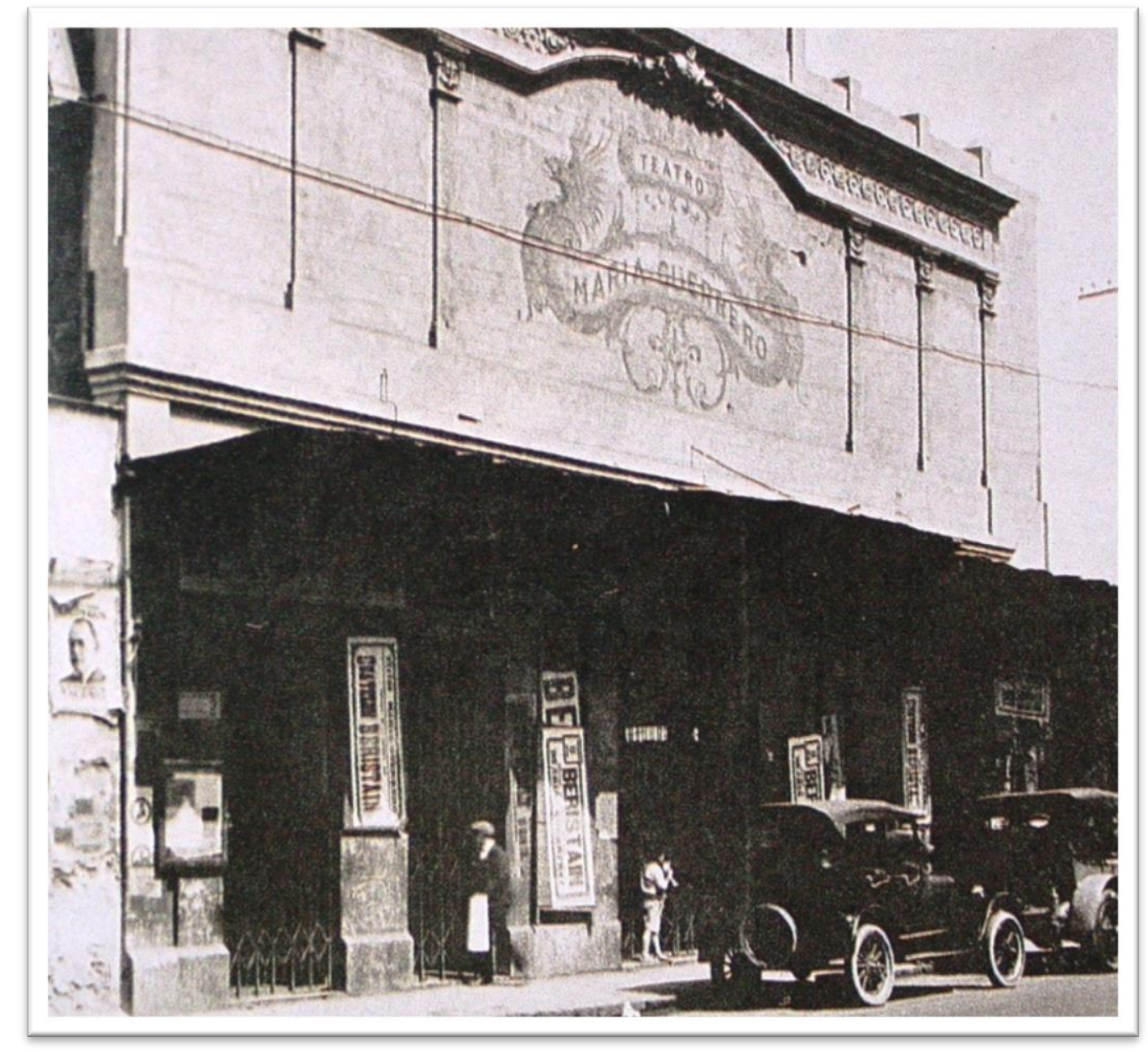

Teatro María Guerrero, conocido popularmente como María tepaches.

Fuente: Colección Gustavo García.

El éxito o fracaso de las obras radicaba la aceptación del público, "se entablaba un diálogo constante comprensible sólo para quien verdaderamente vivía, día tras día, la vida de la ciudad. ${ }^{259}$ El espectador se siente identificado con el actor, y viceversa, al momento de la satisfacción mutua, uno hace reír y el otro ríe, es el punto de encuentro entre los dos y la armonía popular expresada en la carpa. "Al aplaudir al autor o al actor, que dice y acciona el chiste que él hubiera querido decir en la calle o en la cantina, en la fábrica o en la oficina, se siente satisfecho y aplaude". ${ }^{260}$ Los actores y autores conocían bien el entorno de la clase baja, supieron expresar y comunicar lo que demandaba el público, siempre fueron vistos

\footnotetext{
${ }^{259}$ Guillermo Bonfil Batalla, prólogo en Alfonso Morales, El país de las tandas, op. cit., pág. 9.

${ }^{260}$ Armando de Maria y Campos, El teatro de género chico, op. cit., pág. 308.
} 
como héroes, ya que pudieron burlarse de los personajes opresores. Sabían perfectamente lo que necesitaba el público, y en eso radicaba su éxito al escribir los guiones. En palabras de Roberto Soto:

El pueblo mexicano tiene un refinado gusto y un sentido del humor verdaderamente extraordinario, que casi adivina lo que el actor va a decir. Sólo que necesita para su regocijo, que lo hagan entrar en dos rutas: el chiste político o la picardía. El primero es una válvula de escape. Cuando el pueblo no tiene oportunidad de decir su descontento y oye que alguien habla en voz alta por él, produce un desbordamiento de alegría. Cuando en lo administrativo o en lo social no está conforme con sus gobernantes, el chiste político viene a ser un desahogo, una satisfacción, un alivio muy grande. ${ }^{261}$

Para el público a esas alturas ya no es suficiente el chiste simple, es necesario que éste vaya aludido a un personaje o situación política. Al respecto el periodista José Natividad Rosales comenta: "he llegado a la conclusión de que el chiste político es la válvula de escape de un pueblo agobiado que no sabe escribir y mucho menos exponer de viva voz sus enojos". 262 Por esta razón al público le gustaba asistir al teatro, una vez que terminaba la función salía satisfecho al haberse reído de los personajes de la política representados por los actores. En palabras de Socorro Merlín "Las formaciones ideológicas gobiernan las formaciones discursivas, por lo que el aspecto ideológico es importante, como motivación para los dramaturgos en el acto de plasmar su estética en una obra de teatro". ${ }^{263}$ De tal modo que los discursos teatrales, en este caso, se forman en función a la ideología que impera en el momento, así como por la demanda de los espectadores al querer ver representado un tema político.

Como hemos argumentado, los espectáculos dentro de las carpas fueron muy importantes no sólo para entretener al público sino también comunicar los acontecimientos cotidianos. Dentro del periodo que nos ocupamos, el teatro de revista puede ser equivalente al corrido que "como género lírico y narrativo se ajustó maravillosamente a las necesidades informativas y de recreo de la tropa en guerra y de los ámbitos civiles refugiados en las principales ciudades [...] el

\footnotetext{
261 Ibidem, pág. 459.

262 Ibidem, pág. 460.

${ }^{263}$ Socorro Merlín, Teatro y política, op. cit., pág. 26.
} 
corrido cumplía con sus dos funciones básicas de aquel ejército y de aquella población civil: comunicaba y divertía". ${ }^{264}$ En la misma medida funcionó el teatro popular, los actores comunicaban, por medio de sus actuaciones, algunos acontecimientos sociales, interpretados de una manera satírica, mientras el público se entretenía y a la vez se informaba.

El teatro de género chico fue un detonante para el cambio en la comunicación cotidiana de la sociedad. Se vitalizó el habla popular mediante la introducción de palabras y la flexibilización del lenguaje a partir del uso del albur; la apropiación de "malas palabras" en el lenguaje cotidiano; asimismo lo grotesco se convirtió en un elemento estético y los acontecimientos políticos fueron comunicados por medio de las actuaciones dentro de las carpas, así como también se hacía por medio de caricaturas o corridos.

El lenguaje teatral en este ambiente adquiere un tono sarcástico haciendo mofa de los acontecimientos políticos del momento; "el desahogo de las distintas tensiones sociales como la revolución y la guerra cristera se dio a través de espectáculos de diversión como las carpas, en las cuales por medio del humor se liberaban críticas políticas y sociales" ${ }^{265}$ El público reía de los actores que representaban a personajes del gobierno, les aventaba objetos al escenario los insultaba como si fueran los personajes reales, de alguna manera canalizaba su odio hacia sus gobernantes riéndose de ellos. Puede ser que no les quedaba otra opción para manifestarse más que riéndose de personajes que representan a sus dirigentes.

\section{UNA IDENTIDAD POPULAR EN COMÚN}

La mayoría de los cómicos más destacados que actuaron en las carpas fueron personas originarias de barrios populares de la ciudad de México, aunque muchos otros nacieron en diferentes estados del país; y extraordinario es el caso de Estanislao Shilinsky, quien llegó a México procedente de Rusia junto con su hermano, en una compañía de circo, a partir de entonces se quedó a trabajar en el

\footnotetext{
264 Ricardo Pérez Monfort, Expresiones populares y estereotipos culturales en México. Siglos XIX y XX. Diez ensayos, CIESAS, México, 2007, pág. 54.

${ }^{265}$ Romina Martínez, op. cit., pág. 126.
} 
país y logró ser uno de los cómicos de carpa más representativos de la época. Sin embargo la mayoría de ellos compartieron una identidad en común que les llevó a ganarse el gusto de los espectadores.

Ya no eran los típicos charros o inditos de tinte folcklórico, característicos del teatro costumbrista. Muchos de ellos adquirieron una personalidad de payaso o mimo, que con el tiempo se fueron quitando el maquillaje, quedándose así con una vestimenta roída y sucia. Generalmente estos actores guardan relación con el personaje del pelado. Según Armando de Maria y Campos "Anastasio Otero Tacho, que en el año de 1910 era el mejor intérprete de los tipos del pueblo bajo mexicano, en particular el pelado arrabalero, y cuyo mérito es mayor porque creó estos tipos en los teatros del centro, fue, tal vez, un precursor del mexicano del pueblo bajo en escena". ${ }^{266}$ El surgimiento de este tipo de personajes logró el gusto por la gente, adquirieron una imagen de héroe y tuvieron mucho éxito, el público se sentía identificado con ellos porque representaban a personas de su misma clase. Reflejaron al sujeto urbano marginado, que con el uso de su astucia y mal lenguaje siempre salía librado, sin embargo nunca pasaba de pobre.

La imagen del pelado (el despojado de todo) que se relaciona lépero (el afligido por la lepra de la pobreza) del siglo $\mathrm{XIX},{ }^{267}$ corresponde a un estereotipo acorde a los personajes típicos regionales.

En muchas ocasiones la identificación de "lo típico" pretendió diferenciar una región de otra en materia de expresiones y costumbres festivas. Sin embargo, a lo largo de la segunda mitad del siglo XIX y la primera mitad del siglo XX algunas de estas manifestaciones festivas lograron imponerse como "típicas" no solamente de una región sino del país entero. Ese fue el caso de "el indito" y su chirimía, "el ranchero" en el jaripeo y la pelea de gallos, "el pelado" en la carpa, "el charro" o "la china poblana" con su Jarabe tapatío. 268

En el contexto de la carpa el pelado se convierte en un estereotipo de personaje dentro de la ciudad de México. Es un individuo que deja de ser campesino, pero que se encuentra inadaptado dentro de la urbe. Este personaje ha perdido su raigambre, posiblemente es el espejo de los migrantes que llegan a la ciudad,

\footnotetext{
${ }^{266}$ Armando de Maria y Campos, El teatro de género chico, op. cit., pág. 62.

${ }^{267}$ Carlos Monsiváis, Historia mínima de la cultura mexicana, op. cit., pág. 454.

${ }^{268}$ Ricardo Pérez Montfort, Expresiones populares y estereotipos, op. cit., pág. 122.
} 
dejan el campo y tratan de integrarse a la vida citadina. Al respecto Bartra menciona que "El pelado es la metáfora perfecta que hacía falta: es el campesino de la ciudad que ha perdido su inocencia original pero no es todavía un ser fáustico. Ha perdido sus tierras pero todavía no gana la fábrica: entre dos aguas, vive la tragedia del fin del mundo agrario y del inicio de la civilización industrial”. ${ }^{269}$ Este personaje obtiene mayor popularidad justo cuando el país se industrializa de manera acelerada, lo que hace que la población rural migre a las ciudades en crecimiento y empiecen a adaptarse a la dinámica urbana, no de manera fácil.

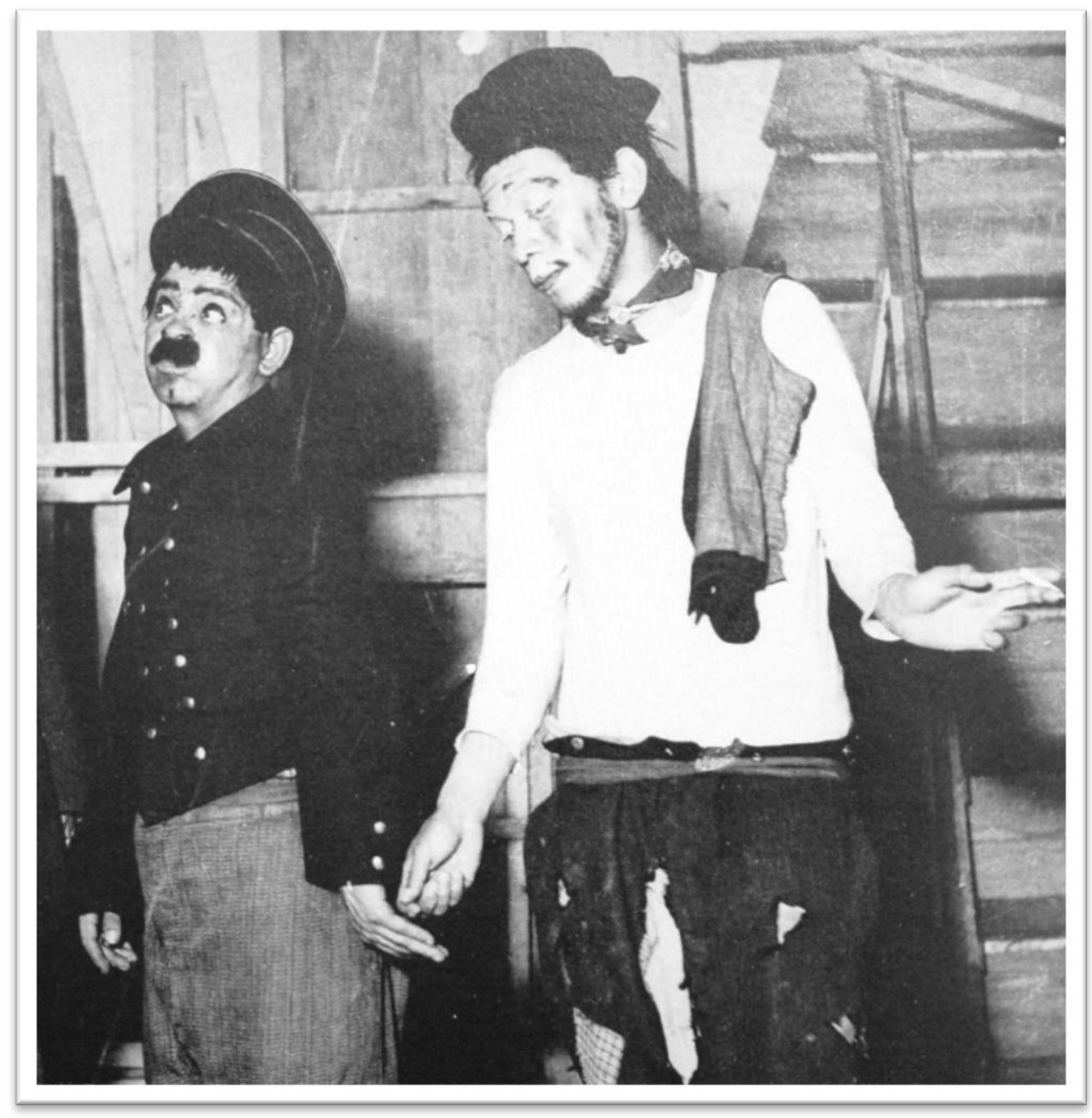

Caracterización de Cantinflas dentro de las carpas.

Fuente: Fototeca AGN.

\footnotetext{
${ }^{269}$ Roger Bartra, La jaula de la melancolía, Grijalbo, México, 1987, pág. 126,
} 
A modo de analogía entre el pelado y el pueblo, podemos considerar a Cantinflas a partir de dos atribuciones: por un lado, debido a su forma de vestir y sus hábitos hace alusión a un personaje de la clase baja; y por su discurso verbal que acapara la atención de su receptor, hace uso de un lenguaje complicado de coherencia inentendible parodiando la forma de hablar de los políticos. Incluso Armando de Maria y Campos al referirse al declive del teatro de género chico, argumenta que lo hace con una derivación cantinflista, ${ }^{270}$ en donde se representa la frustración verbal del analfabeta. Esta analogía entre el actor y el público, es una de las razones por las que el teatro popular tuvo éxito, pero que en el fondo sólo refleja la forma en que el pueblo se divierte burlándose de personajes que representan a él mismo.

Otra analogía interesante de Cantinflas se puede hacer con el Charlot de Charles Chaplin, personaje que también representa a una clase baja, pero "a diferencia de Chaplin, cuyo vestido de etiqueta revela una utópica voluntad de cambio, en Cantinflas no hay ninguna aspiración a superarse y «no quiere un mundo mejor ni como sueño; desea vivir como está»". ${ }^{271}$ Esta posición conformista puede ser atribuida al pueblo mexicano, se burla de los políticos pero no hace nada por transformar su realidad.

Por otra parte, estos actores buscaron una imagen acorde a su manera de actuación y cierta estética popular arrabalera. Adalberto Martínez Resortes comenta una de sus influencias para crear su personaje:

en aquel entonces pues la gente era más dicharachera, los personajes que vendían cosas, los vendedores ambulantes eran muy simpáticos, tenían su modo de gritar y de esas cosas yo agarré para el escenario; sí, porque yo me he reflejado en el pueblo y cuando hago mis personajes en la carpa y en el teatro, son reflejadas en el pueblo mismo que es lo que se siente el pueblo cuando se ve reflejado en el escenario, se siente que él está ahí, y si agarran una muchacha, el pueblo siente que lo está agarrando. ${ }^{272}$

\footnotetext{
${ }^{270}$ Luis Tavira, en Armando de Maria y Campos, Teatro de género chico, op. cit., pág. XVI.

${ }^{271}$ Roger Bartra, op. cit., pág. 166.

272 Entrevista con el señor Adalberto Martínez, realizada por Ximena Sepúlveda el día 9 de octubre de 1978 en la ciudad de México. Archivo de la palabra PHO/2/86, Instituto Mora, México, 1985.
} 
Como bien lo explica el actor, el público se sentía identificado con lo representado en el escenario. $Y$ a pesar de que en muchas ocasiones los asistentes ofendían y agredían a los actores aventándoles objetos, en el fondo los apreciaban.

Incluso hubo actrices que representaban a personajes femeninos de la clase popular, como Emilia Trujillo, quien caracterizaba a una borracha. De la misma forma lo hacían Amelia Wilhelmy y Delia Magaña, quienes posteriormente participaron en la película Nosotros los pobres desempeñando el papel de La guayaba y La tostada, par de comadres que permanecían todo el tiempo en estado etílico.

Un personaje que influyó de manera importante en la identidad de estos actores fue el protagonista de la tira cómica de Jesús Acosta, Chupamirto, que aparece en El Universal en la década de 1920, un tipo con el pantalón abajo de la cintura, camiseta de dormir de manga larga, el pedazo roto de un chaleco, y un pequeño sombrero hecho de papel. Algunos de los actores que retomaron la imagen de este personaje fueron: el Cuate Chon, Periquín, Chicote, Chupamirto y Clavillazo, pero el que más éxito tuvo fue Cantinflas.

Otro elemento que caracterizó a la mayoría de personajes fue su nombre artístico, muchos adquirieron apodos graciosos como Mantequilla, Resortes, Don Mamerto, Cuatezón, Clavillazo, entre otros. Este último utilizó diversos nombres: "Chumiate, Pipiolo, Polydor, Clavo, Clavito y por último Clavillo [...] Hubo varias opiniones y después de mucho batallar encontraron una combinación Clavillo y payaso y con una expresión de júbilo en todos los rostros el nombre fue descubierto: Clavillazo. ${ }^{273}$ Todos ellos trataron de encontrar un nombre con el que fueran reconocidos en el medio artístico y que causara simpatía en los espectadores, nombres que conservaron en las películas que realizaron.

Cantinflas fue un personaje de clase baja que se burló de personas como Luis N. Morones o Fidel Velázquez, figuras en ese momento con poder político en el país. La parodia política era del gusto de la gente, y los actores también querían inculcar en ellos una conciencia social, como explica Jesús Martínez Palillo: "Escogí la crítica política porque siempre fui un hombre de acción y de conciencia,

${ }^{273}$ Fidel Ángel Espino, op. cit. pág. 189. 
y porque es un género que invita a la gente a ser más despierta; nuestro pueblo se acostumbra a él y comprende mejor esa crítica hecha con ironía, sarcasmo y humorismo que la que pretende ser seria y pomposa". 274

Muchos personajes como Clavillazo, Resortes, Palillo, entre otros adquirieron vestimenta y personalidad equivalente a la del pelado, se expresaron con un lenguaje similar y aludieron a personajes políticos en sus representaciones, siempre caracterizando a sujetos de clase baja, o haciendo burla de la élite. Como argumentamos en un principio, varios de ellos tuvieron éxito al incursionar en el medio cinematográfico, otros no; y su discurso político en el cine cambió de manera sustancial. Sin intenciones de profundizar en la temática se ofrecerá un panorama general cómo fue el tránsito de algunos actores de carpa al espectáculo del celuloide y la respectiva transformación de sus discursos narrativos hacia la crítica política.

\section{LA CARPA, EL CELULOIDE Y LAS ONDAS HERTZIANAS}

Para la década de 1930 el teatro de revista poco a poco dejó de ser el espectáculo predilecto de la población debido a otro tipo de ofertas de esparcimiento. El cine fue una de ellas, que si bien su origen en México fue a finales del siglo XIX, no fue del gusto preferido décadas más tarde. Otra de las ofertas fue la radio, que creció de manera considerable; mientras en 1923 existían siete estaciones, para 1929 había 19 y 113 en 1940. De aproximadamente 25000 aparatos receptores en 1926, la mayoría en la ciudad de México y otras áreas urbanas, en 1950 ya había dos millones. ${ }^{275}$ Los aparatos de radio cambiaron radicalmente las reuniones familiares, se dejaron a un lado las pláticas para dar paso a que los oyentes disfrutaran de música, noticias, comerciales y entretenimiento.

El teatro de revista deja de ser gustado por la población, ya que no ofrecía algo innovador que lo hiciera sobresalir de las demás diversiones. Muchos artistas de carpa también participaban en el radio, incluso con las mismas intervenciones

\footnotetext{
${ }^{274}$ Sebastián Armando González de la Vega, op. cit., pág. 38.

275 Pablo Piccato, “Altibajos de la esfera pública en México, de la dictadura republicana a la democracia corporativa. La era de la prensa", en Leyva, Gustavo et al. (coordinadores), Independencia y Revolución: pasado, presente y futuro, UAM-FCE, México, 2010, pág. 278.
} 
en los dos espacios, por lo tanto, las familias preferían escuchar el espectáculo en la comodidad de su casa.

... en México, últimamente se ha cometido el error de hacer una revista "al estilo radio", y es lógico pensar que para oír "como en el radio" nadie va al teatro a pagar "dos pesos". Mejor se queda uno en su casa y oye sentado muellemente la voz de Toña... No, el éxito de las revistas está en que no se parezcan ni al radio ni al cine. ${ }^{276}$

¿Quién se va a divertir con una serie de canciones conocidas a través del radio, interpretadas por los mismos artistas que las cantan ante el micrófono y sin arreglarle un milímetro de teatralidad? Nadie. Si al menos la actuación de los artistas de radio cambiara en el escenario el caso sería distinto, pero así, es imposible. ${ }^{277}$

Las primeras transmisiones de radio retomaron los patrones del teatro de revista, combinaron música con actuaciones que alternaban el sentimentalismo y las escenas cómicas, incluso en su momento el público asistía al estudio de grabación, para presenciar el espectáculo, sin embargo las paredes y los micrófonos comenzaron a distanciar a los artistas de su público, ya no interactuaban como lo hacían en la carpa, ya no podrán aventarle objetos si no les agrada algo, se conformaran con escuchar y reír desde la comodidad de su casa. Además los cómicos, al ya no encontrarse físicamente frente a un público van perdiendo su capacidad de improvisación.

La industria radiofónica ofreció a los músicos y actores incluso pagos mayores de los que percibían en las carpas. "A partir de este momento la competencia entre las radiodifusoras impulsó a los artistas de carpa y variedad, que pasaron a formar parte de la industria privada del espectáculo que iniciaba con la "w", seguía con el cine y los cabarets y terminaría en Televisa". ${ }^{278}$ De esta manera se puede hablar del surgimiento de la industria del entretenimiento, la cual ha evolucionado hasta la manera de entretener por medio de la televisión hoy en día, con su gran potencial de difusión y penetración en la sociedad.

\footnotetext{
${ }^{276}$ El Universal Ilustrado, 12 de abril de 1934, pág. 11.

${ }^{277}$ El Universal Ilustrado, 19 de abril de 1934, pág. 12.

${ }^{278}$ Socorro Merlín, Vida y milagros de las carpas, op. cit., pág. 2.
} 
Por otra parte, los nuevos medios no ofrecían la misma libertad de expresión que se tenía en las carpas. La Ley de Comunicaciones Eléctricas supervisaba los contenidos de la radio

formulando claramente la prohibición de tratar de política. La prohibición era amplia y recuperaba la preocupación decimonónica por el honor al sancionar cualquier contenido que fuera contrario a la seguridad del Estado, a la concordia, a la paz, o al orden público, a las bunas costumbres, a las leyes del país y a la decencia del lenguaje, o que causen escándalo $o$ ataquen en cualquier forma al gobierno constituido o a la vida privada, honra o intereses de las personas. ${ }^{279}$

Las autoridades se afanaron en proteger los medios contra cualquier ataque al gobierno, sin embargo hubo ocasiones donde algunos actores políticos usaron la radio para sus intereses políticos como sucedió en noviembre de 1931, cuando "tres miembros del Partido Comunista (PC) secuestraron durante unos minutos los micrófonos de la XEW y celebraron el aniversario de la Revolución Rusa hablando contra el imperialismo y Calles" ${ }^{280}$, acto que seguramente fue reprimido por las autoridades. Incluso la radio fue usada por el gobierno para divulgar las ideas hegemónicas del momento; ese mismo año el PNR tenía su propia estación de radio $^{281}$, de la cual se valían para difundir los ideales del partido y las actividades de los gobernantes.

Otro medio de entretenimiento al que se desplazaron los artistas de teatro de revista, sobre todo las tiples, fue el cabaret, ya que les iba mejor económicamente al "acompañar" a clientes y ganar cierta cantidad de dinero por cada copa consumida.

Los artistas tienen que buscar otros medios de vida. Unos se van al cine, en donde muchos triunfan... Otros se esconden en los micrófonos de las estaciones radiodifusoras y otros, los frívolos de menor escala, van todas las noches a los cabarets a "fichar"... Y así vemos desfilar por ellos a muchas artistas que en esta nueva modalidad no tienen muchos ensayos

\footnotetext{
${ }^{279}$ Pablo Piccato, “Altibajos de la esfera pública en México”, op. cit., pág. 275.

280 Ibidem, pág. 275.

${ }^{281}$ Cristina Romo, Ondas, canales y mensajes: un perfil de la radio en México, ITESo, Guadalajara, 1991, pág. 20 citado en Pablo Piccato, “Altibajos de la esfera pública en México, de la dictadura republicana a la democracia corporativa. La era de la prensa", en Leyva, Gustavo et al. (coordinadores), Independencia y Revolución: pasado, presente y futuro, UAM-FCE, México, 2010, p. 276.
} 
y ganan más que en los teatros. Las que siguen en el teatro ven con un poco de desprecio a las que andan en los cabarets, pero éstas, en represalia, enseñan los pesos ganados a cambio de fichas y demuestran que obtienen mejores utilidades... Entran a los cabarets entre 11 y 12, salen a las 4 o 5 de la mañana y se pasan durmiendo la mayor parte del día, sin ver el sol, pero felices de no tener ensayos... A estas chicas que cobran una ficha por cada copa que piden o toman, es a las que en el "argot" de cabarets les llaman "ficheras"... Los sábados son días de verdadero éxito. No bajan de veinte o treinta las copas consumidas. $Y$ en veinte o treinta copas hay diez o quince pesos de utilidad. Por eso es que ya muchas segundas tiples teatrales están haciendo todo lo posible por entrar a la falange de las "ficheras"... La situación, empero, preocupa a los empresarios negreros verdaderos tratantes de pantorrillas - a cinco pesos diarios - porque con el alza de la carne blanca en los cabarets ¿Quiénes irán mañana a bailar en los teatros a medio sueldo y con ensayos? ${ }^{282}$

Mientras muchas tiples dejaban el teatro de revista para trabajar en cabarets, los artistas de carpa, como los escritores, dejaron su origen teatral para incursionar en los nuevos medios. Para la década de 1940 Joaquín Pardavé declaró que el cine y el teatro eran primos hermanos que se odiaban. Varios compañeros que habían trabajado con él en los escenarios lo tacharon de ingrato porque había abandonado el teatro. ${ }^{283}$ Los críticos de teatro auguraban el fin del teatro con el auge del cine:

¿Y el teatro? El pobre teatro se ahoga entre las bambalinas. Las compañías se forman y se desintegran de la noche a la mañana como burbujas de aire. Unos cuantos nombres van y vienen, mientras que otros - los que hicieron el teatro de ayer nada más - desaparecen de los escenarios para aparecer en la pantalla. ¿Por qué? Pues sencillamente porque ganan mucho más dinero en el cine que en el teatro. ${ }^{284}$

Por su parte, el cine fue el medio en el que convergieron muchos de los artistas exitosos de las carpas. En 1936 debutó Mario Moreno Cantinflas que, "avasallante en la carpa, es el inventor de la combinación exacta entre el manejo del cuerpo y la emisión armónica de frases sin significado". ${ }^{285}$ En el cine los cómicos mantuvieron su personalidad, y seguían siendo populares entre el público. Sin

\footnotetext{
${ }^{282}$ El Universal Ilustrado, 14 de diciembre de 1933, pág. 33.

283 Josefina Estrada, op. cit., pág. 51.

${ }^{284}$ Revista de revistas, 9 de enero de 1938.

${ }^{285}$ Carlos Monsiváis, Historia mínima. La cultura mexicana en el siglo XX, op. cit., pág. 326.
} 
embargo algunos otros no consiguieron el éxito esperado o simplemente no les interesó probar suerte en el nuevo medio.

Como argumentamos en una de nuestras hipótesis, estos artistas tuvieron gran éxito dentro de la población mexicana, situación que pudo aprovechar el gobierno posrevolucionario a través de la industria cinematográfica. "Al final, para las clases hegemónicas, los potencialmente peligrosos y revolucionarios pelados y proletarios terminan siendo unos personajes grotescos que sólo saben farfullar $\mathrm{y}$, en el mejor de los casos, expresar sus emociones cantando". ${ }^{286}$ Aquel personaje que nació burlándose de la clase gobernante posteriormente fue aprovechado por ella misma para entretener a la población. El Estado que en su momento utilizó al charro o a la china poblana como estereotipo de su nacionalismo, ahora retoma al pelado para representar al México posrevolucionario en proceso de industrialización a partir de la imagen de un personaje marginal urbano, que en la pantalla grande transforma el discurso político que lo caracterizaba dentro de las carpas.

Sin embargo no todos los cómicos de carpa se acoplaron a esta nueva dinámica de entretenimiento. Roberto El panzón Soto, a pesar de haber obtenido mucho éxito con su compañía de teatro de revista, no pudo relacionarse en el medio cinematográfico. Lo mismo pasó con Chicote, quien sólo figuró en papeles secundarios. Mención aparte merece Jesús Martínez Palillo, quien a pesar de haber realizado algunas películas, no tuvo el éxito que lograron muchos más, incluso él criticó al cine por no ser un espacio que permitiera la interacción entre el público y los actores:

En toda mi vida sólo hice tres películas cinematográficas, pésimas. Con decirle, en 1941 el primer llamado que tuve deben llevarse a los Estudios Clasa a dos agentes, pues yo no quería ir a presentarme a trabajar en Lo que el viento trajo por lo malo del argumento, pero ya había firmado y ni modo [...] las otras películas fueron también pésimas, mal dirigido, mal todo, Palillo Vargas Hereida de 1943 y Ay Palillo no te rajes de 1948, no son para recordarlas. Me ofrecieron no contarles nada y al final las mutilaron [...] la agresividad de Palillo no la vieron nunca, y el mundo me mandó al basurero cinematográficamente hablando. "No la vayan a ver porque está horrible", prevenía al público en los teatros [...] Y

\footnotetext{
${ }^{286}$ Roger Bartra, op. cit., pág. 168.
} 
es que no podían decirme "icorte! se repite esto", yo estaba acostumbrado a encarar al público y sobre lo que me iban diciendo contestarles y enriquecer el sketch, llevaba el ritmo de mi trabajo, a veces llegaba a estar más de una hora en el escenario [...] Tampoco trabajé en la televisión porque no me dejaban decir lo que yo quería, el cine y la televisión están muy condicionados a la censura [...] Pienso que por eso no triunfé en el cine como en la carpa, ni me gustaron estas cositas de la televisión, no oigo las risas, no hay reacciones; ahí en la carpa hay contacto, hay participación. ${ }^{287}$

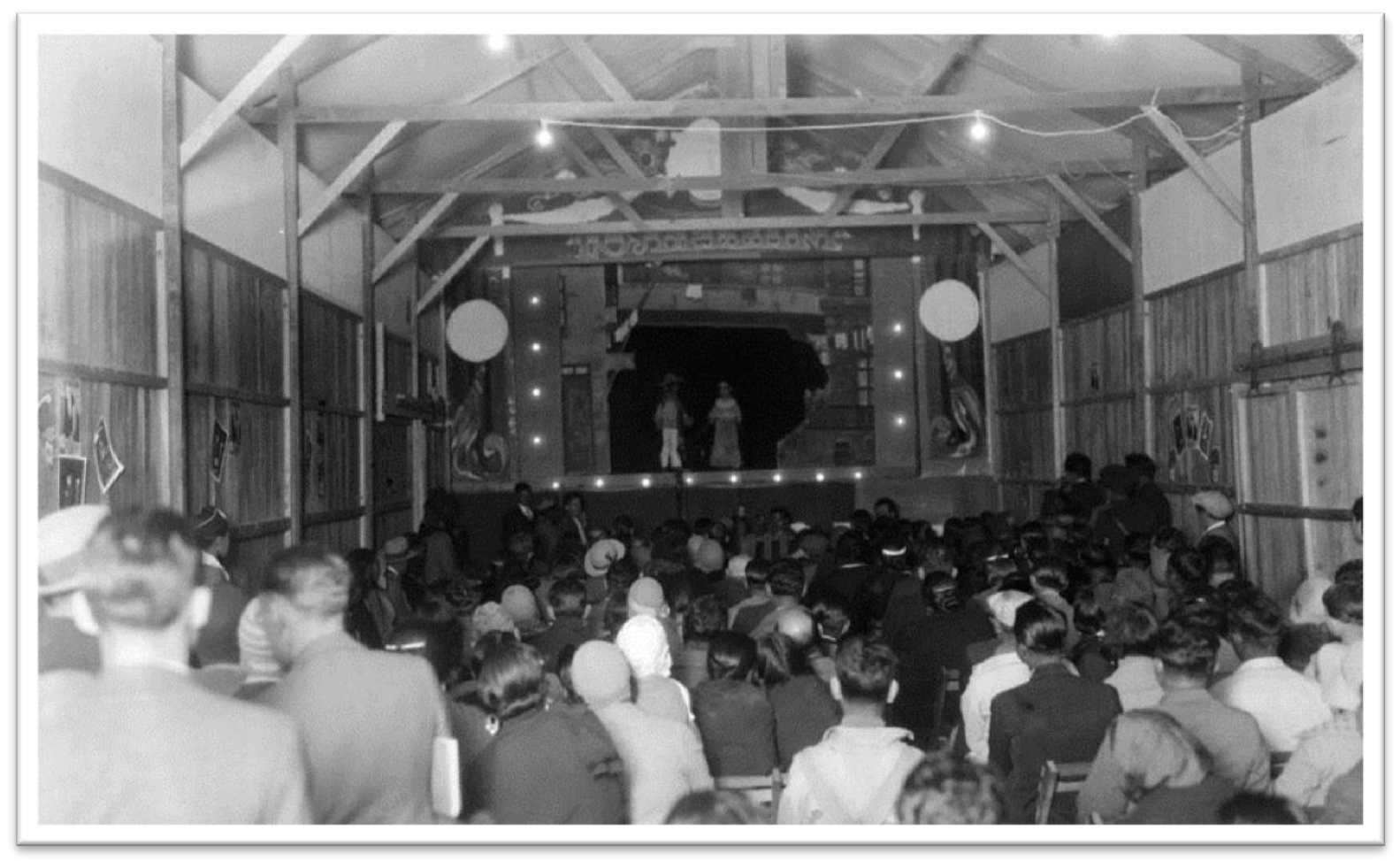

La relación público-actor fue desapareciendo con el radio, el cine y posteriormente la televisión.

Fuente: Fototeca INAH.

Lo que comenta Jesús Martínez Palillo es muy ilustrativo para dar cuenta del cambio al que se enfrentaron los cómicos al incursionar en el cine, el rompimiento de relación que se dio entre la sociedad y los actores, y la falta de libertad de expresión que sufrieron. Por su parte, Cantinflas en algún momento manifiesta que no abandonará el teatro, que siempre le hará falta a interacción con el público, cuestión que más tarde pudo suplantar con la fama.

\footnotetext{
${ }^{287}$ Sebastián Armando González de la Vega, op. cit., pág. 30.
} 
- Se dice que próximamente abandonará usted el teatro para dedicarse al cine por completo, ¿es cierto esto?

- No. Yo amo demasiado al teatro, desde luego que alternaré mis actividades teatrales con las cinematográficas. En la actualidad estoy terminando "Águila o sol" y para más tarde tengo otros dos contratos pendientes. En el cine, usted sabe, se gana mucho más que en el teatro, pero no sé... yo creo que a mí me haría mucha falta el público, los aplausos, así como aquí en la escena. ${ }^{288}$

Mientras rige la industria centralizada del espectáculo, el público se vuelve cada vez más sumiso y "los artistas pierden cuerpo, se descorporizan en la pantalla 0 en el cuadrante". ${ }^{289}$ Como argumentamos anteriormente, los gobiernos posrevolucionarios ganaron estabilidad, y con ello el control de los medios, los chistes políticos sólo serán permitidos postsexenalmente. "Lo lépero deja de ser una perspectiva para convertirse en un reducto, una reservación solapada como curiosidad lingüística en medio de un habla recientemente refinada según el modelo de la XEW" ${ }^{290}$ El actor que antes criticaba al gobierno, ahora se convierte nostálgicamente en un personaje pintoresco y folclórico utilizado para entretener a una población cada vez más cinevidente y radioescucha.

\footnotetext{
${ }^{288}$ Revista de revistas, 20 de marzo de 1938.

${ }^{289}$ Alfonso Morales, op. cit., pág. 113-114.

${ }^{290}$ Ibidem, pág. 112.
} 


\section{A MANERA DE CONCLUSIÓN}

Al final de este recorrido sobre el teatro popular en la primera mitad del siglo XX, podemos apuntar varios aspectos que están relacionados, desde cómo la ciudad y la vida cotidiana fueron cambiando en los diferentes momentos históricos, y su reflejo en el desarrollo del teatro popular y otros tipos de entretenimiento.

El teatro popular ofreció al público un espacio de encuentro comunitario para la canalización de sus manifestaciones políticas, que fueron reprimidas durante el Porfiriato a través de la falta de libertad de expresión, así como por el régimen posrevolucionario con la institucionalización de las diversiones y el surgimiento de la industria del entretenimiento.

Durante la "paz" porfiriana, la ciudad de México fue contemporánea del mundo, reflejado en las grandes obras, tecnología y arquitectura. Sin embargo, la sociedad no gozaba equitativamente de esta modernidad, existió una segregación territorial y cultural que se mostró claramente en el acceso a las diversiones públicas. El régimen tenía controlada la crítica política en cualquiera de sus manifestaciones, así como la moralidad y la higiene en los establecimientos. Cualquier tema político representado en el teatro debería necesariamente de enaltecer al régimen, de lo contrario era reprimido.

Los capitalinos tenían una amplia variedad de opciones de esparcimiento, no todas al alcance de cualquiera. Sin embargo lo que nos interesa es cómo fue que el teatro, que en su momento fue un espectáculo reservado a las clases acomodadas, pudo ser accesible a la clase popular a partir de la forma de vender las funciones por tandas, estrategia de los empresarios teatrales para obtener mayores ganancias, y reducto mediante el cual el teatro se volvió popular, lo cual sirvió como elemento para justificar el título de este trabajo.

La vida cotidiana y la estructura física de los teatros de élite distaban mucho del de las carpas, mientras en los primeros el ambiente era refinado y su estructura era muestra de la vanguardia arquitectónica, en las segundas no existía un control ni reglas establecidas de comportamiento y su precaria construcción manifestaba su carácter nómada y daba mala imagen a la ciudad. Ocasionalmente 
estas últimas características también eran atribuidas al pueblo, ya que se lo tachaba de pobre, que daba mal aspecto en la sociedad y era maleducado.

Uno de los argumentos más importantes de este trabajo se refiere al surgimiento del género político al final del gobierno de Porfirio Díaz, así todos los sucesos ocurridos a partir de entonces pudieron haber sido representados en el teatro de revista, cuya característica, como su nombre lo indica, era pasar revista a las principales noticias acontecidas, y de esta manera el teatro tuvo la función de entretener a la población y mantenerla informada. "Los personajes de la vida política, tanto personas como instituciones, dejaron de ser abstractos y adquirieron corporalidad en el teatro; personas de carne y hueso dieron vida a símbolos como el dinero, la política, la patria, el hambre, el gobierno". ${ }^{291}$ Por lo mismo, los autores siempre estuvieron al pendiente de los hechos y rápidamente escribían libretos, que al ser representados provocaban gran aceptación en el público, no sin sentir el rigor de la autoridad y en muchos casos ser reprimidos. El mismo teatro de revista fue importante para algunos políticos que buscaban hacerse propaganda, sin embargo los autores debían tener cuidado, porque los cambios de gobierno llegaban de forma muy rápida, y si en su momento apoyaron a algún personaje, a la caída de éste sufrían represalias por el nuevo régimen, como fue el caso de Felipe G. Elizondo y Leopoldo El cuatezón Beristáin, entre otros.

Prácticamente todos los políticos desde el inicio de la Revolución fueron parodiados en el teatro de revista. Sólo el gobierno de Lázaro Cárdenas volvería a ser enaltecido, mientras él mismo apoyaba al teatro de carpas y al género de revista al dejarle entrar al Palacio de Bellas Artes. Característica que también tiene relación con la consolidación del aparato corporativo y el control sobre las diversiones.

Otro argumento fue que los actores de carpa compartieron personalidades en común que los llevó a ganarse el gusto de la gente, ya que caracterizaban a personajes del ambiente arrabalero que eran parte de la vida cotidiana de la mayoría de los espectadores. Se podría decir que el público se sentía representado por el artista, y este se convertía en especie de héroe al criticar a los

${ }^{291}$ Carlos Pérez Bazán, op. cit., pág. 52. 
personajes políticos del gobierno en turno. El objetivo de muchos de los actores y autores fue crear una conciencia política en sus espectadores, y en diversas ocasiones fueron reprimidos por las autoridades.

La relación entre el público y los actores es muy importante para entender el carácter popular del teatro, característica sólo equivalente con la lucha libre, ya que la participación del público era fundamental para la realización del espectáculo. El gritarle al actor o el aventarle objetos correspondía a su aplauso y al éxito de las obras.

Desde la década de 1930, tanto el teatro de revista como las carpas empezaron su decadencia. Por una parte debido a la consolidación del Estado y la estabilidad política de los dirigentes, con su correspondiente control de las diversiones, cuestión que está relacionada también con la aglomeración de los trabajadores del entretenimiento en el sistema corporativo y de cómo los gobiernos posrevolucionarios canalizaron la cultura popular para convertirla poco a poco en una industria del entretenimiento, que claramente se despolitiza, adquiere una gran capacidad de difusión por medios radiofónicos, y después televisivos, con fuerte penetración en la sociedad.

Asimismo la creciente industrialización y la urbanización de la ciudad fue fatal para las carpas establecidas en las plazuelas, sólo el teatro de revista podía ser representado en los recintos establecidos, sin embargo este género ya no era del gusto de la población, ya que se prefería el teatro de variedades y la revista romántica, sin mencionar que la radio y el cine también fueron desplazándolo.

Otro factor que llevó a la decadencia del teatro político fue que los autores y artistas querían llevar una relación pacífica con el gobierno, por lo que se abstuvieron de realizar la menor crítica al régimen ya consolidado. Mientras tanto el público se volvía más sumiso y prefería otro tipo de diversiones.

Con el auge de la radio y el cine, el teatro de revista decayó y la relación entre el público y los actores se perdió, podían seguir escuchando sus chistes, en gran medida despolitizados, en la radio y viéndolos en el cine, pero ya no podían participar en el espectáculo. Incluso la población ya no disfrutaba de manera 
comunitaria los espectáculos ya que la radio fue un medio que ofrecía el esparcimiento individual dentro de los hogares.

Por otra parte, y como argumentamos en otra de nuestras hipótesis, muchos de los actores de carpa adquirieron mayor prestigio en el cine. Otros como Palillo, no alcanzaron el éxito, incluso este personaje no gustó del cine porque no permitía la relación público-actor que era lo que daba vida al espectáculo, aunado a la falta de libertad para manifestar sus ideas políticas en el medio.

Asimismo la imagen arrabalera de los personajes de carpa siguió siendo utilizada en el cine, pero ahora aprovechado por el régimen. El público siguió viéndose representado en ellos, y el Estado bien pudo mantener el control y usar a estos personajes para que de una manera analógica el pueblo se riera de sí mismo. 


\section{BiBLIOGRAFÍA}

Archivo Histórico del Distrito Federal.

Archivo General de la Nación.

Archivo de la palabra $\mathrm{PHO} / 2 / 86$, Instituto Mora.

Centro Nacional de Investigación Teatral Rodolfo Usigli (CITRU).

Fototeca Nacional- INAH.

Diarios: El Imparcial, El mundo ilustrado, El Tiempo y Revista de revistas.

Barbosa Cruz, Mario, El trabajo en las calles. Subsistencia y negociación política en la ciudad de México a comienzos del siglo XX. El Colegio de México, UAM-C, México, 2008.

, "La ciudad de México durante la Revolución. Miradas desde la historiografía reciente", en Leyva, Gustavo et al. (coordinadores), Independencia y Revolución: pasado, presente y futuro, UAM-FCE, México, 2010, pp. 292-312.

, "La ciudad: crecimiento urbano y población", en Barbosa Cruz, Mario y González, Salomón (coordinadores), Problemas de la urbanización en el Valle de México, 1810-1910. Un homenaje visual en la celebración de los centenarios, UAM, México, 2009, pp. 173-190.

BARTRA, Roger, La jaula de la melancolía, Grijalbo, México, 1987.

BerRA Stoppa, Érica, La expansión de la ciudad de México y los conflictos urbanos, 1900-1930, El Colegio de México, México, 1982.

BERTACCINI, Tiziana, Ficción y realidad del héroe popular, conAcUltA, México, 2001.

BeEZley, William H., La identidad nacional mexicana: la memoria, la insinuación y la cultura popular en el siglo XIX, México, El colegio de la frontera norte-El colegio de San Luis- El colegio de Michoacán AC, México, 2008. , Judas en el Jockey Club, México, El colegio de San LuisCIESAS, 2010.

Blanco, José Joaquín, Ciudad de México. Espejos del siglo xx, CONACULtA-INAHEra, México, 1998. 
Bravo Saldaña, Yolanda, "De la carpa al cine", en Mexicanísimo. Abrazo de una pasión, año 3, no. 29.

CONTRERAS Soto, Eduardo, "A caballo entre dos estilos. Las dramaturgias mexicanas y sus vidas escénicas en los inicios del siglo XX", en Olguín, David (coordinador), Un siglo de teatro en México, CONACULTA-FCE, México, 2011, pp. 17-39.

De Gortari, Hira y Hernández, Regina, Memoria y encuentros: La ciudad de México y el DF (1824-1928), tomo III, DDF-Instituto Mora, México, 1988.

De los Reyes, Aurelio, Los orígenes del cine en México (1896-1900), FCE, México, 1983.

, Cine y sociedad en México, 1896-1930. Vol. I. Vivir de sueños (1896-1920), IEE-UNAM, México, 1993.

, Cine y sociedad en México, 1896-1930. Vol. II. Bajo el cielo de México (1920-1924), IEE-UNAM, México, 1993.

, iTercera llamada, tercera! Programas de espectáculos ilustrados por José Guadalupe Posada, Instituto Cultural de Aguascalientes, México, 2005.

De Maria y Campos, Armando, El teatro de género chico en la Revolución Mexicana, ConACULTA, México, 1996.

, Las tandas del principal, Diana, México, 1989.

De OlavarRía Enrique y Ferrari, Reseña histórica del teatro en México. 1538-1911, volumen v, México, Porrúa, 1961.

DíAz Alfaro, Salomón, "El Distrito Federal mexicano. Breve historia constitucional", en María del Carmen Álvarez Castro (coordinadora), Estudios Jurídicos en torno a la Constitución mexicana de 1917 en su septuagésimo quinto aniversario, IIJ-UNAM, México, pp. 198-217.

DoWLING, John, "Teatro cómico y lo cómico en el teatro español de la posguerra", en Hispania, vol. 60, no. 4, diciembre, 1977, pp. 899-906.

DUEÑAS, Pablo, Las divas en el teatro de revista mexicano, Asociación mexicana de estudios fonográficos, A.C., México, 1994. 
y Flores y Escalante, Jesús, "Teatro de revista (1904-1936)" en

Teatro mexicano. Historia y dramaturgia, volumen XX, México, CONACULTA, 1995.

García Cubas, Antonio, El libro de mis recuerdos, Patria, México, 1945.

Garza, Gustavo, La urbanización de México en el siglo XX, El Colegio de México, México, 2005.

GonZÁlez de la Vega Alcántara, Sebastián Armando, Jesús Martínez Rentería "Palillo" en el periodo 1952-1964, tesis para optar por el grado de Licenciado en Ciencias de la Comunicación, UNAM, México, 2001.

Granados, Pedro, Carpas de México. Leyendas, anécdotas e historias del teatro popular, Editorial Universo, México, 1984.

GutiéRREZ Nájera, Manuel, "Las tandas del principal”, en Obras 111, Crónicas y artículos sobre teatro-I (1876-1880), UNAM, México, 1974, pp. 302-305.

HiRIART, Hugo, Circo callejero, Conaculta-INAH-era, México, 2002.

JIMÉNEZ Gómez, Juan Ricardo, “Diversiones, fiestas y espectáculos en Querétaro”, en Staples, Anne (coordinadora), Historia de la vida cotidiana en México: tomo IV: Bienes y vivencias. El siglo XIX, El Colegio de México-FCE, México, 2005, pp. 333-366.

LEAL, Juan Felipe, et. al., Anales del cine en México, 1895-1911. Volumen 5: 1899: ¡A los barrios y a la provincia!, Voyeur, México, 2003.

LóPEZ Rangel, Rafael, La planificación y la ciudad de México 1900-1940, UAM-A, México, 1993.

LORENZO Río, María Dolores, "Entre el vicio y el beneficio. Segregación social y espacios de entretenimiento en la Ciudad de México, 1810-1910", en Barbosa, Mario y González, Salomón (coordinadores), Problemas de la urbanización en el Valle de México, 1810-1910. Un homenaje visual en la celebración de los centenarios, UAM, México, 2009, pp. 227-262.

LoYo Bravo, Engracia, "El México revolucionario", en Escalante Gonzalbo, Pablo, et al., Historia mínima de la vida cotidiana en México, México, El Colegio de México, 2010, pp. 185-244. 
MARTínez Marín, Lucio Ricardo, Del teatro a la Alameda. Diversiones públicas en la Ciudad de México durante el Porfiriato, Tesis de licenciatura en Historia, UAM-I, México, 1991.

MARTíneZ, Claudia, El género chico o teatro de revista en nuestro país y su historia. Tesis para obtener el título de Actuación, Escuela de Arte Teatral, CNA, México, 1988.

MARTínEZ, Romina, “¡Corre...! ¡Va a comenzar la tanda...! Un acercamiento a la diversión carpera en Guadalajara, 1920-1940", en Takwa, no. 9, primavera 2006, pp. 109-126.

Merlín, Socorro, Vida y milagros de las carpas. La carpa en México, 1930-1950, INBA, México, 1995.

, Teatro y política en la obra de Marcelino Dávalos, INBA, México, 2011.

MEYER, Lorenzo, "La institucionalización del nuevo régimen", en Historia general de México, El Colegio de México, México, 2000, pp. 823-879.

MIQUEL, Ángel, Disolvencias. Literatura, cine y radio en México (1900-1950), FCE, México, 2005.

MiRANDA, Jorge (compilador), Del racho al bataclán. Cancionero del teatro de revista, 1900-1940, México, Museo Nacional de Culturas Populares, 1984.

MonsIvÁls, Carlos, Escenas de pudor y liviandad, Grijalbo, México, 1981. , Historia mínima. La cultura mexicana en el siglo XX, El Colegio de México, México, 2010.

, "Notas sobre la cultura mexicana en el siglo Xx", en Historia general de México, El Colegio de México, México, 2000, pp. 957-1 076.

Morales, Alfonso, El país de las tandas. Teatro de Revista, 1900-1940, CONACULTA, México, 1984.

Orozco José, Clemente, Autobiografía de José Clemente Orozco, Era, México 1970.

OrTiz Bullé Goyri, Alejandro, "Confrontaciones y coexistencias en la renovación teatral mexicana en la primera década del México posrevolucionario (19201931)", en Franco, Israel y Escobar Delgado, Antonio (coordinadores), El 
teatro de Ahora: un primer ensayo del teatro político en México, CONACULTA, México, 2011, pp. 265-284.

, "Orígenes y desarrollo del teatro de revista en

México (1869-1953)", en Olguín, David (coordinador), Un siglo de teatro en México, CONACULTA-FCE, México, 2011, pp. 40-53.

PÉREZ Bazán, Carlos, "La identidad nacional en el teatro popular durante la primera década del siglo XX", en Béjar, Raúl y Rosales, Silvano Héctor (coordinadores) La identidad nacional mexicana en las expresiones artísticas. Estudios históricos y contemporáneos, UNAM-Plaza y Valdés, México, 2008.

PÉREZ Montfort, Ricardo, "El pueblo y la cultura. Del Porfiriato a la Revolución", en Raúl Béjar y Héctor González (coordinadores), La identidad nacional mexicana como problema político y cultural. Nuevas miradas, UNAM, México, 2005.

, Cotidianidades, imaginarios y contextos: ensayos de historia y cultura en México, 1850-1950, CIESAS, México, 2008. , Expresiones populares y estereotipos culturales en México. Siglos XIX y XX. Diez ensayos, CIESAS, México, 2007.

Piccato, Pablo, Ciudad de sospechosos: crimen en la ciudad de México, 19001931, CIESAS-FONCA, México, 2010.

, "Altibajos de la esfera pública en México, de la dictadura republicana a la democracia corporativa. La era de la prensa", en Leyva, Gustavo et al. (coordinadores), Independencia y Revolución: pasado, presente y futuro, UAM-FCE, México, 2010, pp. 240-291.

PULIDo Llano, Gabriela, "Empresarias y tandas", en Bicentenario. El ayer y hoy de México, volumen 2, no. 6, 2009, Instituto Mora, México, 2009, pp. 14-21. , Mulatas y negros cubanos en la escena mexicana, 1920-1950, INAH, México, 2010.

ReYes de la Maza, Luis, 100 años de teatro en México (1810-1910), SEP, México, 1972. , Circo, maroma y teatro, unam, México, 1985. 
RODRIGIEZ Kuri, Ariel, "Desabasto, hambre y respuesta política, 1915", en Illades, Carlos y Rodríguez Kuri, Ariel (compiladores), Instituciones y ciudad. Ocho estudios históricos sobre la ciudad de México, Ediciones Uníos, México, 2000, pp. 133-166.

SABINE Schlickers, Ana Luengo, "'A tu patria mueves guerra...' Dramas mexicanos de la independencia" en Leyva, Gustavo et al. (coordinadores), Independencia y Revolución: pasado, presente y futuro, UAM-FCE, México, 2010, pp. 313-348.

SeVILLA, Amparo, Los templos del buen bailar, conAcUltA, México, 2003.

SPECKMAN Guerra, Elisa, "De barrios y arrabales: entorno, cultura material y quehacer ciudadano (ciudad de México, 1890-1910)", en De los Reyes, Aurelio (coordinador), Historia de la vida cotidiana en México: tomo v. Siglo XX, campo y ciudad, Volumen 1, El Colegio de México, FCE, México, 2006, pp. 17-48.

StAPles, Anne, "El siglo XIX", en Escalante Gonzalbo, Pablo, et al., Historia mínima de la vida cotidiana en México, México, El Colegio de México, 2010, pp. 119-184.

SUSAN E., Bryan, "Teatro popular y sociedad durante el Porfiriato", en Historia Mexicana, Vol. 33 no. 1, julio-septiembre, 1983, El Colegio de México, pp. 130-169.

VIQUEIRA Albán, Juan Pedro, ¿Relajados o reprimidos? Diversiones públicas y vida social en la ciudad de México durante el Siglo de las Luces, México, FCE, 1987. 
TEATRO POPULAR EN LA CIUDAD DE MEXICO EN LA PRIMERA

MITAD DEL SIGLO XX

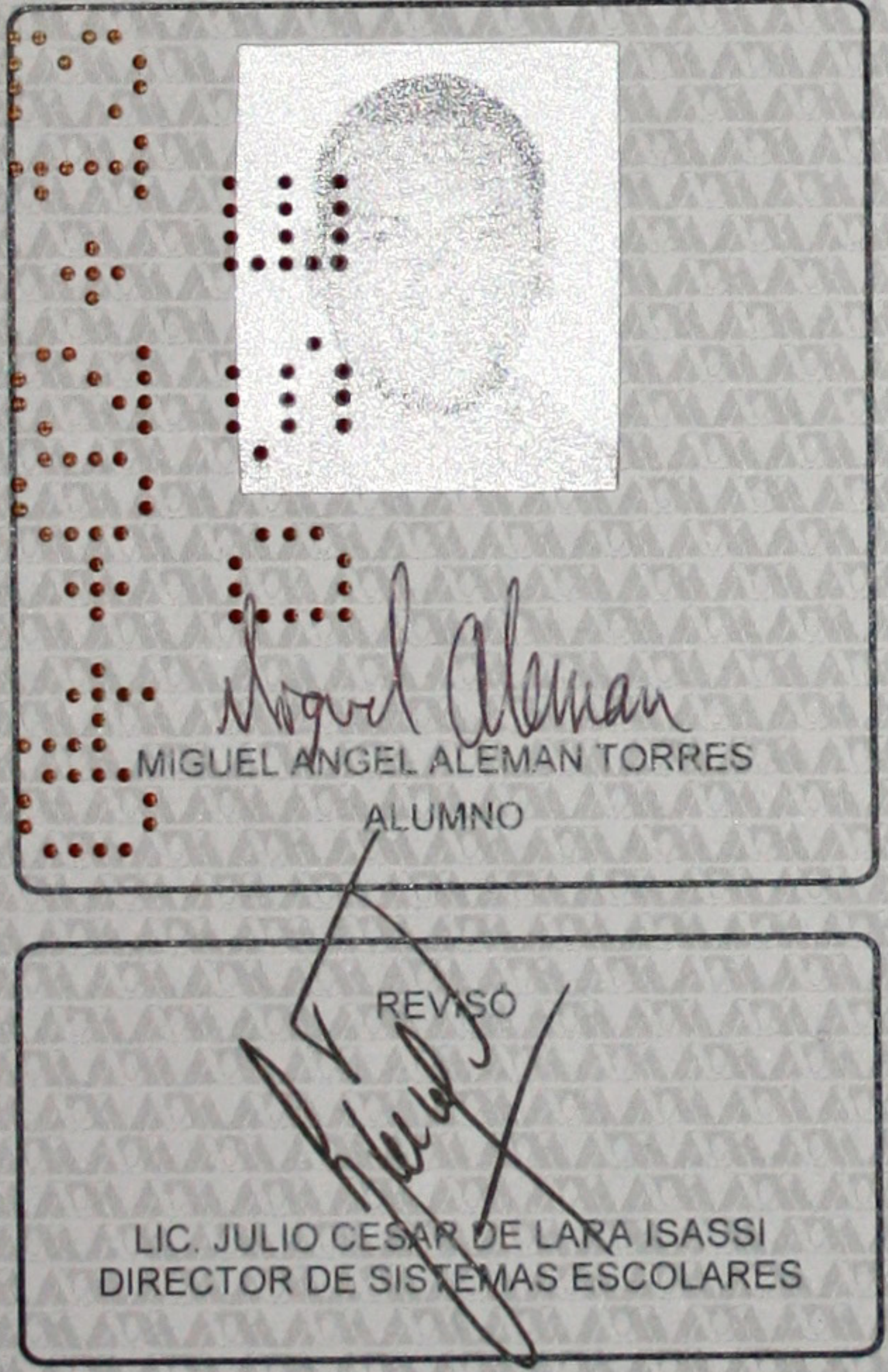

Acto continuo, el presidente del jurado comunicó al interesado el resultado de la evaluación $y$, en caso aprobatorio, le fue tomada la protesta.

En México, D.F., se presentaron a las 9:00 horas del día 29 del mes de enero del año 2013 en la Unidad Iztapalapa de la Universidad Autónoma Metropolitana, los suscritos miembros del jurado:

DR. FEDERICO LAZARIN MIRANDA

DR. MARIO BARBOSA CRUZ

DR. CARLOS ILLADES AGUIAR

Bajo la Presidencia del primero y con carácter de Secretario el último, se reunieron para proceder al Examen de Grado cuya denominación aparece al margen, para la obtención del grado de:

MAESTRO EN HUMANIDADES (HISTORIA)

DE: MIGUEL ANGEL ALEMAN TORRES

y de acuerdo con el artículo 78 fracción III del Reglamento de Estudios Superiores de la Universidad Autónoma Metropolitana, los miembros del jurado resolvieron:

\section{APROBAR}

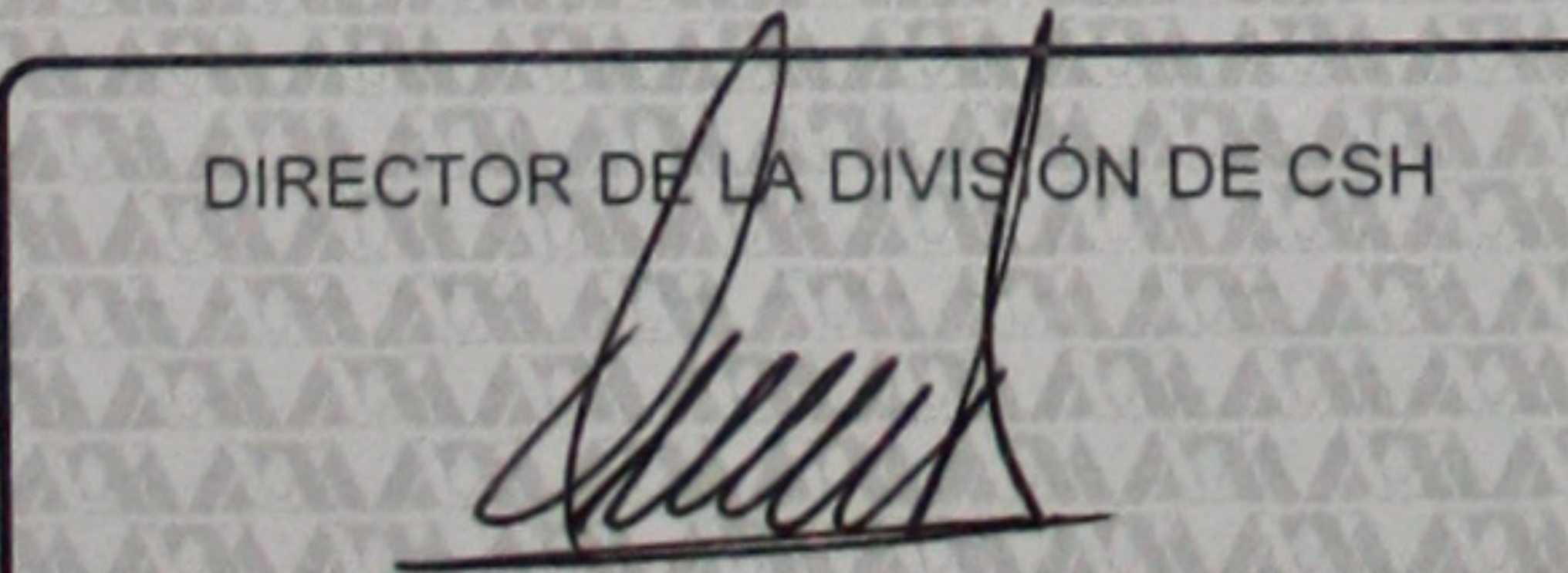

DR. JOSE OCTAVIO NATERAS DOMINGUEZ

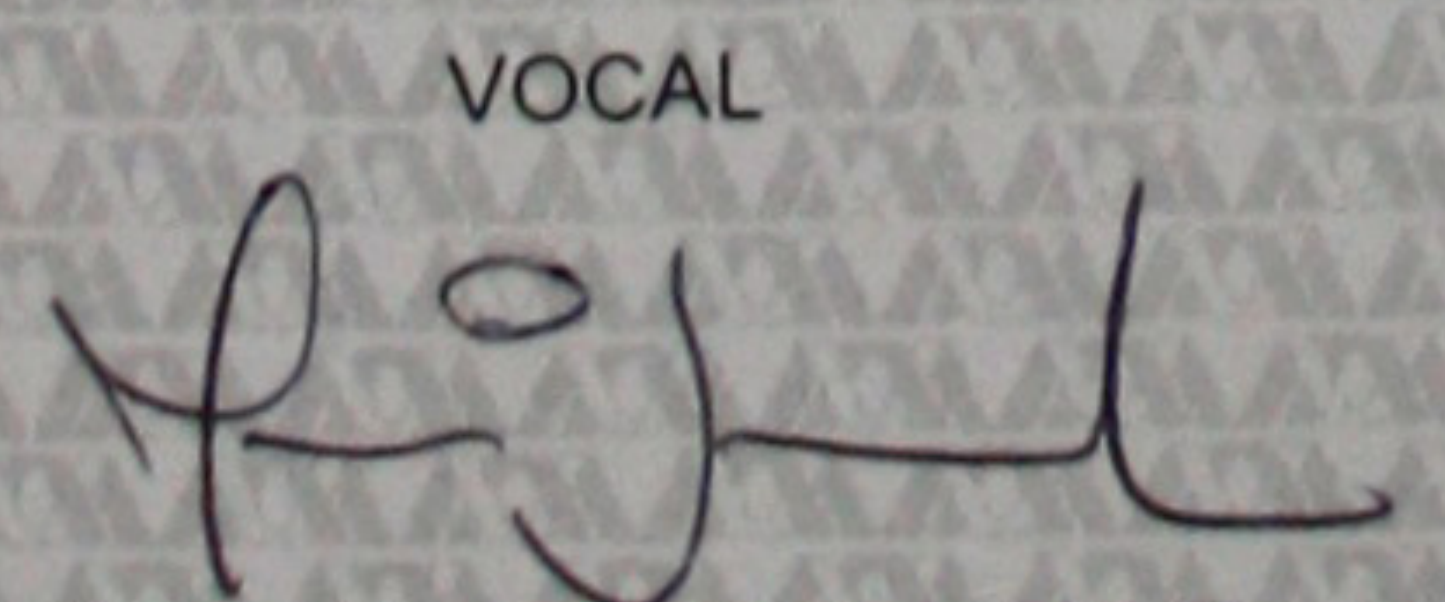

DR. MARIO BARBOSA CRUZ

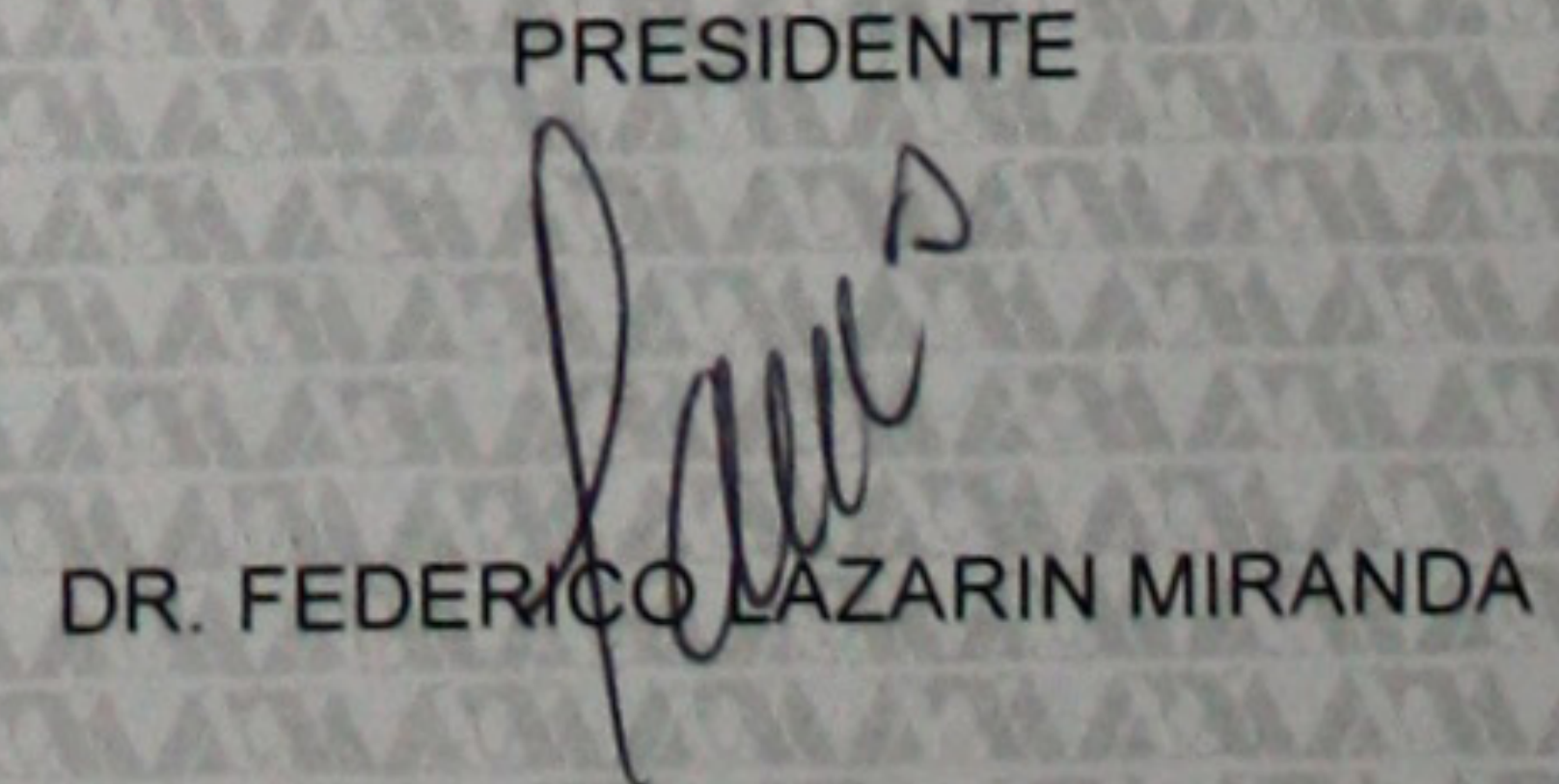

SECRETARIO

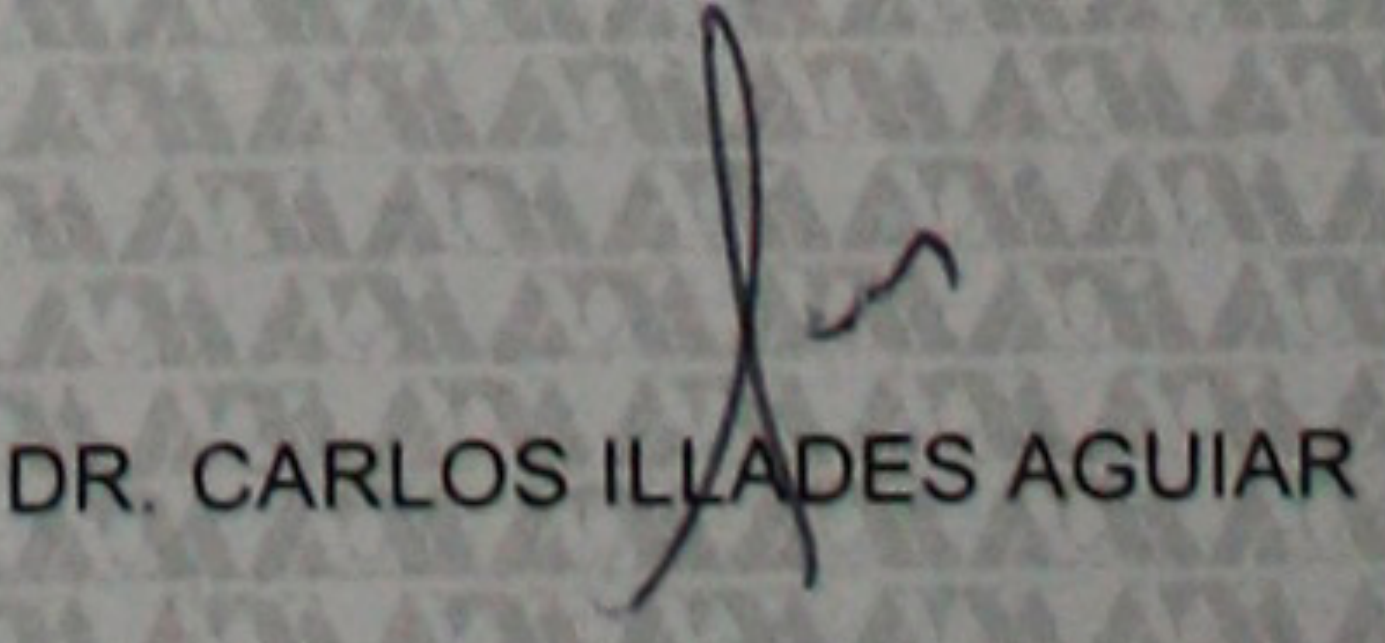

